Florida International University FIU Digital Commons

9-13-2010

\title{
Assessment of Submerged Vegetation as Indicators of Irgarol Contamination
}

Melissa V. Fernandez

Florida International University,mfern041@fiu.edu

DOI: $10.25148 /$ etd.FI10121001

Follow this and additional works at: https://digitalcommons.fiu.edu/etd

Part of the Analytical Chemistry Commons, Biochemistry Commons, and the Environmental Sciences Commons

\section{Recommended Citation}

Fernandez, Melissa V., "Assessment of Submerged Vegetation as Indicators of Irgarol Contamination" (2010). FIU Electronic Theses and Dissertations. 328.

https://digitalcommons.fiu.edu/etd/328

This work is brought to you for free and open access by the University Graduate School at FIU Digital Commons. It has been accepted for inclusion in FIU Electronic Theses and Dissertations by an authorized administrator of FIU Digital Commons. For more information, please contact dcc@fiu.edu. 


\title{
FLORIDA INTERNATIONAL UNIVERSITY
}

Miami, Florida

\section{ASSESSMENT OF SUBMERGED VEGETATION AS INDICATORS OF IRGAROL CONTAMINATION IN SOUTH-EAST FLORIDA}

\author{
A thesis submitted in partial fulfillment of the \\ requirements for the degree of \\ MASTER OF SCIENCE \\ in \\ CHEMISTRY \\ by
}

Melissa Victoria Fernandez

2010 
To: Dean Kenneth Furton

College of Arts and Sciences

This thesis, written by Melissa Victoria Fernandez, and entitled Assessment of Submerged Vegetation as Indicators of Irgarol Contamination in South-east Florida, having been approved in respect to style and intellectual content, is referred to you for judgment.

We have read this thesis and recommend that it be approved.

David Chatfield

Rudolf Jaffé

Piero Gardinali, Major Professor

Date of Defense: September 13, 2010

The thesis of Melissa Victoria Fernandez is approved.

\begin{tabular}{r}
$\begin{array}{r}\text { Dean Kenneth Furton } \\
\text { College of Arts and Sciences }\end{array}$ \\
\hline Interim Dean Kevin O'Shea \\
University Graduate School
\end{tabular}

Florida International University, 2010 


\section{DEDICATION}

I dedicate this thesis to my family: Gilberto, Martha, Lisette and Julian Fernandez. Without their patience, understanding, support, and most of all love, the completion of this work would not have been possible. 


\section{ACKNOWLEDGMENTS}

I wish to than the members of my committee for their patience, support and good humor. Dr. Piero Gardinali was particularly helpful in guiding me towards independent research and detailed methodology. I thank him for confidence in my abilities to learn a new field of science, independently perform the research and to complete this degree with excellence.

I also thank my sister, Lisette Fernandez, for lending her Autocad skills in Figure 4.1.

Ciba Specialty Chemical provided partial funding for this work. 


\title{
ABSTRACT OF THE THESIS \\ ASSESSMENT OF SUBMERGED VEGETATION AS INDICATORS OF IRGAROL CONTAMINATION IN SOUTH-EAST FLORIDA
}

\author{
by
}

\author{
Melissa Victoria Fernandez
}

Florida International University, 2010

Miami, Florida

\section{Professor Piero Gardinali, Major Professor}

Irgarol 1051 is a common antifoulant toxic to certain marine organisms. Submerged aquatic vegetation (SAV) are exposed to this herbicide when it leaches into the marine environment from painted structures, making SAVs ideal candidates to function as sentinel indicator of contamination. In the initial stage of this study, Coconut Grove and Key Largo Harbor were assessed for environmental exposure to Irgarol. Water, sediment and SAVs were collected, the latter two subject to automated solid phase extraction, and all samples analyzed by GC/MS-SIM for Irgarol and its metabolite, M1. Of the vegetation analyzed, Halodule and Syringodium had the highest capacity to bioaccumulate Irgarol and M1. The root system and leaf contributed negligibly and significantly, respectively, to Irgarol uptake. In the final stage, a transplant between Coconut Grove and Chicken Key showed that the biota Thalassia and Halodule were able to uptake and depurate Irgarol, respectively, over a period of 30 days. 


\section{TABLE OF CONTENTS}

CHAPTER

PAGE

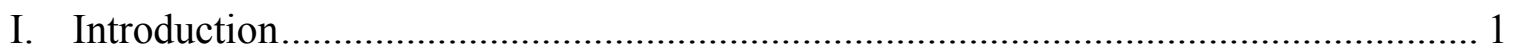

1.1. Irgarol 1051: A Review ………………………….................................. 1

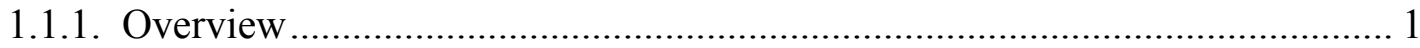

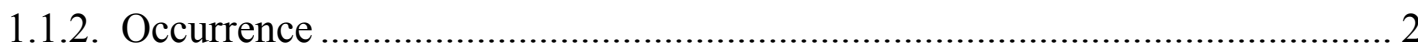

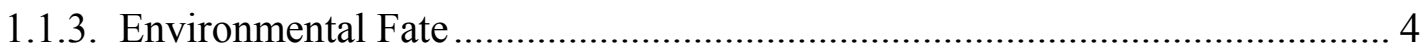

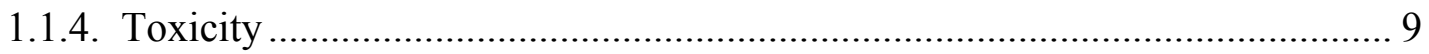

1.2. South Florida Submerged Aquatic Vegetation ……......................................... 10

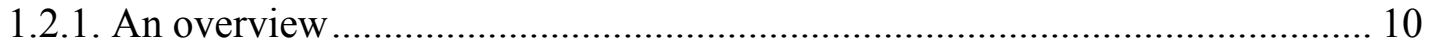

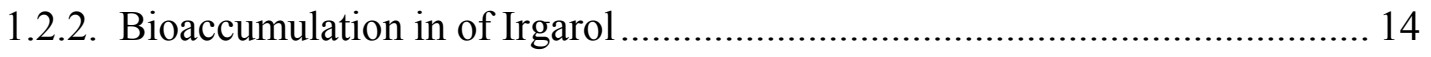

1.3. Scope and Objectives of the Study .................................................................. 17

II. Occurrence of Irgarol, M1 and M3 in South Florida............................................. 18

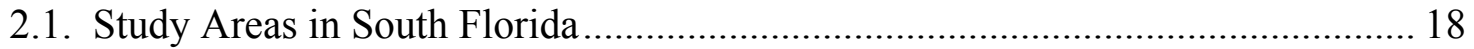

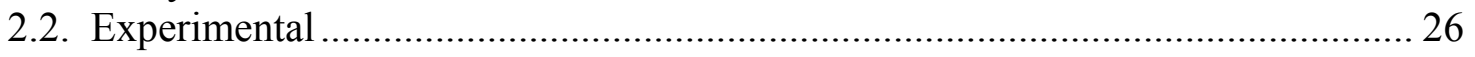

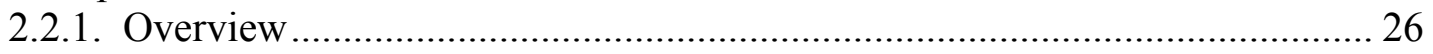

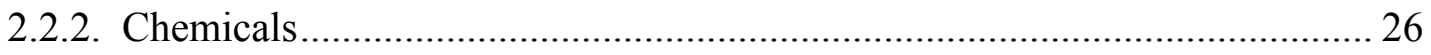

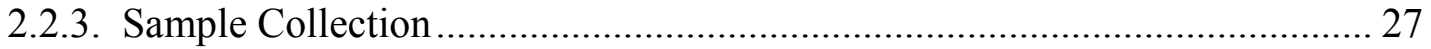

2.2.3.1. Surface Water Samples ...................................................................... 27

2.2.3.2. Sediment Samples ............................................................................... 27

2.2.4. Sample Extraction............................................................................. 28

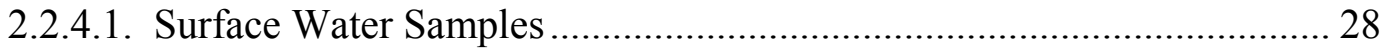

2.2.4.2. Sediment Samples ........................................................................... 28

2.2.4.3. Solid Phase Extraction of Sediment Samples ......................................... 29

2.2.4.3.1. Manual Solid Phase Extraction........................................................ 29

2.2.4.3.2. Automated Solid Phase Extraction ................................................... 30

2.2.5. Sample Analysis by GC-MS .................................................................. 30

2.2.6. Method Performance and Statistical Analysis .............................................. 32

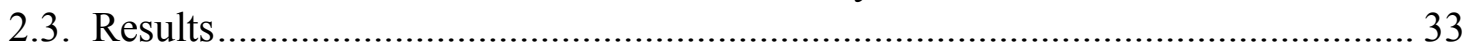

2.3.1. Solid Phase Extraction Method Comparison ............................................... 33

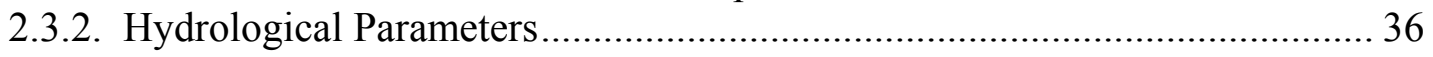

2.3.2.1. Miami River ............................................................................. 38

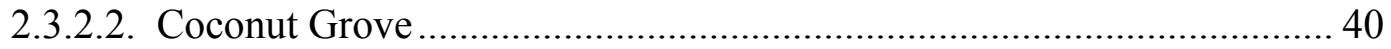

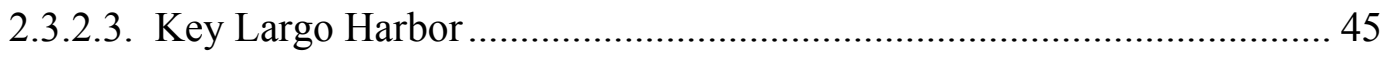

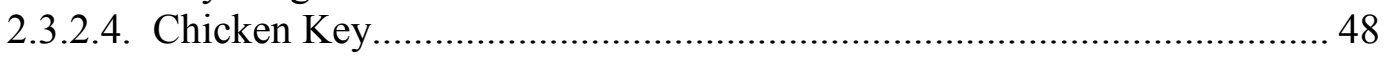

2.3.2.5. Comparison between locations ............................................................. 49

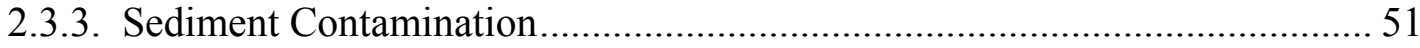

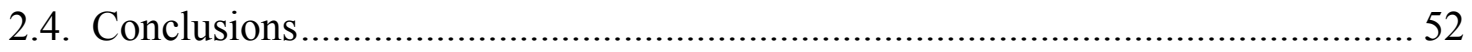

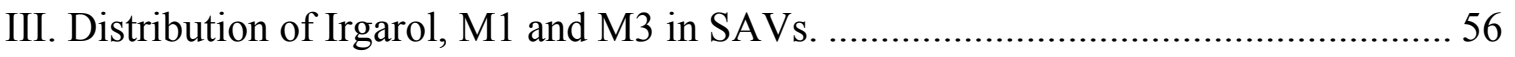

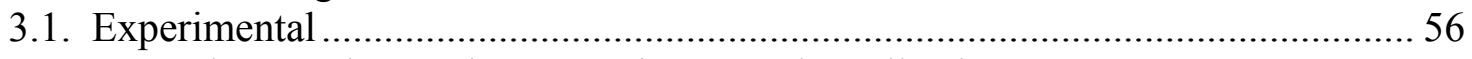

3.1.1. Submerged Aquatic Vegetation Sample Collection ....................................... 56 
3.1.2. Surface Water Aquatic Vegetation Sample Collection.................................... 57

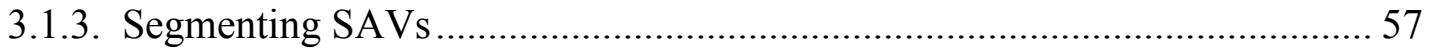

3.1.4. Submerged Aquatic Vegetation Sample Extraction ...................................... 57

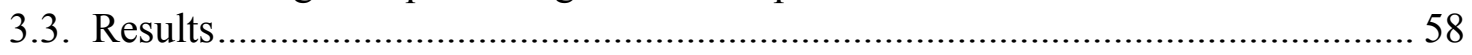

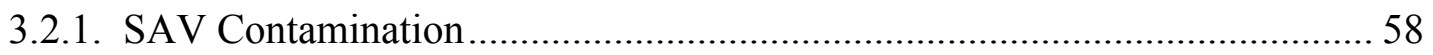

3.2.2. Surface Aquatic Vegetation Contamination ................................................. 68

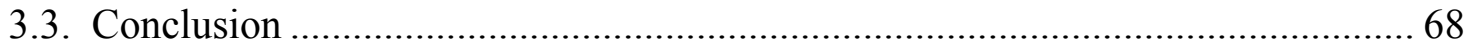

IV. Ability of SAV to Uptake and Depurate Irgarol.................................................... 70

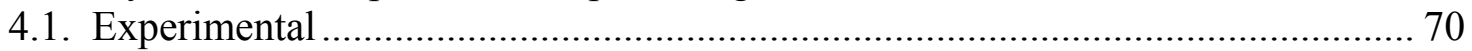

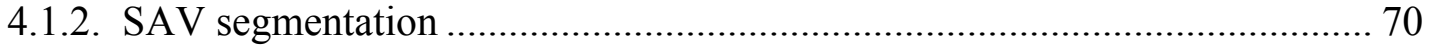

4.1.1. Transplant of Thalassia and Halodule …………....................................... 70

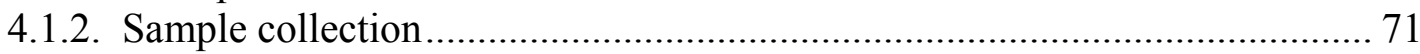

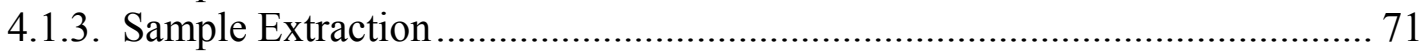

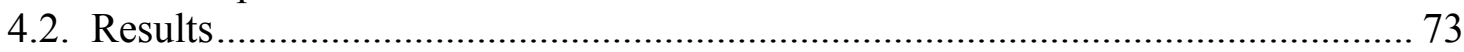

4.2.1. Distribution in Aquatic Vegetation Tissue …………................................... 73

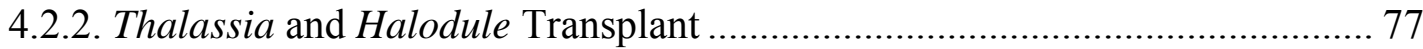

4.2.3. Estimating total Irgarol accumulated in SAV biomass, Biscayne Bay ........... 81

4.2.4. Estimating percent Irgarol accumulated from the environment....................... 83

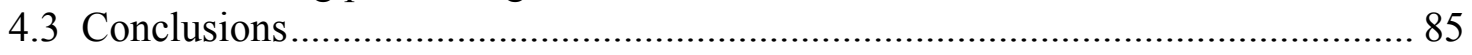

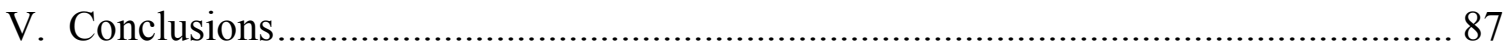

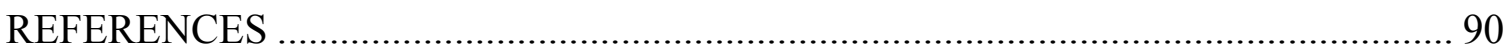

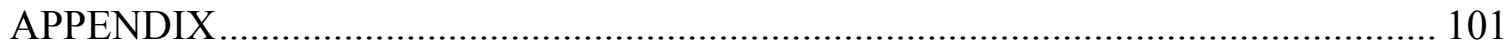




\section{LIST OF TABLES}

TABLE

PAGE

Table 1.1 Scheme for evaluating the bioaccumulation tendency of a compound.... 15

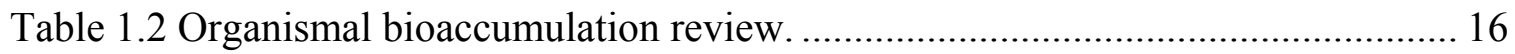

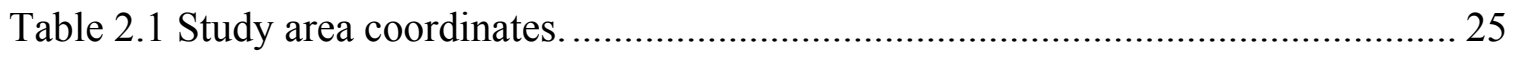

Table 2.2 SIM mass table for analysis............................................................... 31

Table 2.3 Recoveries of target compounds in fortified blanks................................... 33

Table 2.4 Recoveries of fortified blanks, SPE method............................................. 34

Table 2.5 Recovery in fortified blanks, automated SPE method................................ 35

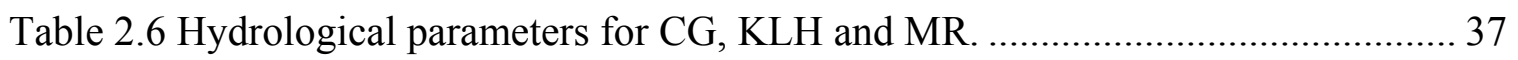

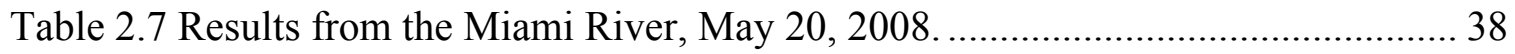

Table 2.8 Summary of results from CG surface waters.......................................... 43

Table 2.9 Summary of results from KLH surface waters. ......................................... 43

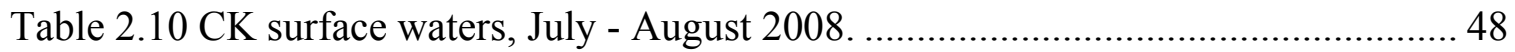

Table 2.11 Sediment concentrations (ng/g), CG and KLH...................................... 51

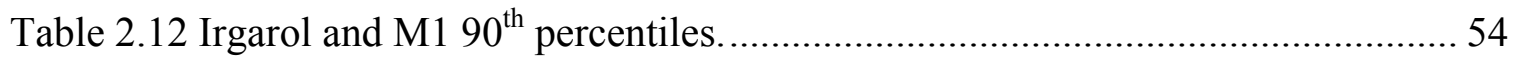

Table 2.13 Irgarol and M1 estimated in water column........................................... 55

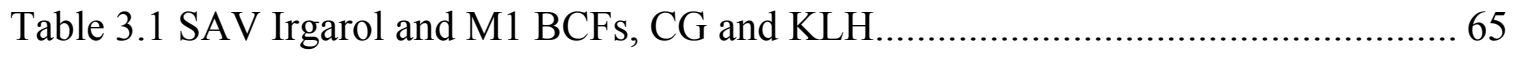

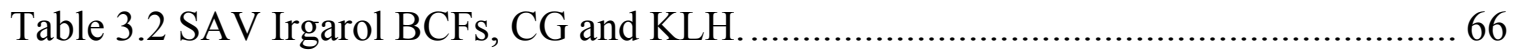

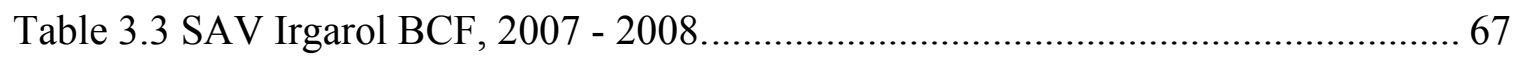

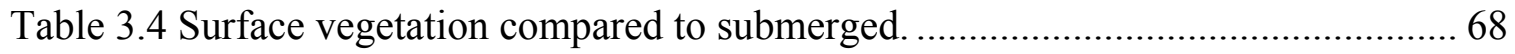

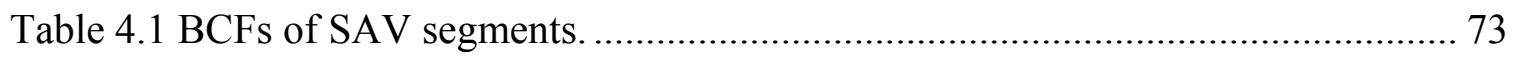

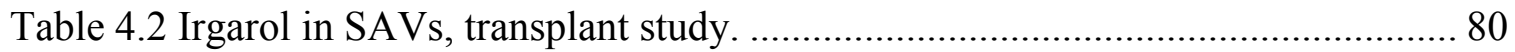




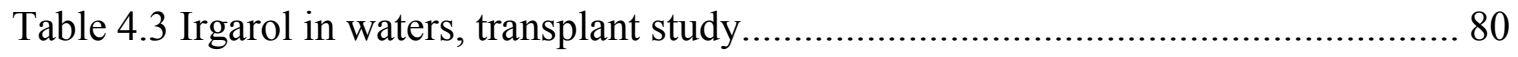

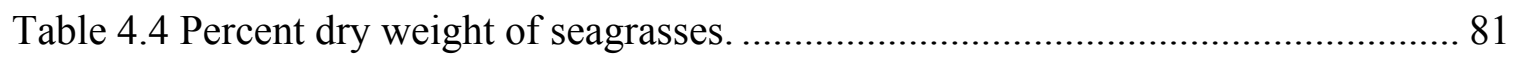

Table 4.5 Estimation of Irgarol in SAV biomass.................................................... 82

Table 4.6 Estimation of percent Irgarol accumulated.............................................. 84 


\section{LIST OF FIGURES}

FIGURE

PAGE

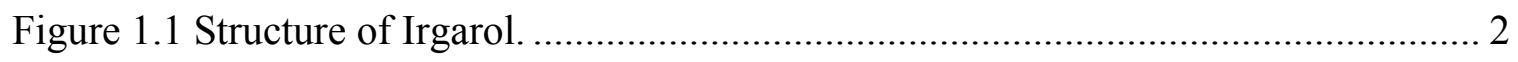

Figure 1.2 Structure of Irgarol metabolite M1........................................................ 5

Figure 1.3 Structure of Irgarol metabolite M2 ...................................................... 6

Figure 1.4 Structure of Irgarol metabolite M3 ...................................................... 7

Figure 1.5 Summary of the Irgarol degradation pathway and metabolite formation......... 8

Figure 1.6 Three major marine angiosperms found in south-Florida coastal waters........ 12

Figure 1.7 Four macroalgae present in south-Florida coastal waters. ........................... 13

Figure 2.1 Study areas in Southeastern Florida................................................... 21

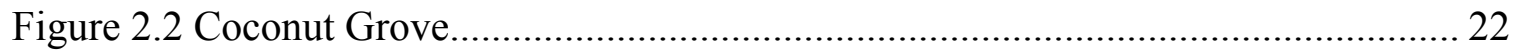

Figure 2.3 Miami River watercraft storage trends. ................................................ 23

Figure 2.4 Key Largo Harbor watercraft storage trends. ......................................... 24

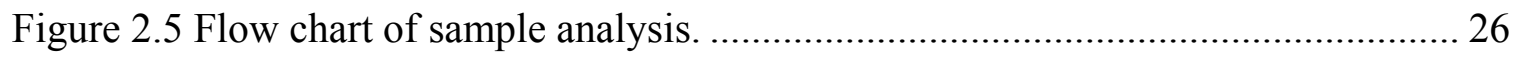

Figure 2.6 Percentile graph for Irgarol at Miami River, 2008 .................................. 39

Figure 2.7 Percentile graph for M1 at Miami River, 2008. ...................................... 39

Figure 2.8 Percentile graph for Irgarol at Coconut Grove, 2006 - 2008....................... 41

Figure 2.9 Percentile graph for M1 at Coconut Grove, 2006 - 2008............................ 42

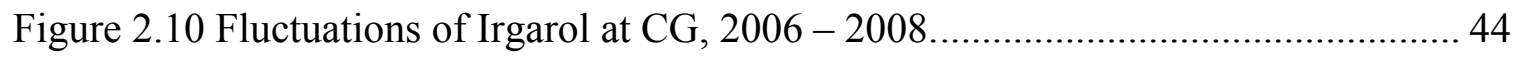

Figure 2.11 Percentile graph for Irgarol at KLH, 2004 - 2008 .................................. 46

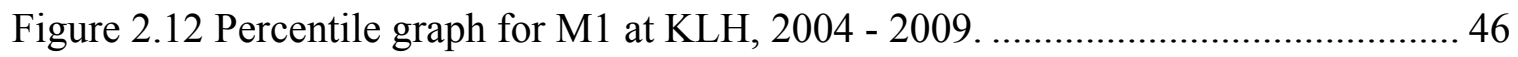

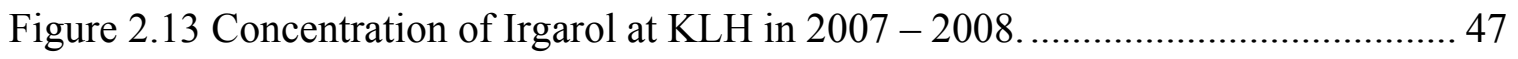

Figure 2.14 Irgarol percentile graphs for, 2004-2008........................................... 50 


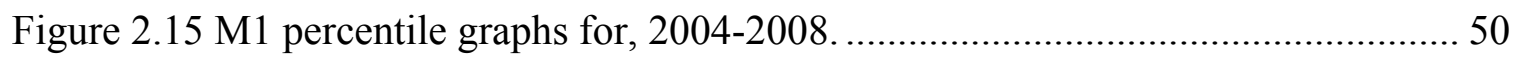

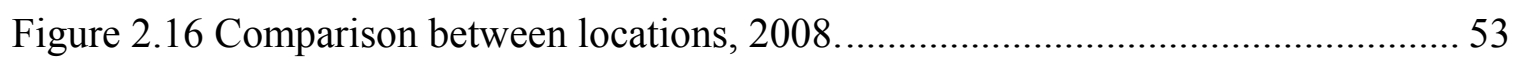

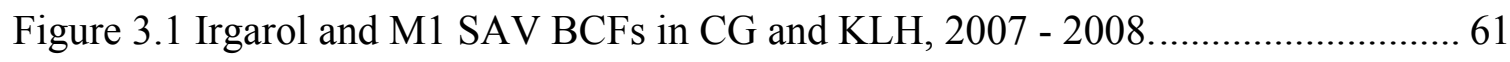

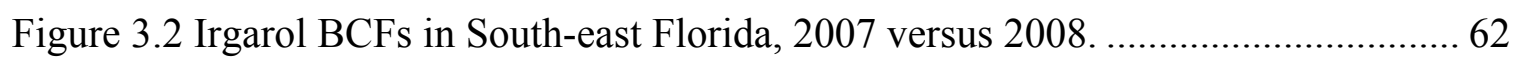

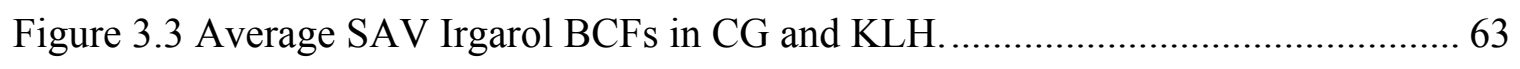

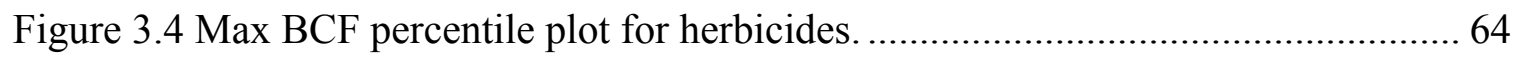

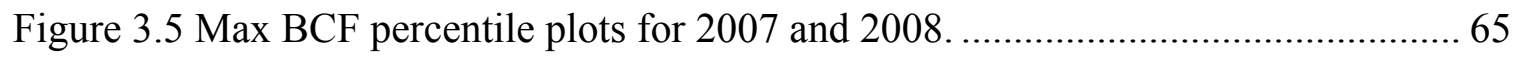

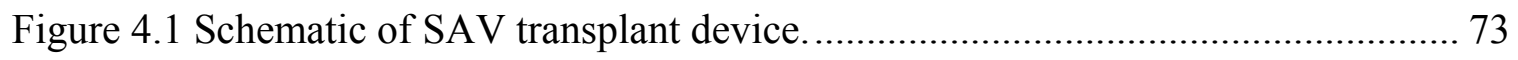

Figure 4.2 Distribution of Irgarol in Halodule and Thalassia. ................................... 76

Figure 4.3 Distribution of Irgarol throughout Halodule and Thalassia......................... 77

Figure 4.4 Uptake and depuration of Irgarol by Halodule and Thalassia. ...................... 80 



\title{
I. Introduction
}

\author{
1.1. Irgarol 1051: A Review
}

\subsubsection{Overview}

Irgarol 1051 (2-methythiol-4-tert-butylamino-6-cyclopropylamino-s-triazine)

(Figure 1.1) is the most popular and frequently detected organic antifouling agent currently in use worldwide and the first to be recognized as an environmental contaminant (Konstantinou et al. 2004). Its algicidal action occurs by highly specific but reversible binding to the $\mathrm{D} 1$ protein in the photosystem II complex, selectively blocking a pivotal step of the electron transport chain (Boger et al. 1998). As an algaecide it is combined with copper or other copper compounds to prevent fouling. Its intended for use in marine antifouling coatings including, but not limited to, yatches and other pleasure crafts, industrial vessels and mariculture devices (Ciba-Geigy 2004).

Irgarol is a white powder having a water solubility lower than Atrazine $(7 \mathrm{mg} / \mathrm{L}$ and $33 \mathrm{mg} / \mathrm{L}$ in salt and fresh water, respectively). It has been shown to be more effective than any other antifoulant at inhibiting growth of fresh or saltwater algae at levels as low as $10 \mathrm{ppb}$ (Ciba-Geigy 2004). It was first registered with the United States EPA in 1994 but was already in use throughout Europe. The ban on other highly toxic organoherbicides has resulted in a worldwide increase of Irgarol use causing concerns regarding its environmental impact. Therefore, numerous studies pertaining to its environmental occurrence, toxicity and fate have been performed over the last 19 years.

The relatively high octanol-water partitioning coefficient of Irgarol, $\log \mathrm{K}_{\mathrm{ow}}=$ 
3.95 (Bard et al. 1992), suggests a preference for the compound to partition into sediment in an aquatic environment. Environmental studies, however, have shown this to not be the case. Instead, Irgarol associates with sediments only when it remains associated with paint particles chipped from ship hulls. Irgarol will only then slowly leach from the paint particles and associate with the sediments (Thomas et al. 2002).

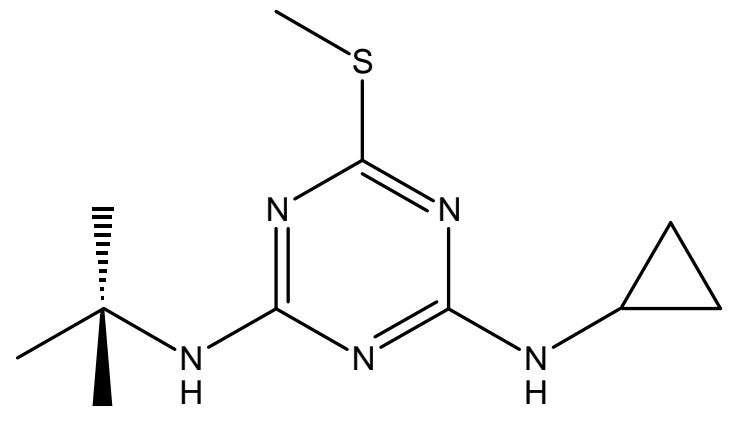

Figure 0.1 Structure of Irgarol.

\subsubsection{Occurrence}

Levels of Irgarol in surface waters are a function of input from mainly in-water stored vessels, dilution, flushing of contaminated marine environments, and degradation by photolysis, hydrolysis and humic degradation. The main source of Irgarol in the environment is through leaching from painted structures directly into the water column over time (Thomas et al. 2002).

This compound was first reported in Côte d'Azure, France marine costal surface waters at levels up to $1700 \mathrm{ng} / \mathrm{L}$ in the region (Readman et al. 1993). Subsequently, Irgarol has been investigated throughout the world's coastal environments. Available literature pertaining to this compound focuses on occurrence along coastal areas along Europe and Asia. In the last fifteen years a survey of the United States and Caribbean 
islands have been undertaken (Gardinali et al. 2002; Gardinali et al. 2004; Hall et al. 2004; Owens et al. 2002). Today Irgarol is considered a ubiquitous substance in coastal areas where boating activity occurs.

Worldwide, concentrations of Irgarol vary greatly and correlate with both seasonal boating practices and quantity of boats present in sampling locations. Surface waters collected during months associated with increased boating activity, such as summer, generally contain higher concentrations of Irgarol than months with little or no boating activity (Gough et al. 1994; Hall et al. 1999; Rogers et al. 1996; Scarlett et al. 1997; Tolosa et al. 1996). Surface water concentrations of Irgarol in the United Kingdom estuary, Hamble, show seasonal variability (Boxall et al. 2000; Gough et al. 1994; Thomas et al. 2001). Levels are higher in the summer compared to the winter months and are comparable to previously published concentrations in South-east Florida. Overall concentrations of Irgarol are higher Mediterranean ports and marinas, such as Côte d'Azur and the Monaco Riviera, France and South-east Spain (Readman et al. 1993; Tolosa et al. 1996), compared to South-east Florida. Within the United States surface water concentrations of Irgarol are higher on the East coast than on the West coast. For example, concentrations of Irgarol in Port Annapolis and Severn River, Maryland (Hall et al.; Hall et al. 2004) greatly exceed those of South-east Florida while more recently recorded levels in California marinas (Hall et al. 2008) are comparable to historical levels in CG and KLH. A summary outlining the presence of Irgarol throughout the world found in current literature is presented in APPENDIX A. 


\subsubsection{Environmental Fate}

The most important route of Irgarol environmental contamination is through leaching from submerged hulls of vessels over the lifetime of the paint (Thomas et al. 2002). Therefore, environmental concentration depends on the number of vessels and vessel treatment (Konstantinou et al. 2004). Removal of Irgarol from surface waters can occur via biotic degradation, photo-degradation, chemical hydrolysis, sedimentation, volatilization, bioaccumulation and water turnover (Readman 2006). This compound seems to persist in surface seawaters because of its long environmental half-life of 200 days (Ciba-Geigy 2004).

To date three degradation products of Irgarol have been identified in natural waters: 2-methythiol-4-tert-butylamino-6-amino-s-triazine (also known as GS26575 and M1) (Balcomb et al. 2002; Liu et al. ; Liu et al. 1999; Okamura 2002; Okamura et al. 1999), 3-[4-tert-butylamino-6-methylthiols-triazin-2-ylamino]-propionaldehyde (M2) (Lam et al. 2004; Ogawa et al. 2004) and N, N'-di-tert-butyl-6-methylthiols-s-triazine2,4-diamine (M3) (Lam et al. 2009) (Figures 1.2, 1.3 and 1.4, respectively). An s-triazine species likely containing an $\mathrm{N}$-allylic alcohol functionality (M4) has also been proposed but its chemical structure has yet to be determined (Lam et al. 2009). The metabolite M1 is the major degradation product in natural samples, indicating that degradation of Irgarol is slow. Additionally, all three degradation products are reportedly found at lower concentrations than Irgarol in the environment. A summary of the Irgarol degradation scheme is shown in Figure 1.5.

While photodegradation studies have shown Irgarol readily undergoes 
photodegradation in the environment, there is no consensus on the actual degradation kinetics. Ciba-Giegy states the half-life of Irgarol in seawater and freshwater is 100 and 200 days, respectively (Ciba-Geigy 2004). Published data from two separate studies also suggests degradation can be influenced by dissolved organic matter. Humic and fulvic material were shown to increase the degradation half-life to between 2 to 9 hours (Sakkas et al. 2002) or between 6.8 to 39 hours (Okamura et al. 2004) depending on the amount of the organic matter present.

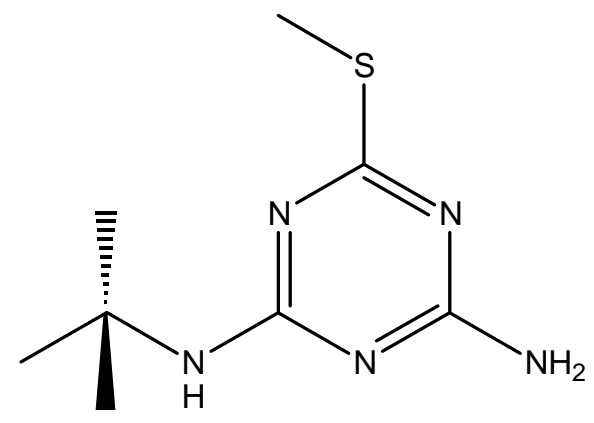

Figure 0.2 Structure of Irgarol metabolite M1.

M1 (Figure 1.2) is the major metabolite produced from photodegradation via $\mathrm{N}$ dealkylation and is considered the ultimate degradation product of Irgarol (Liu et al. 1999). Controversy exists concerning the environmental persistence of M1. One study proposed that M1 has a similar half-life to Irgarol (Hall et al. 1999) while a more recent study found that M1 has a greater environmental persistence (Okamura et al. 2000b). Photodegradation rates of M1 were slower (200 days) than the parent compound (100 days), suggesting that it will persist in the environment longer than Irgarol (Thomas et al. 2002). The metabolite M1 is also a more polar and hydrophilic compound compared to the parent compound Irgarol. Therefore, partitioning of M1 into sediment is expected to be lower than Irgarol (Lambert et al. 2006). 
The ability of Irgarol to undergo transformation by hydrolysis, both heavy metal catalyzed and non-catalyzed, have been investigated. Direct hydrolysis has shown Irgarol to be very stable. A six-week period of continuous hydrolysis resulted in Irgarol concentrations decreasing by only $20 \%$. Therefore Irgarol is essentially unaffected by direct hydrolysis (Okamura et al. 1999). Heavy metal catalysis using copper (II) chloride, silver nitrate, cadmium chloride, lead (II) chloride and zinc chloride showed nondetectable Irgarol hydrolysis in solution. Only mercuric chloride was shown to completely hydrolyze Irgarol independent of $\mathrm{pH}$ or other factors to an $\mathrm{M} 1$ final product (Liu et al. 1999). Additionally, Phanerochaete chrysosporium, a white rot fungus known to degrade a wide variety of aromatic compounds, has been shown to degrade Irgarol to M1 as well (Liu et al. 1997).

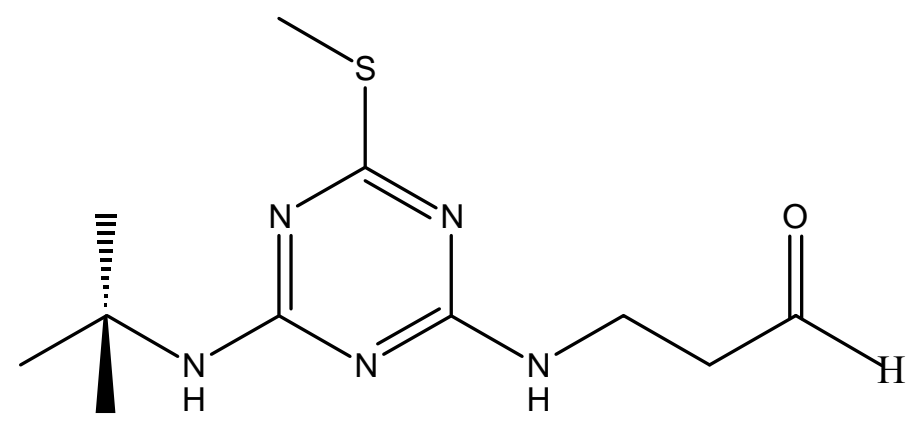

Figure 0.3 Structure of Irgarol metabolite M2.

In 2004 a minor degradation product, designated M2, was identified (Figure 1.3) (Lam et al. 2004). This product was not detected before because of its suspected degradation to M1 in GC-MS systems. The metabolite M2 is more polar and hydrophilic than Irgarol and so partitioning of M2 into sediment is expected to be lower (Lambert et al. 2006). It is thought M2 degrades to an M1 final product in the environment. 
A third degradation product, designated M3 (Figure 1.4), was detected during aqueous titanium dioxide-catalyzed photodegradation (Lam et al. 2005). It is thought to form as a minor side product of the industrial production of Irgarol (Konstantinou et al. 2004).

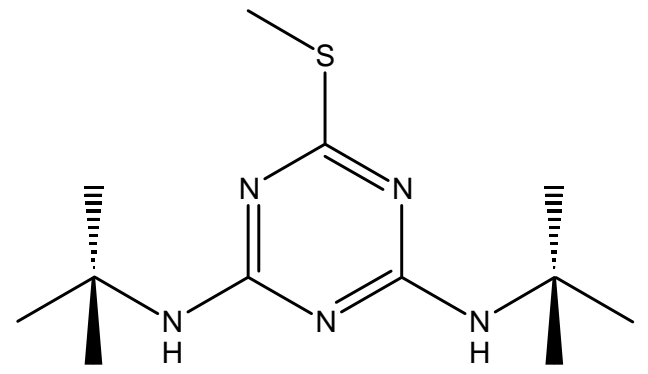

Figure 0.4 Structure of Irgarol metabolite M3.

Most recently a fourth degradation product, designated M4, was proposed. It is thought to form by oxidative ring-opening and to subsequently degrade into M1 either directly or indirectly via M2 formation (Lam et al. 2009) (Figure 1.5). 


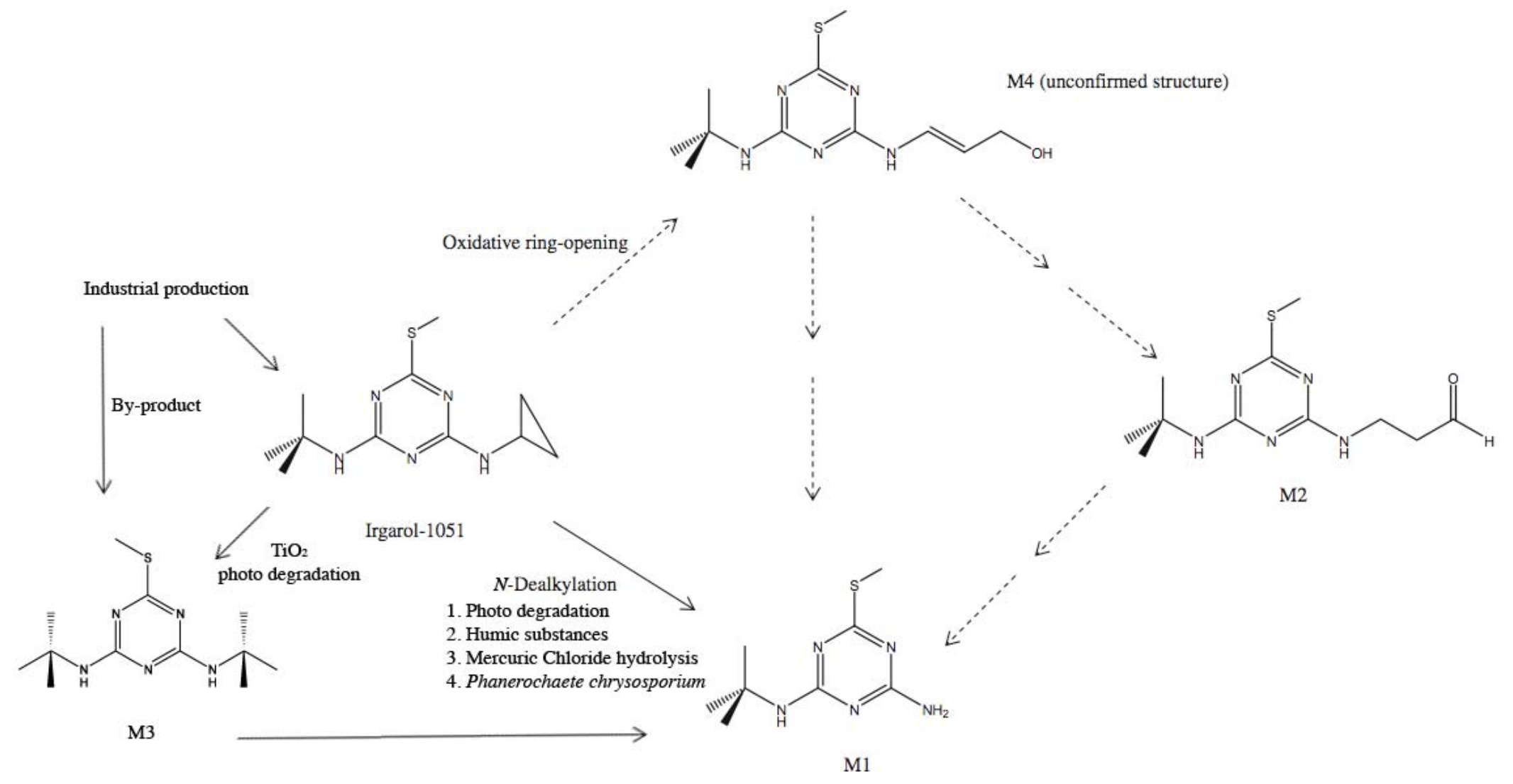

Figure 0.5 Summary of the Irgarol degradation pathway and metabolite formation.

Modified from (Lam et al. 2009). 


\subsubsection{Toxicity}

Irgarol is an inhibitor of the photosynthesis II process in marine algae causing reduced carbon dioxide uptake and eventual death. Data indicate Irgarol toxicity decreases with increasing complexity of marine organisms. For example, periphyton, zooplankton and phytoplankton $\mathrm{EC}_{50}$ are three to four magnitudes lower than for seaweed, seagrass, algae and microphytes, the latter ranging approximately $10^{6}-10^{7}$ ng/L. The crustacean Daphnia magna have the highest $\mathrm{EC}_{50}$, approximately $7 \times 10^{9} \mathrm{ng} / \mathrm{L}$. Toxicity studies show the coral Madracis mirabilis was the most sensitive organism to the presence of Irgarol. Levels as low as $63 \mathrm{ng} / \mathrm{L}$ affect the ability of zooxanthelle residing within the coral to uptake carbon and $100 \mathrm{ng} / \mathrm{L}$ reversibly inhibit photosynthesis on whole coral (Owens et al. 2002). Periphyton communities suffer adverse chronic effects between $90 \mathrm{ng} / \mathrm{L}$ to $310 \mathrm{ng} / \mathrm{L}$ of Irgarol (Mohr et al. 2009). Toxicological results for M1 show the metabolite is less toxic than Irgarol. Toxicity data for Irgarol and M1 available in the literature are listed in APPENDIX B.

Toxicity testing indicates plants are more sensitive to Irgarol than animals. Therefore, in addition to the concentration of Irgarol shown to affect coral, the conservative benchmark used to characterize risk is the plant $10^{\text {th }}$ percentile for both Irgarol (193 ng/L) and M1 (5622 ng/L) (Hall et al. 2009). Tenth percentiles for plant toxicity are compared to $90^{\text {th }}$ percentiles of water levels for Irgarol. The area is labeled at risk for toxic exposure when the $90^{\text {th }}$ percentile environmental exposure exceeds the $10^{\text {th }}$ percentile plant toxicity. 


\subsection{South Florida Submerged Aquatic Vegetation}

\subsubsection{An overview}

Seagrasses are marine angiosperms (flowering macrophytes) that include 50 species in 12 genera. They are not restricted to tropical latitudes though there is a tendency for more species to be present in the tropical zones (Hogarth 2007). The most abundant seagrasses along the Florida coast are Thalassia testudinum (family Hydrocharitaceae), Halodule wrightii and Syringodium filiforme (family Cymodoceaceae) (Carlson et al. 2007) (Figure 1.6). They form dense single or mixedspecies stands whose growth is limited by depth and overall water clarity since they require light for survival. The extent of seagrass coverage in South Florida, as measured by aerial photography, is estimated to be approximately 2.7 million acres (FF\&WCC 2003).

Thalassia is the dominant primary producer in tropical coastal seagrass communities. Meadows dominated by this species are amongst the most highly productive marine systems on Earth. Individual meadow species diversity can vary considerably from site to site (van Tussenbroek et al. 2006). Macrophytes (seagrasses such as Halodule and Syringodium and various rooted and drift macroalgae), benthic and epiphytic diatoms, and phytoplankton also contribute significantly to the total community production (Duarte 1995; Erftemeijer et al. 1995). Rhizophytic macroalgae associated with Thalassia in the Western Atlantic include various species of Halimeda, Udotea, Penicillus and Caulerpa (Figure 1.7). Common drift algae associated with Thalassia include Acetabularia and Anadyomene. Drifting algae can form extensive mats on top of 
seagrasses. Both drifting algal mats and epiphytes inhibit growth of seagrasses by shading and smothering the host plant and by competing for nutrients and gases (Duarte 1995).

Seagrasses uptake nutrients from their environment with equal contribution from both leaves and roots (van Tussenbroek et al. 2006). They lack stomata, therefore exchange nutrients through a thin cuticle covering their leaves.

Uptake rate of nutrients from the water by roots is controlled largely by sediment parameters and diffusion rates, whereas uptake of nutrients from the water column depends on the uptake capacity of the leaves (Stapel et al. 1996). Plants are able to exchange inorganic and organic substances with the environment while controlling their internal composition. In most cases toxic substances behave as nutrients, therefore a plant cannot discriminate between beneficial and detrimental compounds. Two basic criteria are required of Irgarol to be selected from the environment: (1) dissolution in an aqueous matrix and (2) the diffusive transport across lipid membranes as measured by the 1octanol-water coefficient. The water solubility of Irgarol (7 mg/L) and high $\mathrm{K}_{\mathrm{Ow}}(3.95)$ meets the criteria for contaminant uptake by SAVs.

Photosystem II (PS II) inhibitor herbicides can be classified as plastoquinone analogs since they replace plastoquione $\mathrm{Q}_{\mathrm{B}}$, a molecule involved in the electron transport chain from the stromal matrix of chloroplasts to the lumen of thylakoid disks, in its binding niche on D1. Irgarol is one such molecule causing a halt in electron transport. Excitation energy accumulates at $\mathrm{P}_{680}$ in a triplet state. Eventually this energy is transferred to molecular oxygen, forming singlet oxygen. Under normal steady state 
conditions the D1 proteins turnover frequently. In the presence of Irgarol singlet oxygen is generated in the extreme vicinity of the PSII reaction center and causes permanent inhibition of the D1 repair cycle through photo and eventual tissue damage (Hock et al. 2005).
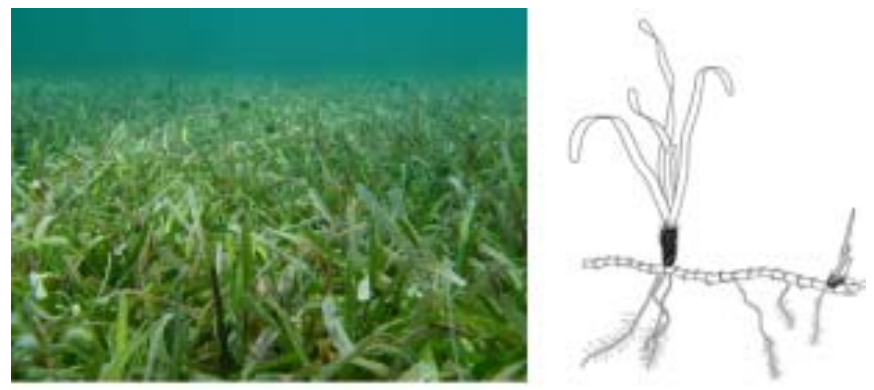

Thalssia testudinum
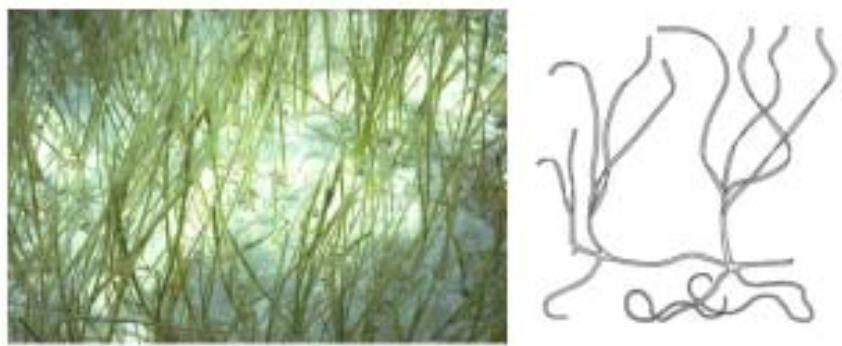

Halodule wrightii
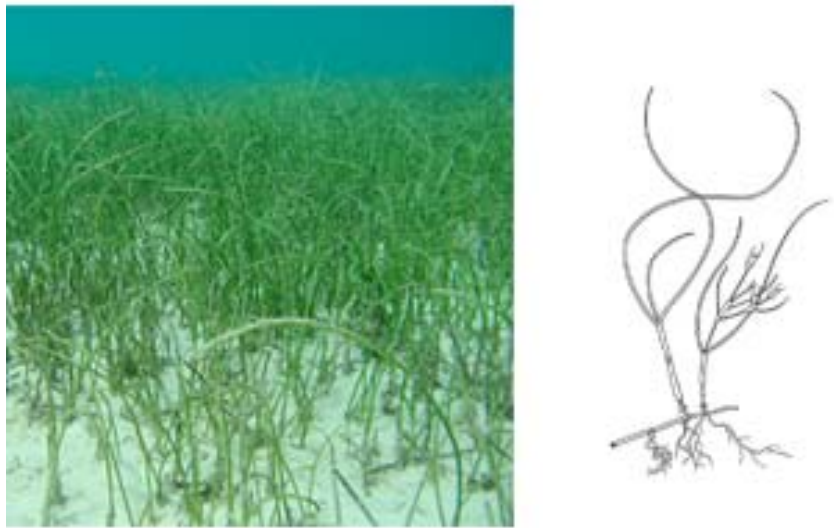

Syringodium filiforme

Figure 0.6 Three major marine angiosperms found in south-Florida coastal waters. 


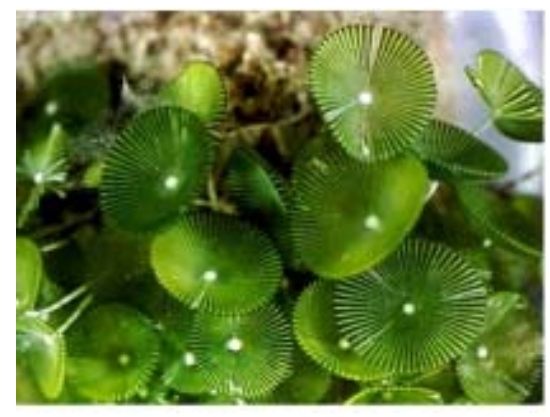

Acetabularia

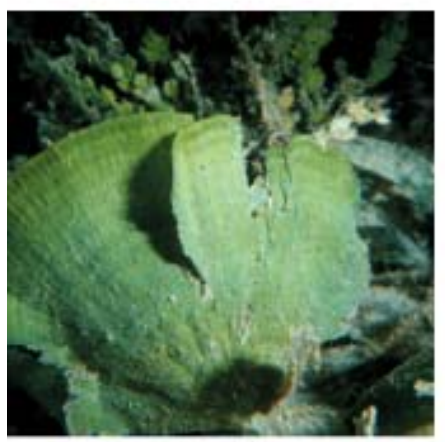

Udotea

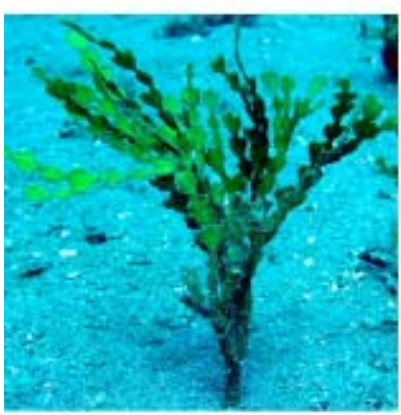

Halimeda

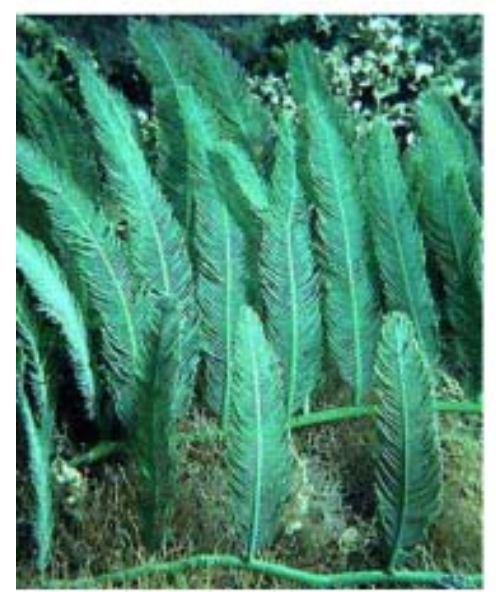

Caulerpa

Figure 0.7 Four macroalgae present in south-Florida coastal waters. 


\subsubsection{Bioaccumulation in of Irgarol}

The BCF contains information about the kinetics of uptake and depuration processes such as metabolism and excretion (Ranke et al. 2000). This correlation exists because the same molecular forces controlling the distribution of compounds between waterimmiscible organic solvents and water also determine environmental partitioning from water into natural organic phases. A scheme for evaluating the bioaccumulation tendency of a compound is shown in Table 1.1. Irgarol's $K_{O W}$ (3.95) indicates it should be bioaccumulated by SAVs.

Very few studies concerning Irgarol uptake and accumulation by submerged vegetation reports exist. Irgarol bioaccumulation in SAVs has been investigated in various species submerged vegetation such as the green algae Tetraselmis suecica (in a laboratory setting) (Dyer et al. 2006) and Chlorodesmis fastigiata, and the seagrasses Halodule and Zostera marina in natural and environmental settings (Scarlett et al. 1999a; Scarlett et al. 1999b). The controlled Irgarol uptake study fluctuating levels of Irgarol uptake Zostera marina and Halodule sampled off the coast of Queensland, Australia and a wide variability in Irgarol accumulation ranging from non-detected (N.D.) to $118 \mathrm{ng} / \mathrm{g}$ (Scarlett et al. 1999b). Scarlett et al. proposed bioconcentration factors (BCFs) up to 25,000 in Zostera marina (Scarlett et al. 1999a) while reported BCFs up to 30,000 for fresh water macroalgae (Tóth et. al.1996) indicate that marine macroalgae can also function as indicators of Irgarol contamination.

The presence of D1 proteins in SAV leaves probably accounts for BCFs exceeding the predicted range of bioaccumulation (100-1000) (Ranke et al. 2000) (Table 1.1) and is probably independent of the $\mathrm{K}_{\mathrm{OW}}$ effect. A summary of all bioaccumulation data is 
available in Table 1.2.

Table 0.1 Scheme for evaluating the bioaccumulation tendency of a compound.

Values acquired from (Ranke et al. 2000).

\begin{tabular}{l|cccc}
\hline \multicolumn{1}{c|}{ Score } & $\mathbf{1}$ & $\mathbf{2}$ & $\mathbf{3}$ & $\mathbf{4}$ \\
\hline $\mathrm{BCF}$ & $<30$ & $30-100$ & $100-1000$ & $>1000$ \\
$\log \mathrm{K}_{\mathrm{OW}}$ & $<2.6$ & $2.8-3.5$ & $3.5-4.8$ & $>4.8$ \\
\hline
\end{tabular}


Table 0.2 Organismal bioaccumulation review.

\begin{tabular}{|c|c|c|c|}
\hline Organism & Max BCF (L/kg DW) & $\begin{array}{c}\text { Max Concentration } \\
\left(\mathrm{ng} / \mathrm{g} \mathrm{FW}^{\mathrm{a}} \mathrm{DW}^{\mathrm{b}}\right)\end{array}$ & Reference \\
\hline Myriophyllum verticillatum & 10560 & & (Mohr et al. 2009) \\
\hline Potamogeton nodosus & 1860 & & (Mohr et al. 2009) \\
\hline filamentous algae & 9250 & & (Nystrom et al. 2002) \\
\hline Elodea canadensis & 4497 & & (Nystrom et al. 2002) \\
\hline Potamogeton pectinatus & 2852 & & (Nystrom et al. 2002) \\
\hline Tetraselmis suecica & $84,822 \pm 32,394$ & & (Dyer et al. 2006) \\
\hline \multirow[t]{2}{*}{ Zostera marina } & 25,000 & & (Scarlett et al. 1999a) \\
\hline & & $790^{b}$ & (Scarlett et al. 1999b) \\
\hline Halodule & & $48^{\mathrm{a}}$ & (Scarlett et al. 1999b) \\
\hline Chlorodesmis fastigiata & & 0 & (Scarlett et al. 1999b) \\
\hline Freshwater macrophytes & 30,000 & & (Toth et al. 1996) \\
\hline Perna viridis (green mussels) & & $<0.76^{\mathrm{a}}$ & (Harino et al. 2006) \\
\hline
\end{tabular}




\subsection{Scope and Objectives of the Study}

Florida is a model area for Irgarol research since concentrations in surface water has been well documented (Gardinali et al. 2002; Gardinali et al. 2004). The presence of submerged vegetation enables identification of a sentinel organism for monitoring contamination in Biscayne Bay. The presence of Irgarol in this area may have chronic effects therefore necessitating further investigation of near-shore environments and potential effects on SAVs. Based on bioaccumulation studies in SAVs it is hypothesized they uptake and depurate Irgarol, and M1 to a lesser extent, with rapid kinetics. Additionally, SAVs are expected to bioaccumulate Irgarol in a species- and sampledependent manner due to variability in photosynthetic material along the leaves and between species. The primary goals of this research are as follows:

- Conduct an environmental assessment of Irgarol, M1 and M3 along the Southeastern Florida coastline in marine waters and sediments.

- Develop a simplified automated method to extract s-triazine herbicides from sediments and tissues using the Zymark Rapid Trace system.

- Determine the concentration of Irgarol and its major metabolites in submerged aquatic vegetation at two model areas, Key Largo Harbor and Coconut Grove.

- Determine the uptake and depuration rates of submerged aquatic vegetation by performing an in situ transplant study.

- Identify the submerged aquatic vegetation to serve as an ideal sentinel organism of Irgarol contamination in sensitive marine communities. 


\section{Occurrence of Irgarol, M1 and M3 in South Florida.}

\subsection{Study Areas in South Florida}

Marinas are designed to harbor recreational boats from strong waves and currents. For this reason they have a relatively low water exchange rate due to their semi-enclosed nature (Hall et al. 2004; Konstantinou et al. 2004; Okamura et al. 2000a). The low water turnover and high density of boating activity results in Irgarol concentrations significantly higher in marinas compared to open ports and other coastal environments.

South Florida weather allows for high boating activity year round thus reducing disparities in seasonal concentrations of Irgarol and its metabolites. Concentrations have been well established in Biscayne Bay and Key Largo Harbor areas (Gardinali et al. 2002; Gardinali et al. 2004; Zamora-Ley et al. 2006) (APPENDIX A). These locations are also densely populated with recreational crafts, mostly stored in water, resulting in exposure of the surrounding marine life to relatively consistent Irgarol concentrations year-round. The shallow areas around these marinas $(1.5-3.0 \mathrm{~m})$ and the clear waters allow for a diverse and dense submerged vegetation population to grow in close proximity with navigational channels. Consideration of several factors such as benthic communities and water circulations contributed to selection of Coconut Grove (CG), Miami River (MR) and Key Largo Harbor (KLH) (Figure 2.1) as locations of interest for this experiment.

Two locations within Biscayne Bay were chosen for sampling: Miami River and Coconut Grove (Table 2.1, Figure 2.2 and 2.3). Miami River is a six-mile long river home to large shipping operations and large commercial vessels as well as private 
boating activities. This river serves as an ideal location for assessing contributions from industrial and commercial industries to Irgarol contamination.

Coconut Grove is Florida's largest marine facility with 582 wet slips and a 225 offshore vessel mooring facility making this area the largest personal boating craft concentration in Biscayne Bay (Figure 2.2). Recreational vessels range from small watercrafts to large pleasure crafts up to 12 meters in length. The channels leading out from CG are home to many seagrass beds. At low tide water flows out from the marina over the seagrass beds, increasing their risk of Irgarol exposure. Water circulation is very high because of the open nature of this marina. Previous research has shown maximum Irgarol concentrations in CG at about $69 \mathrm{ng} / \mathrm{L}$ since 1999 (Gardinali et al. 2002; Gardinali et al. 2004 ; Zamora-Ley et al. 2006).

Chicken Key is an island located in Biscayne Bay located approximately $12.8 \mathrm{~km}$ south of CG. It is a pristine site with high water turn over and a thick dense Thalassia bed approximately 2.0 meters below the water surface. Human activity is infrequent because of shallow waters and protection of the seven-acre mangrove island and restored bird rookery. Most of the human activity is associated with sea kayaking and island exploration.

Key Largo Harbor has been reported to have the second highest Irgarol concentration in the United States with levels around $200 \mathrm{ng} / \mathrm{L}$ (Gardinali et al. 2004; Owens et al. 2002). Key Largo Harbor differs from CG in that it is a mostly residential area comprised of approximately 200 houses with personal docking along the harbor and a few marine service facilities, hotels and restaurants (Figure 2.4). Additionally, its 
geometric layout is unique, consisting of one main channel running north and south with the exit at the extreme south and multiple minor channels containing the residential boats branching west from the main channel (Figure 2.1). At the upmost north end, the main channel changes direction to run west where the marine facilities, restaurants and hotels are located. Water circulation within KLH is very low, decreasing at the north- and westmost extremities of the minor and main channel. While the harbor itself is too deep to contain seagrass beds, located just outside of the harbor is a large, healthy and accessible seagrass bed. 

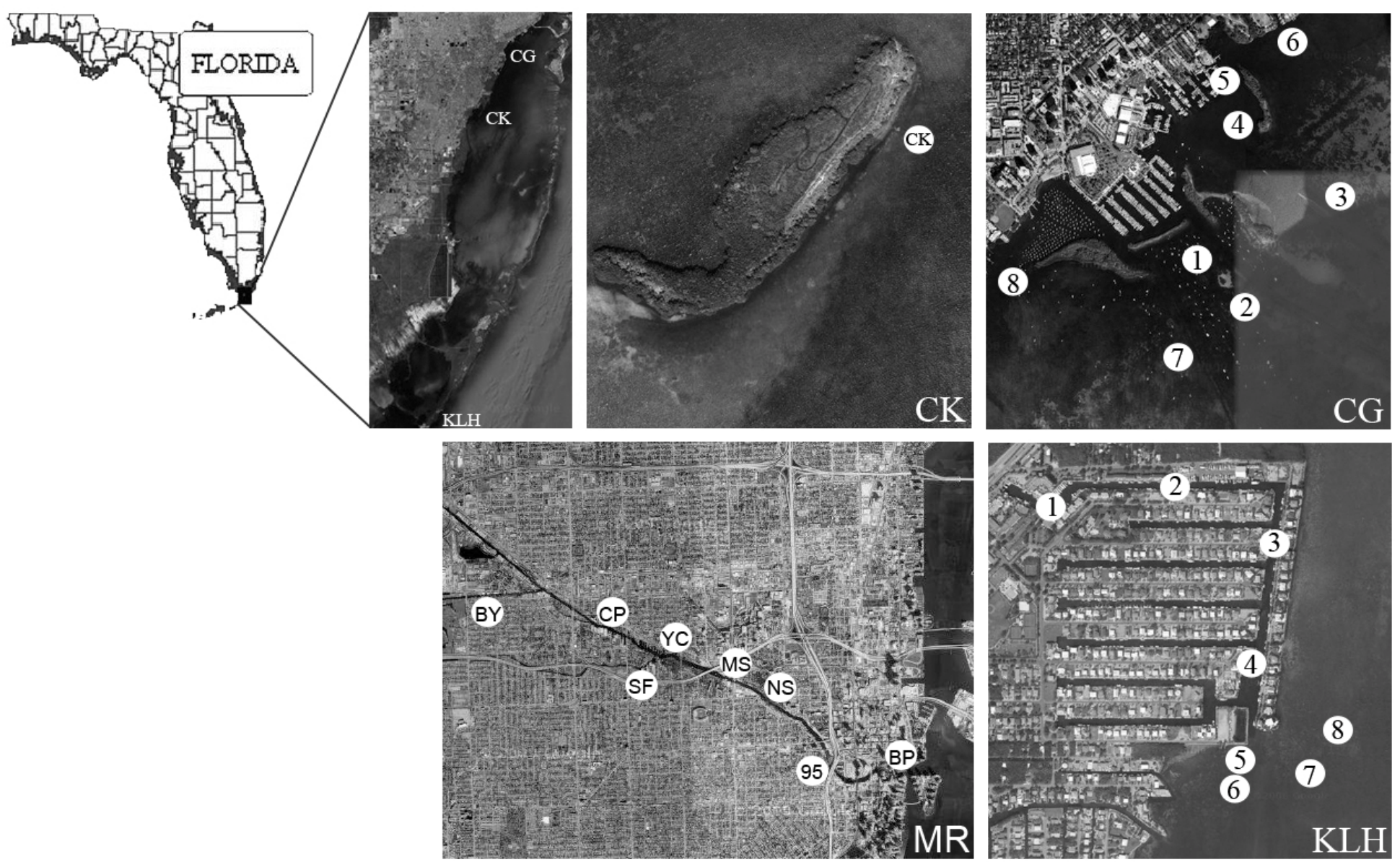

Figure 0.1 Study areas in Southeastern Florida.

Images acquired from Google Maps. 


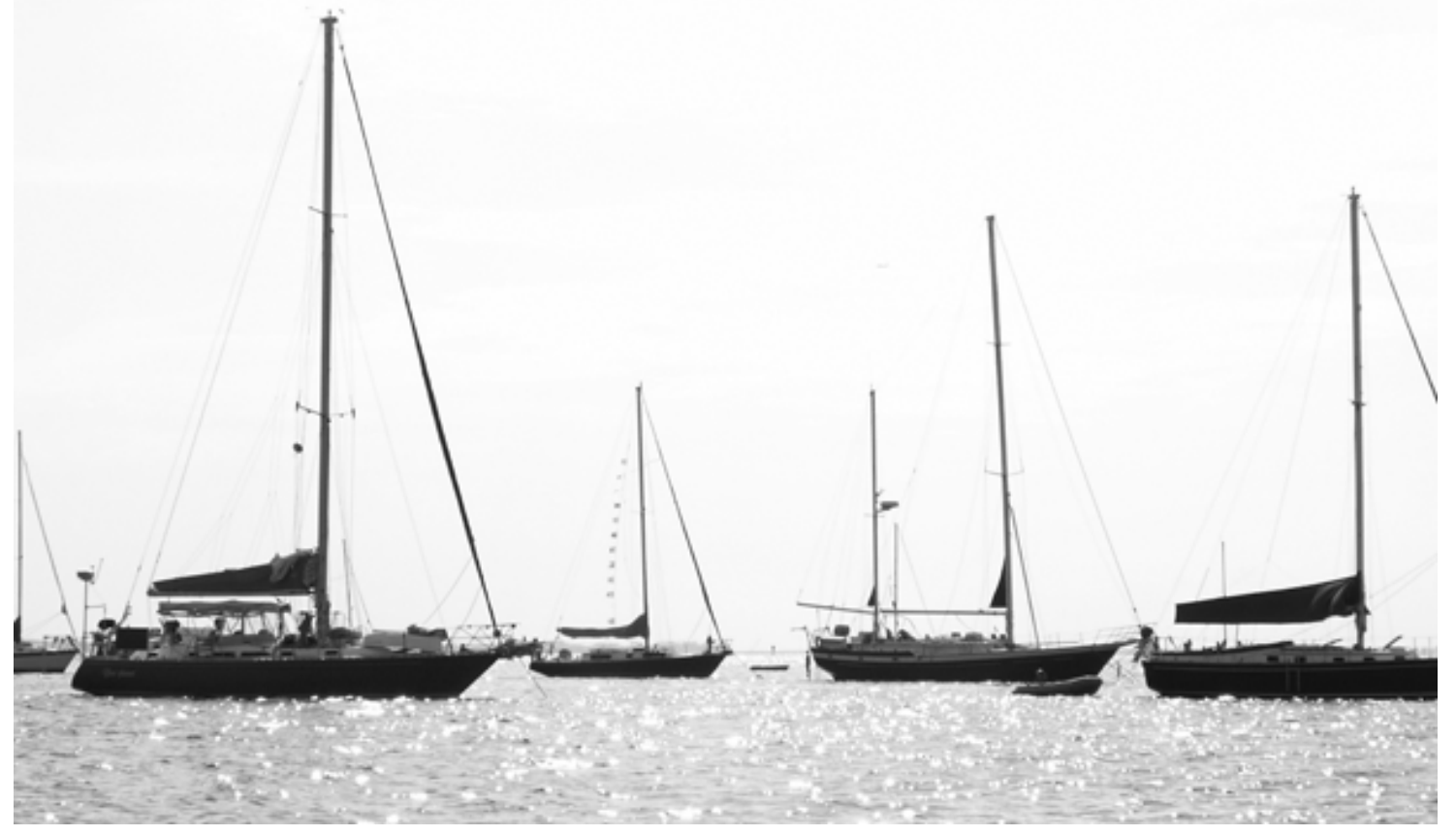

Figure 0.2 Coconut Grove.

The above image shows in water storage of sailboats at the South-eastern corner of the marina, an unenclosed area with the highest water turnover. Photograph taken by Melissa V. Fernandez. 

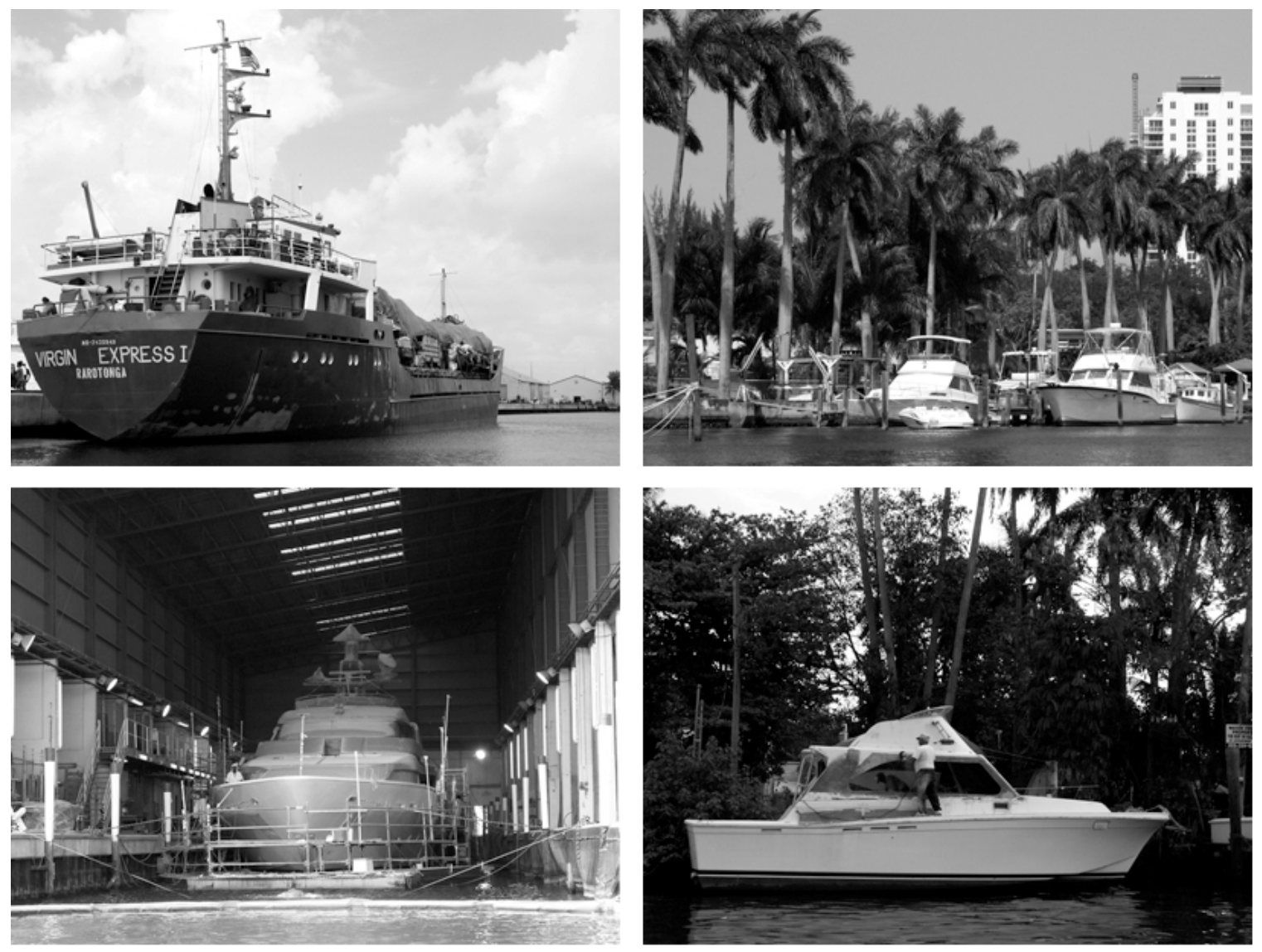

Figure 0.3 Miami River watercraft storage trends.

The above image shows the various types of water vessels, their storage and the types of human activity that occur along the river. In the top left is a large commercial vessel. Below it is a large pleasure craft undergoing repairs and maintenance in a warehouse. In the top right are shown private boats docked along private residential docks. Underneath is a vessel in the process of being sanded down with the paint dust landing on the surface water. Photographs taken by Melissa V. Fernandez. 

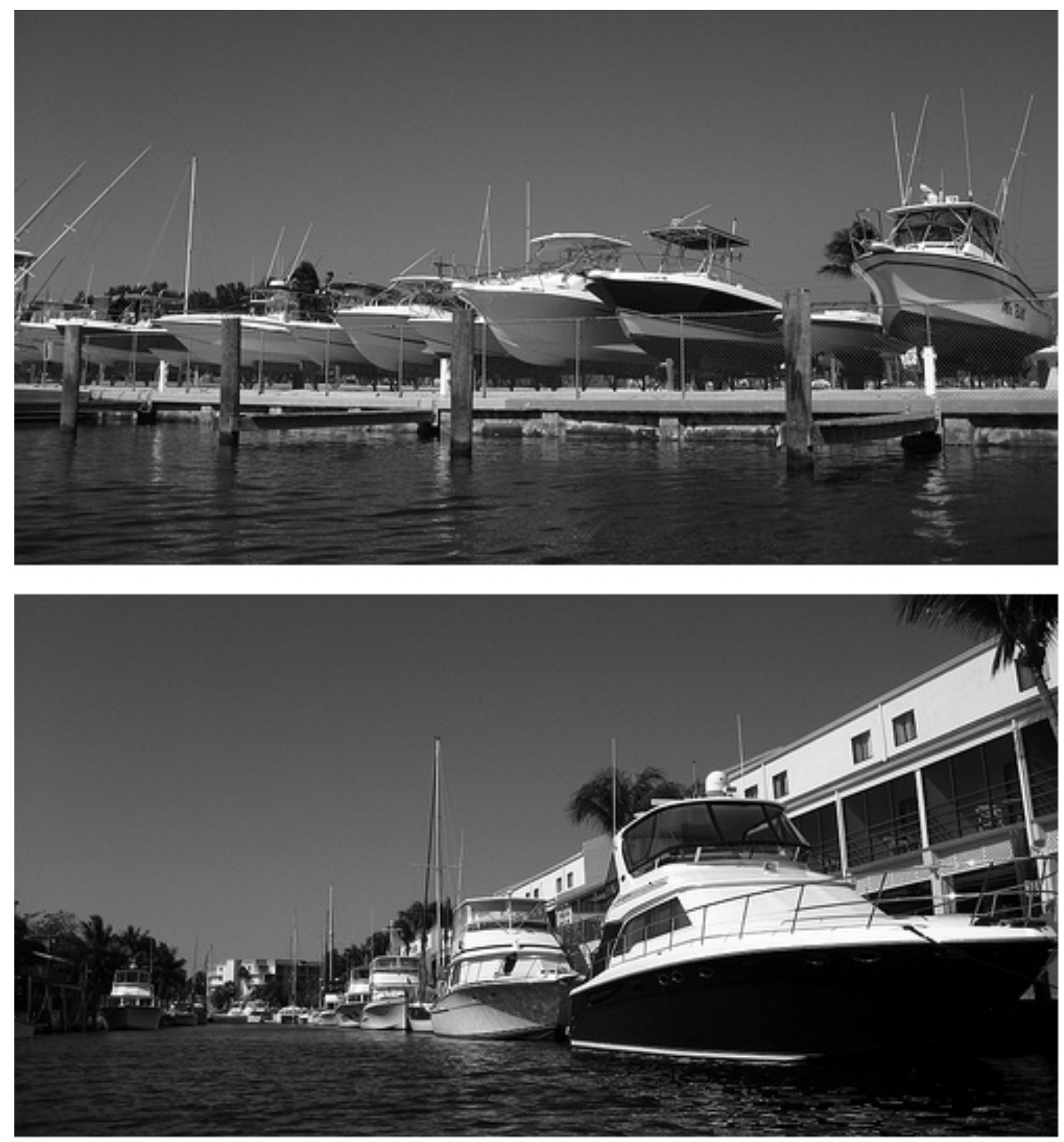

Figure 0.4 Key Largo Harbor watercraft storage trends.

The above image shows above water storage of crafts in the marine facilities at the Northwestern end of the harbor. The bottom image shows personal craft storage in water off the private residential docks along the western branches off the main channel. Photographs taken by Melissa V. Fernandez. 
Table 0.1 Study area coordinates.

\begin{tabular}{|c|c|c|c|}
\hline & LOCATION & LATITUDE & LONGITUDE \\
\hline \multirow{8}{*}{ 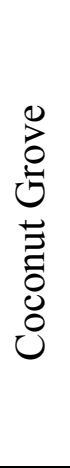 } & CG01 & 25.7249 & 80.2307 \\
\hline & CG02 & 25.7222 & 80.2265 \\
\hline & CG03 & 25.7261 & 80.2232 \\
\hline & CG04 & 25.7297 & 80.2280 \\
\hline & CG05 & 25.7320 & 80.2286 \\
\hline & CG06 & 25.7335 & 80.2260 \\
\hline & CG07 & 25.7191 & 80.2310 \\
\hline & CG08 & 25.7232 & 80.2391 \\
\hline \multirow{8}{*}{ 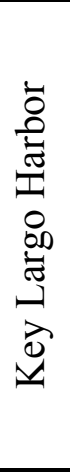 } & KLH01 & 25.0957 & 80.4367 \\
\hline & KLH02 & 25.0961 & 80.4326 \\
\hline & KLH03 & 25.0941 & 80.4305 \\
\hline & KLH04 & 25.0910 & 80.4310 \\
\hline & KLH05 & 25.0888 & 80.4315 \\
\hline & KLH06 & 25.0883 & 80.4317 \\
\hline & KLH07 & 25.0885 & 80.4298 \\
\hline & KLH08 & 25.0894 & 80.4290 \\
\hline \multirow{9}{*}{ 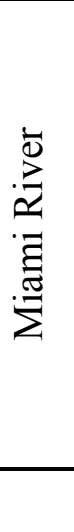 } & MR95 & 25.7711 & 80.1998 \\
\hline & MRBP & 25.7698 & 80.1896 \\
\hline & MRBY & 25.7950 & 80.2528 \\
\hline & MRCP & 25.7902 & 80.2346 \\
\hline & MRMS & 25.7832 & 80.2165 \\
\hline & MRNS & 25.7799 & 80.2097 \\
\hline & MRSF & 25.7844 & 80.2292 \\
\hline & MRYC & 25.7863 & 80.2238 \\
\hline & Chicken Key & 25.6222 & 80.2837 \\
\hline
\end{tabular}




\subsection{Experimental}

\subsubsection{Overview}

All biological samples underwent extraction procedures before concentration and CG-MS analysis (Figure 2.5). The extraction procedures are similar for sediment and SAV samples and involve ASE followed by SPE. Water extraction was a 2 L liquidliquid extraction with methanol. All components of sample analysis are described throughout the remainder of this chapter section.

\section{Sample collection $\longrightarrow$ Sample storage $\longrightarrow$ Extraction $\longrightarrow$ Analysis}

\section{Water}

Liquid-Liquid Extraction $\longrightarrow$ Concentrate $\longrightarrow$ GC-MS

\section{Sediment / SAV}

$\mathrm{ASE} \longrightarrow \mathrm{SPE} \longrightarrow$ Concentrate $\longrightarrow$ GC-MS

Figure 0.5 Flow chart of sample analysis.

\subsubsection{Chemicals}

Irgarol 1051 and M1 were obtained from Ciba Specialty Chemicals (Tarrytown, New York, USA). Atrazine-d5 surrogate standard was purchased as a certified standard solution from Dr. Ehrenstorfer GmbH (Ausburg, Germany). Atrazine and M3 were purchased from Sigma Aldrich. All glassware used in the experiments and sample processing was rinsed and combusted at $450{ }^{\circ} \mathrm{C}$ for 4 hours to removed all organic 
residues. All solvents were pesticide grade and purchased from Fisher Scientific (Fair Lawn, New Jersey, USA).

\subsubsection{Sample Collection}

\subsubsection{Surface Water Samples}

Samples for environmental monitoring were collected from eight locations within MR, CG and KLH each and one from CK (Table 2.1, Figure 2.1). Surface water samples were collected in 4-liter amber glass bottles from a boat free of antifouling paint. The environmental descriptors dissolved oxygen, salinity and temperature were recorded with a YSI85 handheld meter and $\mathrm{pH}$ was recorded with a YSI60 at each sampling location. Upon return to the laboratory aqueous samples were immediately stored in a dark refrigerator kept between $1{ }^{\circ} \mathrm{C}$ and $4{ }^{\circ} \mathrm{C}$.

\subsubsection{Sediment Samples}

Samples for environmental monitoring were collected from eight locations within CG and KLH each. Sediment samples were collected from a boat free of antifouling paint. Sediments were collected directly by hand using $250 \mathrm{~mL}$ pre-cleaned certified ICHEM glass jars. The majority of water was decanted before sealing the jar. Upon return to the laboratory sediment samples were immediately stored in a dark refrigerator kept below $-10{ }^{\circ} \mathrm{C}$. 


\subsubsection{Sample Extraction}

\subsubsection{Surface Water Samples}

The extraction procedure for water samples has been described elsewhere (Gardinali et al. 2004; Zamora-Ley et al. 2006). Two liters of water were filtered to remove large particulate matter and poured into a $2 \mathrm{~L}$ separatory funnel. Sodium chloride (20 g) was added to the water to increase the ionic strength and assist in extraction of herbicides by methylene chloride. A $100 \mu \mathrm{L}$ aliquot of internal standard, Atrazine-d5 (1.00 ppm), was then spiked into each sample to account for losses. Extractions were performed with $50 \mathrm{~mL}$ of pesticide grade methylene chloride in triplicates using vigorous shaking for at least two minutes. The combined organic layers were dried through anhydrous sodium sulfate and collected in flat-bottom flasks. The sample extracts were evaporated to $10 \mathrm{~mL}$ in a $60^{\circ} \mathrm{C}$ water bath. The remaining sample was transferred to a Kuderma-Danish concentration tube and the volume gradually reduced and exchanged to $1 \mathrm{~mL}$ of hexane in a $60^{\circ} \mathrm{C}$ water bath. A recovery standard (tetrachloro-m-xylene, TCMX, $100 \mu \mathrm{L}, 1 \mathrm{ppm}$ ) was added to the concentration tubes before the sample was transferred to amber $\mathrm{GC}$ vials and stored at $4^{\circ} \mathrm{C}$ or below until analysis.

\subsubsection{Sediment Samples}

Wet sediments $(20-40 \mathrm{~g})$, equivalent to a $10 \mathrm{~g}$ dry weight sample, were measured and dispersed in pre-cleaned diatomaceous earth (DE) before packing into $33 \mathrm{~mL}$ Accelerated Solvent Extraction (ASE) cells and extracted on a Dionex ASE 200 using 50 $\mathrm{mL}$ 90:10 methanol/water at $100^{\circ} \mathrm{C}$ and 1500 PSI. Methanol was then removed by rotary evaporation and the remaining sample extract was then quantitatively transferred to a 
centrifuge tube. Samples were centrifuged for 30 minutes at $15^{\circ} \mathrm{C}, 3500 \mathrm{RPM}$ to remove solids and large particulates. The supernatant was transferred to $12 \mathrm{~mL}$ test tubes and purified with the Oasis HLB cartridge $(60 \mathrm{mg}, 3 \mathrm{cc})$ and the Zymark Rapid Trace Workstation using the method described in the 2.2.4.3.2 Automated Solid Phase Extraction section below. The sample extracts were dried under nitrogen gas and reconstituted in $1 \mathrm{~mL}$ hexane. A recovery standard, TCMX $(100 \mu \mathrm{L}, 1 \mathrm{ppm})$, was added to the samples and the extracts were transferred to a $2 \mathrm{~mL}$ amber vial and stored at $4{ }^{\circ} \mathrm{C}$ until analysis.

\subsubsection{Solid Phase Extraction of Sediment Samples}

Manual and automated SPE were performed on fortified blanks, sediments and SAV samples. Recoveries of fortified samples were then compared to determine whether the automated method was equivalent or improved to the manual SPE method.

\subsection{Manual Solid Phase Extraction}

Oasis HLB Plus cartridges (225 mg/6 $\mu \mathrm{m}$, vacuum type, catalog \#: 186000132) were fitted with a Whatman GF/B glass fiber filter to trap any remaining particulate matter left in the samples. The cartridge was then conditioned with $10 \mathrm{~mL}$ of methanol at a rate below $2 \mathrm{~mL} / \mathrm{min}$ followed by equilibration with $5 \mathrm{~mL}$ of distilled deionized water (DDI). These liquids were collected as waste and discarded. The aqueous sample obtained from ASE extraction was loaded onto the cartridge at a rate of $1 \mathrm{~mL} / \mathrm{min}$. The cartridge was then air dried to remove traces of water. Analytes were eluted using $10 \mathrm{~mL}$ of methylene chloride at a rate of $1 \mathrm{~mL} / \mathrm{min}$ into a $15 \mathrm{~mL}$ glass test tube. Samples were 
then quantitatively transferred by passing through sodium sulfate to dry the extract into a $25 \mathrm{~mL}$ Kimax concentrator tube and evaporated to a final volume of $1 \mathrm{~mL}$ in hexane by solvent exchange. A $100 \mu \mathrm{L}$ aliquot of 1ppm TCMX internal standard solution was added, and the samples were transferred into an amber vial for storage until GC-MS analysis.

\subsection{Automated Solid Phase Extraction}

Oasis HLB cartridges (60 mg/3 cc, syringe type, catalog \#: WAT094226) were conditioned in with $3 \mathrm{~mL}$ methanol at a rate of $2 \mathrm{~mL} / \mathrm{min}$ followed by $3 \mathrm{~mL}$ of DDI water at $2 \mathrm{~mL} / \mathrm{min}$. Samples extracts were diluted to $7 \mathrm{~mL}$ with DDI water and loaded onto the cartridge at a rate of $1.1 \mathrm{~mL} / \mathrm{min}$. The cartridge was then rinsed with $2 \mathrm{~mL}$ DDI water at a rate of $1 \mathrm{~mL} / \mathrm{min}$ to remove contaminants and dried for forty minutes using pointed nitrogen gas. The system was then purged with $5 \mathrm{~mL}$ each at $30 \mathrm{~mL} / \mathrm{min}$ of the following solvents at a rate of $30 \mathrm{~mL} / \mathrm{min}$ to prevent carryover of samples and contaminants: methanol, acetone and methylene chloride. Analytes were eluted from the cartridge with $6 \mathrm{~mL}$ methanol at $2 \mathrm{~mL} / \mathrm{min}$. The sample was then dried with pointed nitrogen gas before reconstituting in hexane. A $100 \mu \mathrm{L}$ aliquot of a recovery standard (TCMX, $1.00 \mathrm{ppm}$ ) was added to the final sample before GC-MS analysis.

\subsubsection{Sample Analysis by GC-MS}

Extracts from the three matrices were analyzed using a Thermo Trace Ultra GC interfaced with a Thermo DSQ Mass Spectrometer operated in selected ion monitoring mode (Table 2.2) at $70 \mathrm{eV}$. A minimum of two ions were scanned for each analyte. For Irgarol, the total ion current of the three major fragments was used for quantitation and 
confirmation (Gardinali et al. 2004). Two $\mu \mathrm{L}$ of extract were injected in splitless mode. Analyte separation was carried out using a $30 \mathrm{~m}$ x $250 \mu \mathrm{m}$ I.D. x $0.25 \mu \mathrm{m}$ film thickness DB5-ms fused silica capillary column (Agilent, Folsom, CA). Helium was used as carrier gas and flowed at a constant rate of $1.2 \mathrm{~mL} / \mathrm{min}$. The $\mathrm{GC}$ oven initial temperature was set to $100^{\circ} \mathrm{C}$, held for one minute, ramped at a rate of $15{ }^{\circ} \mathrm{C} / \mathrm{min}$ to a final temperature of $300^{\circ} \mathrm{C}$ and held for 1.33 minutes (Zamora-Ley et al. 2006). The MS transfer line and ion source temperatures were $280{ }^{\circ} \mathrm{C}$ and $250{ }^{\circ} \mathrm{C}$, respectively. The total run time per sample was 13 minutes. Irgarol eluted at 12 minutes, M1 at 10.25 minutes, and M3 at 11.0 minutes. Batch quality control included analysis of fortified blanks (all analytes $<$ MPC), fortified samples (recovered $70-120 \%$ ) and replicate samples ( $\pm 30 \%$ RPD). A 9 point linear control curve (minimum $\mathrm{R}^{2}=0.990$ ) was used for all batches (Gardinali et al. 2004; Zamora-Ley et al. 2006). Calibration curves were generated by plotting the concentration ratio of the analyte and surrogate versus the area ratio of the analyte and surrogate (Maxey 2006).

Table 0.2 SIM mass table for analysis.

\begin{tabular}{l|c|c|c|c}
\hline \multicolumn{1}{c|}{ Analyte } & $\begin{array}{c}\text { Quantitation } \\
\text { Ion }\end{array}$ & $\begin{array}{c}\text { Confirmation } \\
\text { Ion 1 }\end{array}$ & $\begin{array}{c}\text { Confirmation } \\
\text { Ion 2 }\end{array}$ & $\begin{array}{c}\text { Confirmation } \\
\text { Ion 3 }\end{array}$ \\
\hline TCMX (IS) & 244 & 242 & 246 & --- \\
Atrazine-d5 & 205 & 222 & --- & --- \\
Atrazine & 200 & 215 & 217 & --- \\
M1 & 213 & 198 & 157 & --- \\
M3 & 270 & 214 & --- & --- \\
Irgarol & TIC $^{\text {a }}$ & 182 & 238 & 253 \\
\hline
\end{tabular}

a. Total Ion Current 


\subsubsection{Method Performance and Statistical Analysis}

Analytes were quantified using a nine-point calibration curve. Calibration solutions ranged from $2.5 \mathrm{pg} / \mu \mathrm{L}$ to $1000 \mathrm{pg} / \mu \mathrm{L}$. R-squared values for all calibration curves for each sample set met the criteria of greater than 0.995 to pass method quality assurance/control parameters (Maxey 2006).

Analytical performance of aqueous samples was verified by running artificial seawater blanks, consisting of DDI water with 20 grams of sodium chloride, and fortified blanks. Fortified blanks were spiked with $100 \mu \mathrm{L}$ of a $1 \mathrm{ppm}$ mixture of all the analytes. Sediment blanks consisted of DE powder while fortified sediment blanks were spiked with $200 \mu \mathrm{L}$ of a $1 \mathrm{ppm}$ mixture of all analytes to assess the recovery performance of the extraction method. Recoveries for surrogate and target compounds are listed in Table 2.3. Method detection limits (MDL) for surface water samples and sediments were set at 1 $\mathrm{ng} / \mathrm{L}$ and $1 \mathrm{ng} / \mathrm{g}$, respectively as determined previously (Maxey 2006). 
Table 0.3 Recoveries of target compounds in fortified blanks.

\begin{tabular}{|c|c|c|c|c|}
\hline Matrix & Compound & \% Recovery & \% R.S.D ${ }^{a}$ & \# of samples \\
\hline \multirow{4}{*}{ Surface Water } & Atrazine & 94 & 25 & 7 \\
\hline & Irgarol & 103 & 14 & 7 \\
\hline & M1 & 95 & 22 & 7 \\
\hline & M3 & 99 & 12 & 7 \\
\hline \multirow{4}{*}{ Sediment } & Atrazine & 80 & 34 & 4 \\
\hline & Irgarol & 90 & 23 & 4 \\
\hline & M1 & 80 & 30 & 4 \\
\hline & M3 & 97 & 18 & 3 \\
\hline \multirow{4}{*}{$\begin{array}{c}\text { SAV } \\
\text { (automated) }\end{array}$} & Atrazine & 93 & 33 & 4 \\
\hline & Irgarol & 89 & 23 & 4 \\
\hline & M1 & 97 & 14 & 4 \\
\hline & M3 & 71 & 42 & 4 \\
\hline \multirow{4}{*}{ SAV (manual) } & Atrazine & 85 & 15 & 5 \\
\hline & Irgarol & 108 & 26 & 5 \\
\hline & M1 & 116 & 12 & 5 \\
\hline & M3 & 90 & 33 & 5 \\
\hline
\end{tabular}

a. Relative Standard Deviation (Standard Deviation/Average*100)

b. Surrogate recoveries were calculated using samples, blanks, and fortified blanks

\subsection{Results}

\subsubsection{Solid Phase Extraction Method Comparison}

Method performance of the standard manual SPE method involving Oasis HLB Plus cartridges and vacuum was compared to the new automated method developed using smaller Oasis cartridges in a Zymark Rapid Trace Workstation. Similar to sediment fortified blanks, 1 ppm of surrogate and spiking solution was added to DE and extracted 
using ASE before processing with the corresponding SPE method. The differences in the two analyses are represented by the percent relative standard deviation (R.S.D.) between the replicates. Percent relative standard deviation values for the manual method are higher than those of the automated analysis (Table 2.4). This is most likely the result of a closely controlled solvent rate passing through the cartridges in the automated method compared to the approximated solvent flow rate in the manual method.

Methanol and methylene chloride were compared to determine the best eluting solvent for the automated method. Two ppm of surrogate and $1 \mathrm{ppm}$ of spiking solution was directly added to sample tubes and processed in triplicate. Samples were extracted with the same method differing in eluting solvent only. The best eluting solvent for Atrazine-d5 was methylene chloride. The preferred eluting solvent for Irgarol was methanol with an R.S.D. of $3 \%$, compared to methylene chloride at $20 \%$. M1 was best recovered using methanol while M3 was recovered better when methylene chloride was used (Table 2.5). Methanol was determined to be the best eluting solvent for extracting herbicides by automated SPE using the Zymark Rapid Trace Workstation.

Table 0.4 Recoveries of fortified blanks, SPE method.

\begin{tabular}{|c|c|c|c|}
\hline Method & Compound & \% Recovery & \% R.S.D. \\
\hline \multirow{4}{*}{ Automated } & Atrazine & 102 & 23 \\
\hline & M1 & 121 & 34 \\
\hline & M3 & 78 & 35 \\
\hline & Irgarol & 89 & 20 \\
\hline \multirow{4}{*}{ Manual } & Atrazine & 85 & 7.3 \\
\hline & M1 & 114 & 46 \\
\hline & M3 & 91 & 42 \\
\hline & Irgarol & 112 & 34 \\
\hline
\end{tabular}


Table 0.5 Recovery in fortified blanks, automated SPE method.

\begin{tabular}{|c|c|c|c|c|}
\hline Eluting Solvent & Compound & Recovery (ppm) & \% Recovery & \% R.S.D \\
\hline \multirow{4}{*}{ Methanol } & Atrazine & 128 & 128 & 2.1 \\
\hline & M1 & 109 & 109 & 4.3 \\
\hline & M3 & 37.8 & 37.8 & 11 \\
\hline & Irgarol & 121 & 121 & 3.0 \\
\hline \multirow{4}{*}{$\begin{array}{l}\text { Methylene } \\
\text { Chloride }\end{array}$} & Atrazine & 76.9 & 76.9 & 6.0 \\
\hline & M1 & 43.8 & 43.8 & 11 \\
\hline & M3 & 51.9 & 51.9 & 33 \\
\hline & Irgarol & 76.4 & 76.4 & 20 \\
\hline
\end{tabular}




\subsubsection{Hydrological Parameters}

Hydrological parameters did not vary significantly between sampling locations within sampling sites CG, KLH and MR (Table 2.6). Class III water bodies, such as MR and $\mathrm{CG}$ are intended to provide recreational opportunities and support a healthy and balanced population of wildlife. Class III designation requires dissolved oxygen within the water column to average greater than $5.0 \mathrm{mg} / \mathrm{L}$ and to never drop below $4.0 \mathrm{mg} / \mathrm{L}$. Rapid changes in dissolved oxygen or levels below $2 \mathrm{mg} / \mathrm{L}$ results in severe physiological stress or death to aquatic organisms (F.D.o.E.P. 2001). Miami River exhibited substandard dissolved oxygen levels of $2.38 \pm 0.59$ during the 2008 wet season. This data indicates that MR does not meet the designated use outlined by Department of Protection policy despite the highest level of protection it is afforded.

KLH in 2008 and CG in 2007 and 2008 exhibited acceptable levels of dissolved oxygen. In 2007 dissolved oxygen was $4.72 \pm 0.68 \mathrm{mg} / \mathrm{L}$, between the lower limit of 4 $\mathrm{mg} / \mathrm{L}$ and the acceptable lower threshold of $5 \mathrm{mg} / \mathrm{L}$. This reduced dissolved oxygen is probably due to increased boating activity during this month (Table 2.). 
Table 0.6 Hydrological parameters for CG, KLH and MR.

\begin{tabular}{|c|c|c|c|c|c|c|c|c|c|c|}
\hline $5 / 10 / 07$ & CG01 & CG02 & CG03 & CG04 & CG05 & CG06 & CG07 & CG08 & AVG & SD \\
\hline Temp. $\left({ }^{\circ} \mathrm{C}\right)$ & 25.6 & 25.5 & 25.7 & 26.4 & 27.0 & 26.6 & 25.2 & 26.2 & 26.0 & 0.62 \\
\hline Salinity (ppt) & 34.9 & 35.2 & 35.2 & 35.1 & 35.0 & 35.1 & 35.0 & 35.0 & 35.1 & 0.11 \\
\hline $\mathrm{O}_{2}(\mathrm{mg} / \mathrm{L})$ & 6.00 & 6.31 & 7.13 & 6.54 & 6.46 & 6.03 & 7.05 & 5.98 & 6.44 & 0.45 \\
\hline $\mathrm{pH}$ & 8.32 & 8.33 & 8.35 & 8.28 & 8.26 & 8.22 & 8.36 & 8.27 & 8.30 & 0.05 \\
\hline $6 / 6 / 07$ & KLH01 & KLH02 & KLH03 & KLH04 & KLH05 & KLH06 & KLH07 & & AVG & SD \\
\hline Temp. $\left({ }^{\circ} \mathrm{C}\right)$ & 28.2 & 28.6 & 28.8 & 28.9 & 29.3 & 29.2 & 29.4 & & 28.9 & 0.43 \\
\hline Salinity (ppt) & 31.0 & 31.1 & 31.0 & 31.2 & 31.2 & 31.3 & 31.3 & & 31.2 & 0.13 \\
\hline $\mathrm{O}_{2}(\mathrm{mg} / \mathrm{L})$ & 5.78 & 5.20 & 4.23 & 3.89 & 4.12 & 4.81 & 5.01 & & 4.72 & 0.68 \\
\hline $\mathrm{pH}$ & 8.08 & 8.11 & 8.12 & 8.13 & 8.15 & 8.23 & 8.25 & & 8.15 & 0.06 \\
\hline $2 / 4 / 08$ & CG01 & CG02 & CG03 & CG04 & CG05 & CG06 & CG07 & CG08 & AVG & SD \\
\hline Temp. $\left({ }^{\circ} \mathrm{C}\right)$ & 25.7 & 25.3 & 23.6 & 24.2 & 22.2 & 22.2 & 21.5 & 25.4 & 23.8 & 1.65 \\
\hline Salinity (ppt) & 45.4 & 42.7 & 43.1 & 33.3 & 45.7 & 41.7 & 48.4 & 32.0 & 41.5 & 5.88 \\
\hline $\mathrm{O}_{2}(\mathrm{mg} / \mathrm{L})$ & 4.60 & 3.54 & 5.00 & 5.09 & 3.76 & 5.26 & 5.76 & 7.51 & 5.07 & 1.24 \\
\hline $\mathrm{pH}$ & 7.08 & 7.07 & 7.14 & 7.23 & 7.35 & 8.11 & 7.12 & 6.97 & 7.26 & 0.36 \\
\hline $1 / 25 / 08$ & KLH01 & KLH02 & KLH03 & KLH04 & KLH05 & KLH06 & KLH07 & KLH08 & AVG & SD \\
\hline Temp. $\left({ }^{\circ} \mathrm{C}\right)$ & 22.8 & 23.0 & 22.9 & 22.9 & 22.9 & 22.7 & 22.7 & 23.0 & 22.9 & 0.12 \\
\hline Salinity (ppt) & 34.5 & 34.6 & 34.8 & 34.9 & 35.1 & 35.2 & 35.1 & 35.0 & 34.9 & 0.25 \\
\hline $\mathrm{O}_{2}(\mathrm{mg} / \mathrm{L})$ & 4.80 & 4.72 & $\mathrm{~N} / \mathrm{A}$ & 5.89 & 5.78 & 6.30 & 7.47 & 5.17 & 5.73 & 0.96 \\
\hline $\mathrm{pH}$ & 7.74 & 7.75 & 7.72 & 7.85 & 7.95 & 7.95 & 8.00 & 7.91 & 7.86 & 0.11 \\
\hline $5 / 20 / 08$ & MR95 & MRBP & MRBY & MRCP & MRMS & MRNS & MRSF & MRYC & AVG & SD \\
\hline Temp. $\left({ }^{\circ} \mathrm{C}\right)$ & 26.7 & 25.4 & 28.6 & 26.9 & 27.0 & 27.3 & 27.2 & 26.9 & 27.0 & 0.88 \\
\hline Salinity (ppt) & 22.5 & 31.3 & 16.9 & 19.1 & 21.5 & 22.6 & 22.1 & 17.6 & 21.7 & 4.48 \\
\hline $\mathrm{O}_{2}(\mathrm{mg} / \mathrm{L})$ & 2.77 & 3.22 & 1.46 & 1.99 & 2.68 & 2.74 & 1.77 & 2.40 & 2.38 & 0.59 \\
\hline Depth (m) & 18.8 & 18.0 & 18.9 & 18.5 & 17.4 & 17.3 & 12.0 & 16.8 & 17.2 & 2.24 \\
\hline
\end{tabular}




\subsubsection{Miami River}

Table 0.7 Results from the Miami River, May 20, 2008.

\begin{tabular}{l|cccc}
\hline Location & Irgarol (ng/L) & M1 (ng/L) & Atrazine (ng/L) \\
\hline MR95 & 52.1 & 26.7 & 18.8 \\
MRBP & 28.4 & 19.4 & 19.4 \\
MRBY & 12.0 & 12.9 & 11.5 \\
MRCP & 20.8 & 12.3 & 10.6 \\
MRMS & 41.9 & 35.6 & 13.8 \\
MRNS & 39.2 & 17.8 & 13.4 \\
MRSF & 33.7 & 23.6 & 21.0 \\
MRYC & 40.0 & 40.1 & 18.2 \\
\hline \multicolumn{1}{c}{ Range } & $12.0-52.1$ & $12.3-40.1$ & $10.6-21.0$ \\
\hline
\end{tabular}

Miami River was sampled at eight different locations throughout the river starting at the mouth of the river and inward. Atrazine and M1 levels were higher in MR than all other areas sampled (KLH and CG). M3, a byproduct of Irgarol manufacturing, was not detected. Irgarol and M1 concentration ranges were similar, $12.0 \mathrm{ng} / \mathrm{L}$ to $52.1 \mathrm{ng} / \mathrm{L}$ and $12.3 \mathrm{ng} / \mathrm{L}$ to $40 \mathrm{ng} / \mathrm{L}$ respectively (Table 2.7). These high levels of M1 are possibly a result of pollution-induced murkiness of the water preventing further photodegradation of the metabolite. Miami River $90^{\text {th }}$ percentile for Irgarol in 2008 determined in this study $(69 \mathrm{ng} / \mathrm{L})$ is 2.8 times lower than the plant toxicity $10^{\text {th }}$ percentile (Hall et al. 2009). Percentile graphs for Irgarol and M1 are shown in Figure 2.8 and 2.9 , respectively. 


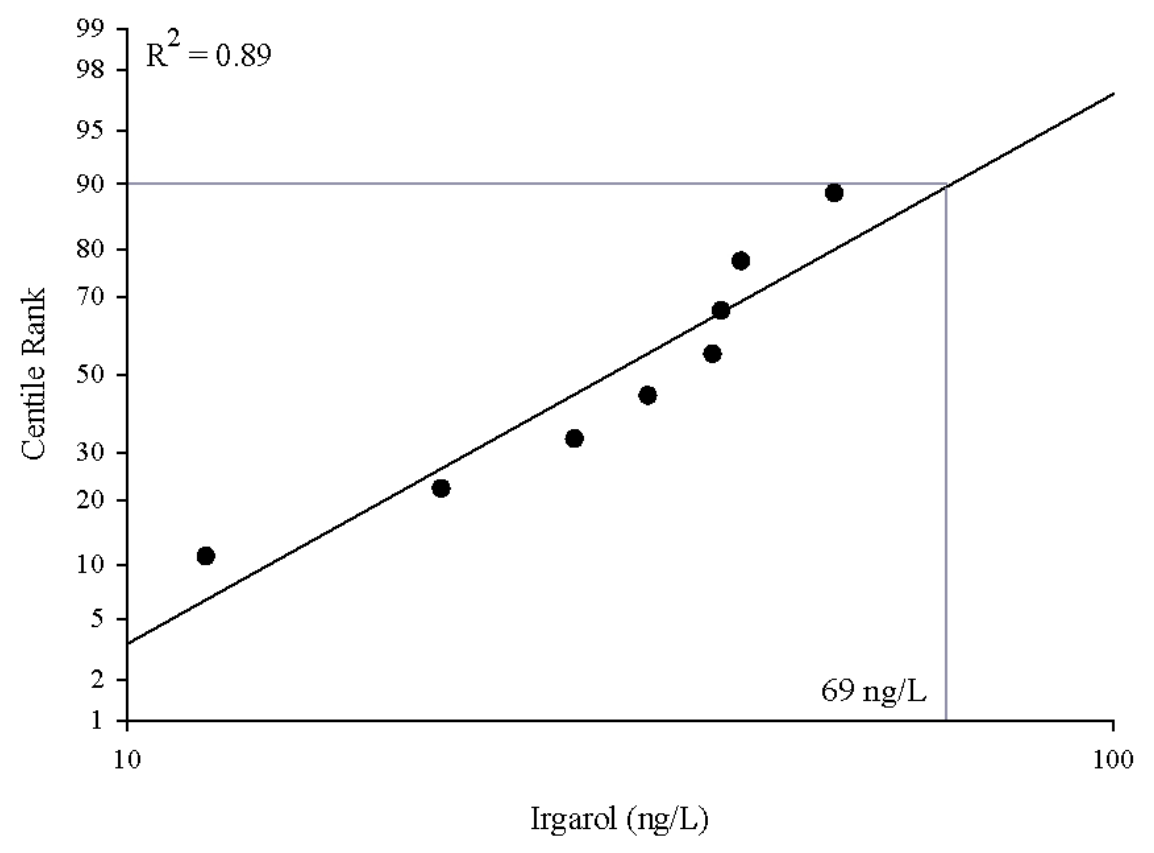

Figure 0.6 Percentile graph for Irgarol at Miami River, 2008.

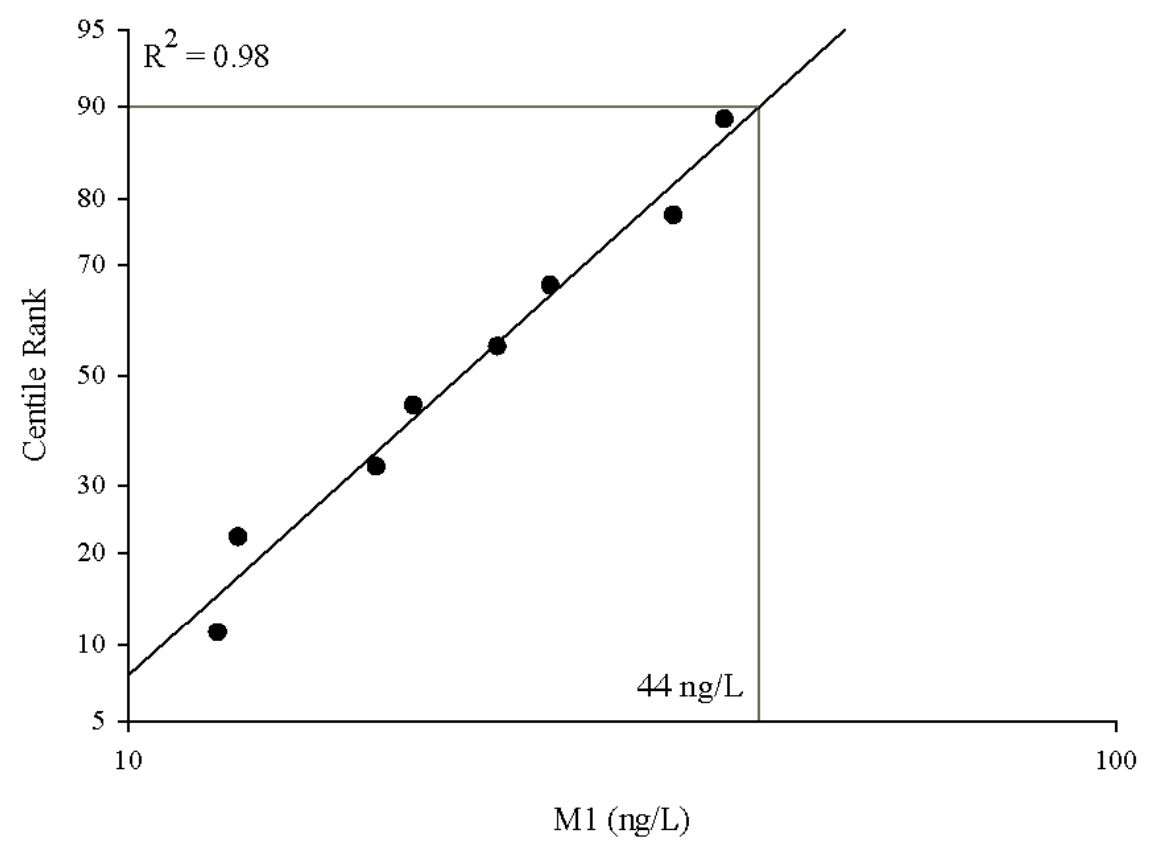

Figure 0.7 Percentile graph for M1 at Miami River, 2008. 


\subsubsection{Coconut Grove}

Irgarol concentrations have been consistent between 2006, 2007 and 2008 (APPENDIX C, Table 2.8). Values varied greatest at CG04 and CG08 with maximum values in May 2007. Lowest values were found in CG07 and CG08, possibly because of higher water turnover occurring at these sites compared to the others within CG. The structure of the marina within CG is open with a few small islands sprinkling the area creating potential spots for decreased water turnover. The sampled areas, CG04 and CG05, are two such sites; they are located close to dock-stored water vessels and partially enclosed by an island South-east to the sites. Consistent with this, Irgarol levels at CG for both 2007 and 2008 are highest at these CG04 and CG05 compared to the other CG sites sampled (Figure 2.10). Atrazine concentrations of Irgarol in that they are similar in May 2007 and February 2008 and are consistent with coastal levels of Atrazine (Gardinali et al. 2004).

The trend of M1 concentrations throughout CG resembles that of Irgarol. Lowest values are found at CG07 and CG08. Surface water concentrations of the metabolite M1 are approximately half those of Irgarol at all sites and varied much less than Irgarol throughout CG. The highest value obtained for CG was in 2008 at $34.7 \mathrm{ng} / \mathrm{L}$ and the lowest value was at $10.2 \mathrm{ng} / \mathrm{L}$ in 2007 . The metabolite M3 was only detectable within CG in the spring of 2007 at a maximum concentration of $3.10 \mathrm{ng} / \mathrm{L}$ (Table 2.8).

There does not appear drastic seasonal variation of Irgarol and M1 at CG. The average concentration of Irgarol is $48.9 \mathrm{ng} / \mathrm{L}$ and $34.6 \mathrm{ng} / \mathrm{L}$ in the wet and dry season, respectively. This is probably because of year-round submerged storage of water-crafts. 
The Irgarol $90^{\text {th }}$ percentile for CG is approximately 2.5 times lower $(76 \mathrm{ng} / \mathrm{L})$ than the plant $10^{\text {th }}$ percentile (Figure 2.10 ). The M1 $90^{\text {th }}$ percentile is approximately 165 times lower than the plant $10^{\text {th }}$ percentile (Figure 2.11). Therefore CG is not at risk for plant toxicity. Concentrations of Irgarol in 2006, 2007 and 2008 are not significantly different, but a trend for increasing levels of Irgarol in the water column seems likely.

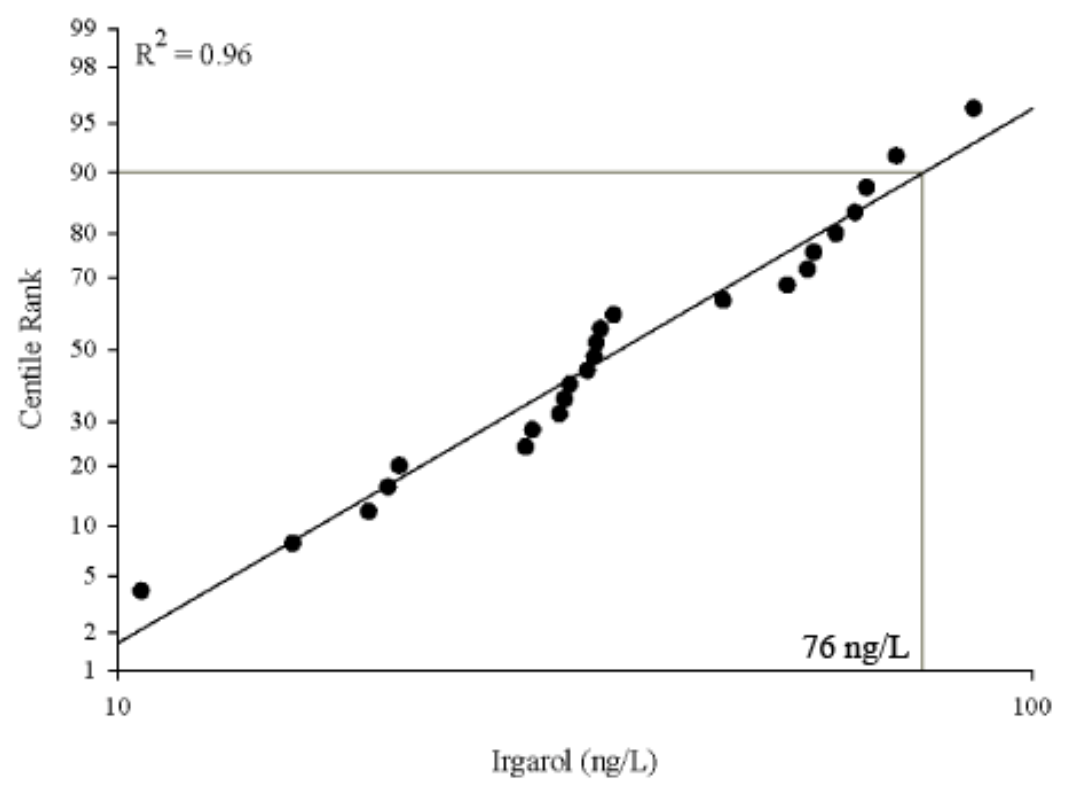

Figure 0.8 Percentile graph for Irgarol at Coconut Grove, 2006 - 2008. 


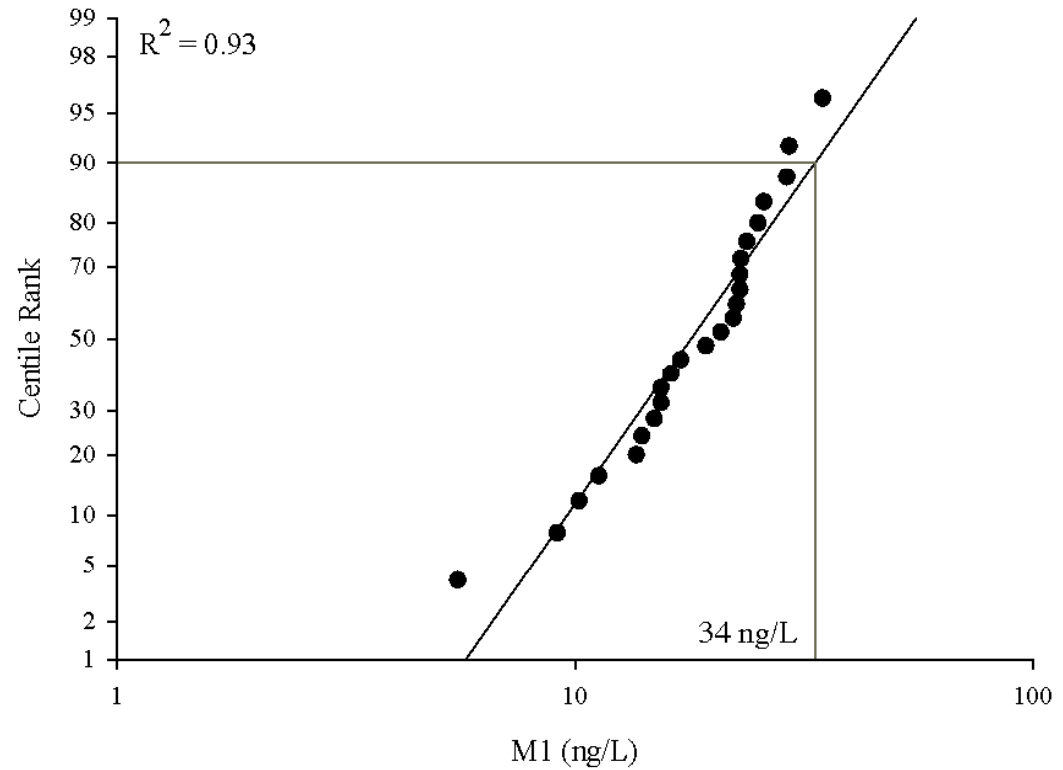

Figure 0.9 Percentile graph for M1 at Coconut Grove, 2006 - 2008. 
Table 0.8 Summary of results from CG surface waters.

\begin{tabular}{|c|c|c|c|c|c|c|c|c|c|c|}
\hline & Compound & CG01 & CG02 & CG03 & CG04 & CG05 & CG06 & CG07 & CG08 & Range \\
\hline \multirow{4}{*}{$\frac{\hat{0}}{0}$} & Irgarol (ng/L) & 45.9 & 31.2 & 33.7 & 86.3 & 64.0 & 30.8 & 28.4 & 71.0 & $28.4-86.3$ \\
\hline & M1 (ng/L) & 29.0 & 15.4 & 19.3 & 22.9 & 25.8 & 22.9 & 10.2 & 23.0 & $10.2-29.0$ \\
\hline & M3 (ng/L) & 3.10 & 1.19 & N.D. & N.D. & N.D. & N.D. & 2.4 & N.D. & N.D. - 3.10 \\
\hline & Atrazine (ng/L) & 6.92 & 7.2 & 5.82 & 7.67 & 8.37 & 5.52 & 6.3 & 7.43 & $5.82-8.37$ \\
\hline \multirow{4}{*}{ 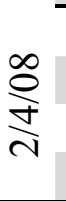 } & Irgarol (ng/L) & 33.2 & 34.8 & 19.7 & 54.0 & 65.9 & 33.4 & 15.5 & 20.3 & $19.7-65.9$ \\
\hline & M1 (ng/L) & 25.1 & 17.0 & 34.7 & 22.2 & 29.3 & 14.0 & 14.9 & 11.3 & $11.3-34.7$ \\
\hline & M3 (ng/L) & N.D. & N.D. & N.D. & N.D. & N.D. & N.D. & N.D. & N.D. & N.D. \\
\hline & Atrazine (ng/L) & N.D. & N.D. & N.D. & N.D. & N.D. & N.D. & N.D. & 2.7 & N.D. -2.7 \\
\hline
\end{tabular}

N.D. $=$ Not Detected, below LOD $(<1 \mathrm{ng})$

Table 0.9 Summary of results from KLH surface waters.

\begin{tabular}{|c|c|c|c|c|c|c|c|c|c|c|}
\hline & Compound & KLH01 & KLH02 & KLH03 & KLH04 & KLH05 & KLH06 & KLH07 & KLH08 & Range \\
\hline & Irgarol (ng/L) & 241 & 117 & 28.7 & 12.2 & 8.20 & 9.50 & 5.70 & N.S. & $5.70-241$ \\
\hline 2 & M1 (ng/L) & 50.0 & 31.1 & 10.7 & 2.90 & 3.10 & N.D. & N.D. & N.S. & N.D. -50.0 \\
\hline & M3 (ng/L) & N.D. & N.D. & N.D. & N.D. & N.D. & N.D. & N.D. & N.S. & N.D. \\
\hline & Atrazine $(\mathrm{ng} / \mathrm{L})$ & 2.52 & 2.03 & 1.30 & N.D. & N.D. & N.D. & N.D. & N.S. & N.D. -2.52 \\
\hline & Irgarol (ng/L) & 102 & 94.9 & 20.3 & 10.3 & 9.70 & 7.00 & 8.90 & 25.4 & $7.00-102$ \\
\hline 2 & M1 (ng/L) & 22.1 & 17.7 & 6.10 & 4.00 & 3.60 & 2.00 & 4.60 & 7.30 & $2.00-22.1$ \\
\hline S & M3 (ng/L) & N.D. & N.D. & N.D. & N.D. & N.D. & N.D. & N.D. & N.D. & N.D. \\
\hline & Atrazine (ng/L) & N.D. & N.D. & N.D. & N.D. & N.D. & N.D. & N.D. & N.D. & N.D. \\
\hline
\end{tabular}

N.D. $=$ Not Detected 


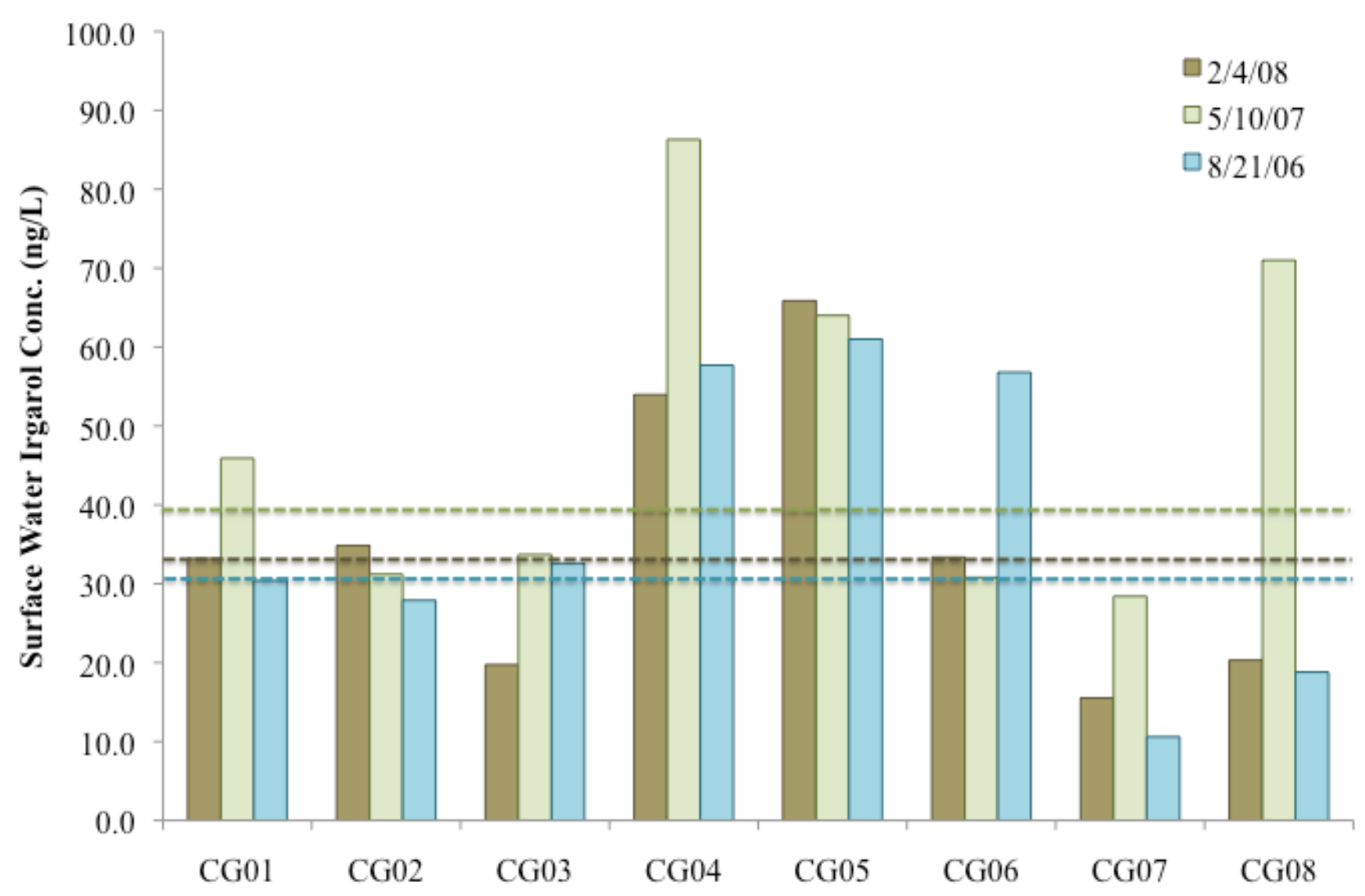

Figure 0.10 Fluctuations of Irgarol at CG, 2006 - 2008.

Medians for 2006, 2007 and 2008 (31.5 ng/L, $39.8 \mathrm{ng} / \mathrm{L}$ and $33.3 \mathrm{ng} / \mathrm{L}$, respectively) are indicated with a dashed line. Medians are not statically significant $(\mathbf{p}>0.35)$. 


\subsubsection{Key Largo Harbor}

Surface water Irgarol concentrations are slightly higher in wet (2007) than in dry (2008) season (Table 2.9) but are not significantly different. A trend for increasing levels of Irgarol in the water column during the wet season (2007) compared to the dry season (2008) mirrors the preference for wet slip storage in the wet season and dry slip storage in the dry season (Figure 2.13).

Turnover rates are lowest at KLH01 (Figure 2.4) resulting in highest levels of Irgarol and M1 at KLH01, the highest end of the canal system with the least water circulation. Concentrations of Irgarol rapidly decrease along the main navigational channel approaching open water from $241 \mathrm{ng} / \mathrm{L}$ at KLH01 to $5.7 \mathrm{ng} / \mathrm{L}$ at KLH07 and 102 $\mathrm{ng} / \mathrm{L}$ to $7 \mathrm{ng} / \mathrm{L}$ in 2007 and 2008, respectively (Table 2.9). These data is representative of the enclosed canal-like design of KLH. Interestingly, the KLH $90^{\text {th }}$ percentile for Irgarol, $392 \mathrm{ng} / \mathrm{L}$, exceeds the plant toxicity $10^{\text {th }}$ percentile (Figure 2.13 ) but the M1 $90^{\text {th }}$ percentile does not (Figure 2.14). 


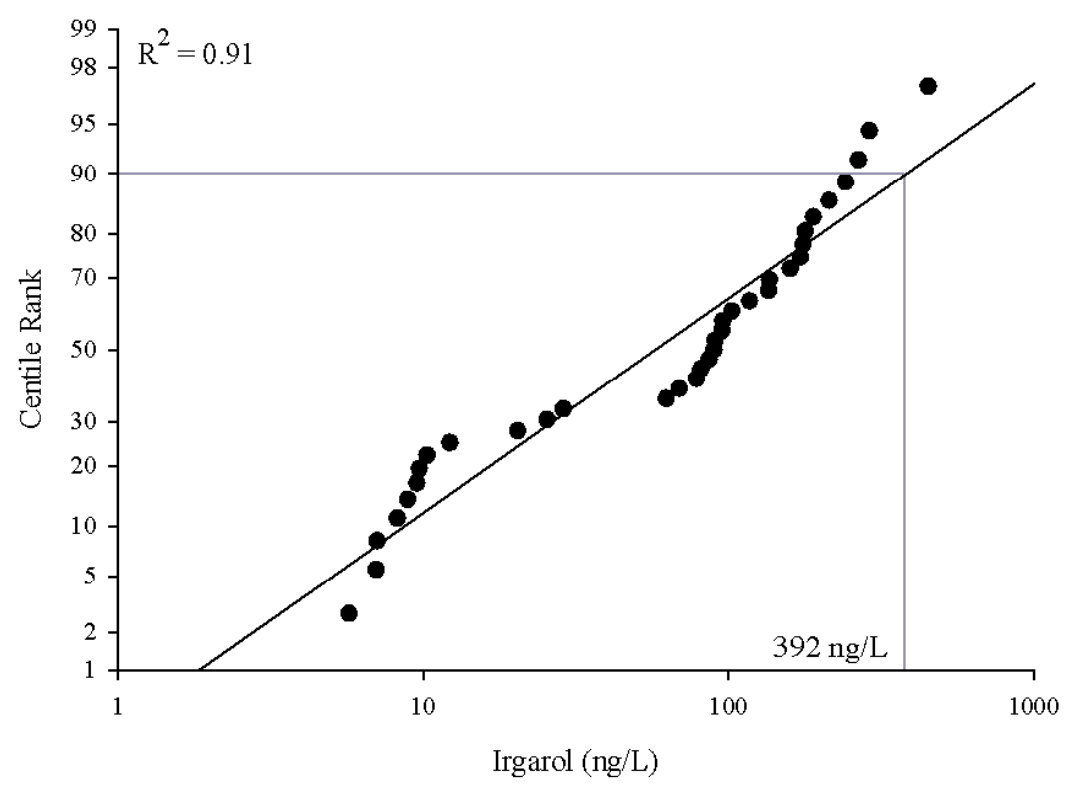

Figure 0.11 Percentile graph for Irgarol at KLH, 2004 - 2008.

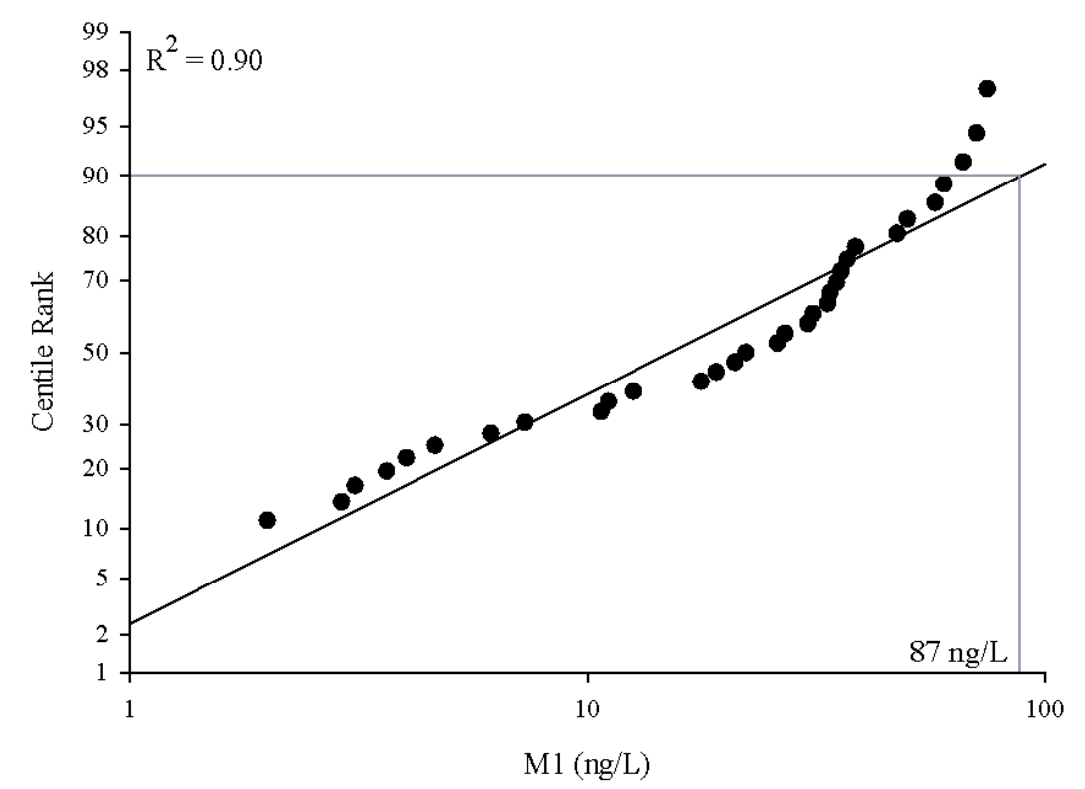

Figure 0.12 Percentile graph for M1 at KLH, 2004 - 2009. 


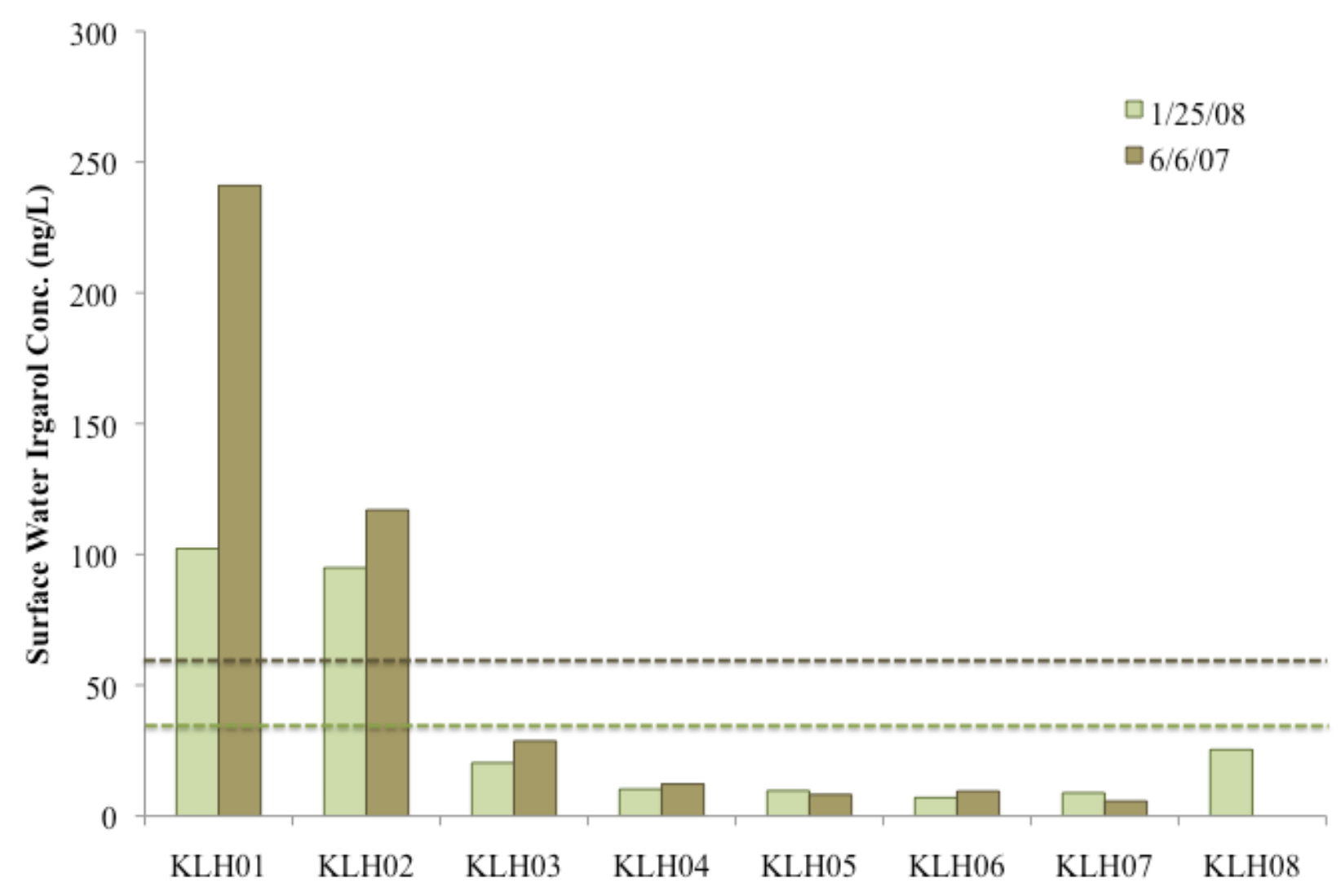

Figure 0.13 Concentration of Irgarol at KLH in 2007 - 2008.

Averages for 2007 and 2008 (60 ng/L and $35 \mathrm{ng} / \mathrm{L}$, respectively) are indicated with a dashed line. Irgarol concentrations are not statically significant $(p>0.35)$ as determined by hetereoscedastic $T$-test. 


\subsubsection{Chicken Key}

Chicken Key is a small island in Biscayne Bay located approximately $12.8 \mathrm{~km}$ south of CG and surrounded by waters free of Irgarol contamination. Surface waters were sampled throughout the transplant study, described in chapter 3, to ensure no detectable levels of Irgarol or its daughter metabolites were present. Surface waters sampled off the North-east coast of CK had no detectable levels of Irgarol, M1 and M3. Interestingly, Atrazine was detected at $7.2 \pm 4.0 \mathrm{ng} / \mathrm{L}$ throughout July and August of 2008. This value is comparable to $\mathrm{CG}(7.9 \pm 0.90 \mathrm{ng} / \mathrm{L})$ (Table 2.10) and consistent with coastal levels of Atrazine (Gardinali et al. 2004).

Table 0.10 CK surface waters, July - August 2008.

\begin{tabular}{rl|ccccccc}
\hline Location & Herbicide & $\mathbf{7 / 1 / 0 8}$ & $\mathbf{7 / 8 / 0 8}$ & $\mathbf{7 / 1 8 / 0 8}$ & $\mathbf{8 / 1 / 0 8}$ & $\mathbf{8 / 1 2 / 0 8}$ & Average & SD \\
\hline \multirow{2}{*}{ CK } & $\begin{array}{l}\text { Irgarol } \\
(\mathrm{ng} / \mathrm{L})\end{array}$ & N.D. & N.D. & N.D. & N.D. & N.D. & N.D. & \\
& $\begin{array}{l}\text { Atrazine } \\
\text { (ng/L) }\end{array}$ & 8.8 & 9.1 & 7.9 & 10.2 & 0.2 & 7.2 & 4 \\
\hline CG04 & $\begin{array}{l}\text { Atrazine } \\
(\mathrm{ng} / \mathrm{L})\end{array}$ & 7.9 & 9.1 & 8.4 & 6.8 & 7.3 & 7.9 & 0.90 \\
\hline N.D. $=<1 \mathrm{ng} / \mathrm{L}$
\end{tabular}




\subsubsection{Comparison between locations}

Irgarol and its metabolites M1 and M3 were measured by GC-MS from surface waters collected at four locations in South-east Florida. Concentrations of these compounds in surface water varied most greatly for KLH in both 2007 and 2008 compared to CG. Minimum and maximum values were similar between years and seasons. The highest value at CG was 86.3 and $65.9 \mathrm{ng} / \mathrm{L}$ and for KLH was 241.0 and $102 \mathrm{ng} / \mathrm{L}$ in 2007 and 2008, respectively. Consistent with the smaller range of value obtained from CG compared to KLH, the lowest value at CG was 28.4 and $18.7 \mathrm{ng} / \mathrm{L}$ and for KLH was 5.70 and $7.00 \mathrm{ng} / \mathrm{L}$ for 2007 and 2008 respectively. These data agree with previous reports (Gardinali et al. 2004; Maxey 2006; Zamora-ley et al. 2004).

The $90^{\text {th }}$ percentile for Irgarol exposure was highest for KLH, the only location to exceed the $10^{\text {th }}$ percentile plant toxicity. South-east Florida $90^{\text {th }}$ percentile for CG, KLH and MR of $184 \mathrm{ng} / \mathrm{L}$ is below the $10^{\text {th }}$ percentile plant toxicity benchmark (Figure 2.16). The M1 $90^{\text {th }}$ percentile for South-east Florida of $59 \mathrm{ng} / \mathrm{L}$ does not exceed the plant toxicity $10^{\text {th }}$ percentile (Figure 2.17). 


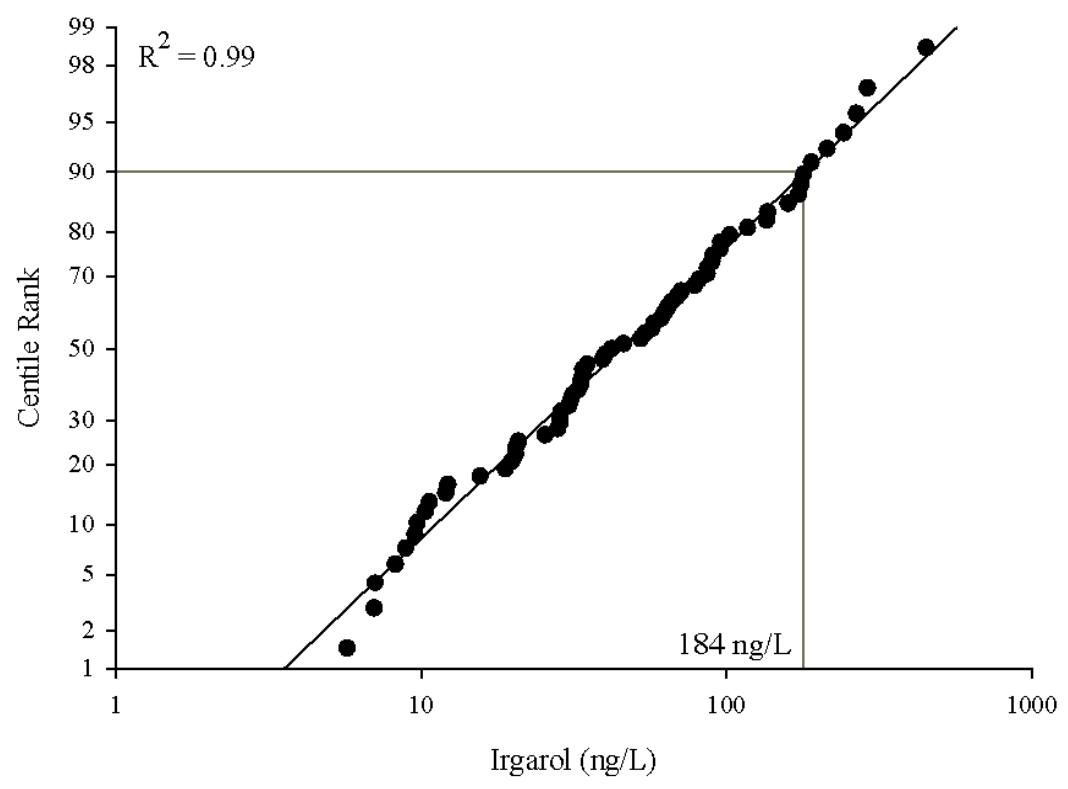

Figure 0.14 Irgarol percentile graphs for, 2004-2008.

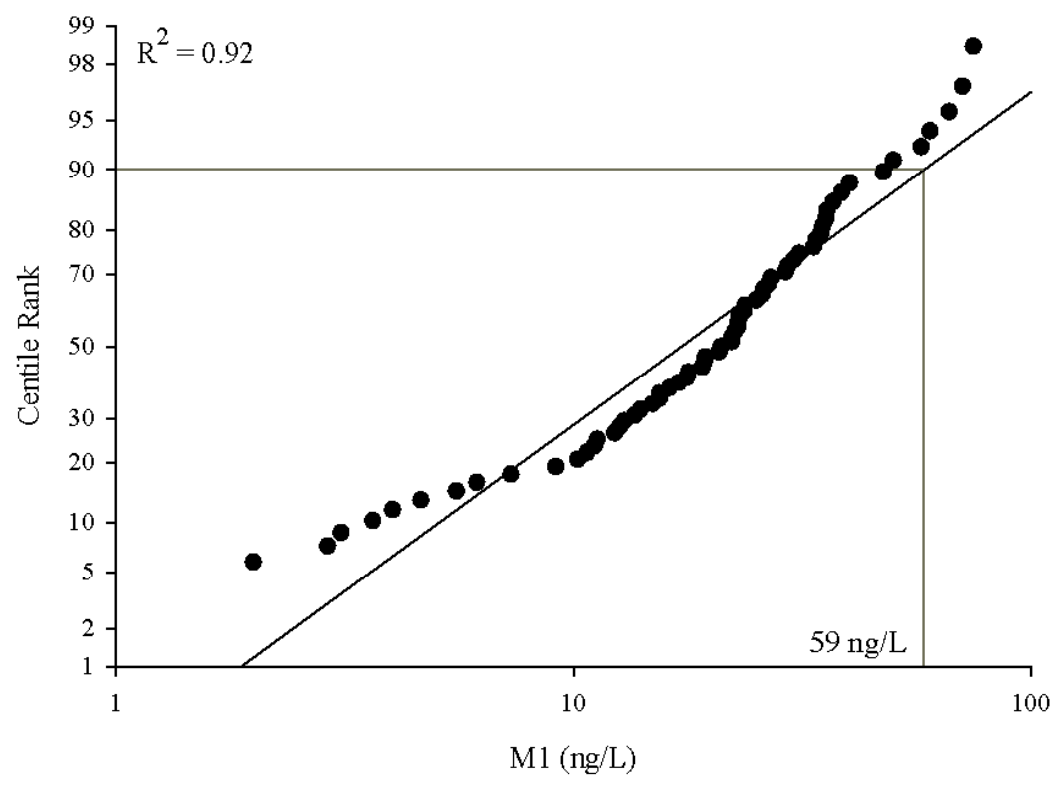

Figure 0.15 M1 percentile graphs for, 2004-2008. 


\subsubsection{Sediment Contamination}

Sediment type differed between KLH and CG. Sediment collected at KLH was composed of large grain sand and small pieces of bivalve shell with an overall light brown-beige coloration. These two sediment types had the same ability to accumulate Irgarol and its metabolites.

Irgarol was detected at one site within CG during the wet season of 2007 at 1.40 $\mathrm{ng} / \mathrm{L}$ and not detected during the dry season of 2008. It was also detected at only one site sampled within 2008, but not in 2007 (Table 2.11).

The metabolite M1 was not detected in any of the sediment samples collected. Irgarol was detected in one sediment sample collected from G04. This is also the same site with the highest detected levels of Irgarol in the surface water for 2007.

These data show a clear affinity of Irgarol for the dissolved phase in agreement with previous research (Konstantinou et al. 2004) but in disagreement with expected accumulation based on the $\mathrm{K}_{\mathrm{OW}}$.

Table 0.11 Sediment concentrations (ng/g), CG and KLH.

\begin{tabular}{|c|c|c|c|c|c|c|c|c|}
\hline Year & CG01 & CG02 & CG03 & CG04 & CG05 & CG06 & CG07 & CG08 \\
\hline $5 / 10 / 07$ & N.D. & N.D. & N.D. & 1.4 & N.D. & N.D. & N.D. & N.D. \\
\hline $2 / 4 / 08$ & N.D. & N.D. & N.D. & N.D. & N.D. & N.D. & N.D. & N.D. \\
\hline & KLH05 & KLH06 & KLH07 & KLH08 & & & & \\
\hline 6/6/07 & N.D. & N.D. & N.D. & N.D. & & & & \\
\hline $1 / 25 / 08$ & 2.0 & N.D. & N.D. & N.S. & & & & \\
\hline
\end{tabular}




\subsection{Conclusions}

Manual SPE method has been historically utilized for the extraction of herbicides from sediment and seagrasses. In addition to the extensive time this method requires, the use of vacuum results in difficulty standardizing sample analysis. An automated SPE method was developed using Oasis HLB cartridges to facilitate and standardize the extraction of herbicides Irgarol and M1. The Automated method for SPE is and improvement upon the manual method as indicated by the \% R.S.D. (Table 2.4) Additionally, methanol was the best Irgarol and M1 eluting solvent (Table 2.5).

The above results agree with data found in literature. Irgarol and M1 were found at $\mathrm{CG}, \mathrm{KLH}$ and MR. Atrazine was found at all locations, including the relatively isolated island, CK, located approximately 1.3 miles from the South Florida coast. Concentrations of Irgarol and M1 in surface waters ranged from $7 \mathrm{ng} / \mathrm{L}$ to $241 \mathrm{ng} / \mathrm{L}$ and from N.D. to 50 $\mathrm{ng} / \mathrm{L}$, respectively.

Concentrations in 2008 at MR, CG and KLH are compared (Figure 2.18) showing distinct differences in the distribution of Irgarol and M1 between them. Overall concentrations of Irgarol at MR were below the level shown to inhibit carbon dioxide uptake in isolated zooxanthellae (63 ng/L, benchmark "a") and to reversibly inhibit photosynthesis on whole coral (100 ng/L, benchmark "b") (Owen et al. 2002). Dispersion of Irgarol at KLH is skewed by KLH01 and KLH02, the two locations within KLH having the least water turnover. The concentration of Irgarol at KLH01 and KLH02 exceeds these two benchmarks. Despite exceeding these benchmarks the KLH Irgarol median, $15.3 \mathrm{ng} / \mathrm{L}$, is lower than $\mathrm{MR}$ and $\mathrm{CG}(36.5 \mathrm{ng} / \mathrm{L}$ and $33.3 \mathrm{ng} / \mathrm{L}$ respectively) because the majority of locations sampled within KLH had concentrations of Irgarol less 
than $26 \mathrm{ng} / \mathrm{L}$. Concentrations of Irgarol at MR and CG deviated less from the median. Only one location, CG05, within CG exceeds benchmark "a" and none exceed benchmark "b". One-way ANOVA is significant between M1 $(p=0.004)$, but not Irgarol $(p=0.56)$, in 2008 (Figure 2.16).
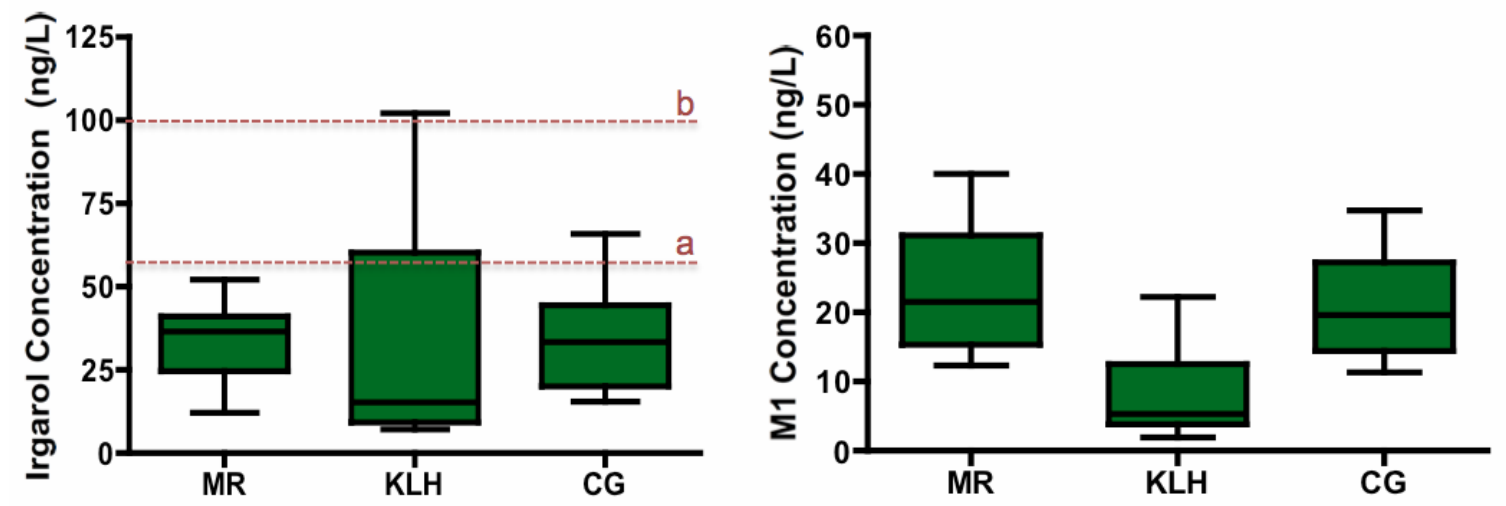

Figure 0.16 Comparison between locations, 2008. $\mathrm{a}=63 \mathrm{ng} / \mathrm{L}, \mathrm{b}=100 \mathrm{ng} / \mathrm{L}$. One-way ANOVA for Irgarol is not significant and for M1 is significant.

Seasonal differences between KLH and CG are not statistically significant for Irgarol and M1. Water concentration of Irgarol and M1 was divided into wet and dry season and analyzed by student t-test $(\mathrm{p}>0.07)$ (Figure 2.10 and 2.13).

Concentrations of Irgarol in Florida coastal waters are lower compared to concentrations reported elsewhere in the world. The resulting $90^{\text {th }}$ percentile Irgarol concentration for all South-east Florida, $184 \mathrm{ng} / \mathrm{L}$, is well above the level determined to effect corals and other small marine biota (Figure 2.14, Table 2.12). Out of the 67 samples, 26 were above the level shown to affect the net photosynthesis of intact corals. 
The $90^{\text {th }}$ percentile was analyzed by one-way ANOVA and found to be statistically significant for both Irgarol $(p=0.002)$ and M1 $(p=0.001)$.

To determine the ecological risk from Irgarol and M1 exposure in South Florida surface waters, exposure distributions were compared with the $10^{\text {th }}$ percentile toxicity (193 ng/L) calculated from several plant toxicity data (Hall et al. 2009). This value is the amount of Irgarol determined to kill $10 \%$ of all plant species exposed to Irgarol. As a whole, KLH exceeded this benchmark. Out of the 24 individual samples collected in 2007 and 2008 only one individual water sample exceeded the benchmark. KLH01 and KLH02, two sites with the least water turnover at KLH, consistently exceeded the concentration shown to affect coral (63 ng/L).

These data indicate KLH is an area of concern since it has historically been an area of elevated Irgarol in surface waters. Coconut Grove and MR surface waters were not heavily impacted by Irgarol when compared to KLH. With regard to long-term persistence of Irgarol and M1, levels in CG did not change significantly between 2006 and 2008. Levels of Irgarol at KLH were similar between 2007 and 2008.

Table 0.12 Irgarol and M1 $90^{\text {th }}$ percentiles. Irgarol and M1 were statistically significant by one-way ANOVA $(p<0.002)$

\begin{tabular}{|c|c|c|c|c|}
\hline \multirow[b]{2}{*}{ Location } & \multirow[b]{2}{*}{ Year } & \multirow[b]{2}{*}{ Observations } & \multicolumn{2}{|c|}{$\begin{array}{c}9^{\text {90 }} \text { Percentile } \\
\text { (ng/L) }\end{array}$} \\
\hline & & & Irgarol & M1 \\
\hline Coconut Grove & 2006-2008 & 24 & 76 & 34 \\
\hline Key Largo Harbor & 2004-2008 & 35 & 392 & 87 \\
\hline Miami River & 2008 & 8 & 69 & 44 \\
\hline Southeast Florida & 2004-2008 & 67 & 184 & 59 \\
\hline
\end{tabular}


The total amount of Irgarol was estimated for MR, CG and KLH in 2007 and 2008 (Table 2.13). The estimated amount of Irgarol is small and almost insignificant when compared with the content of Irgarol in a typical paint formulation $(2 \%$ of $3.8 \mathrm{~L} \sim$ 77 g) (Gardinali et al. 2004). This observation, combined with the limited exchange from the river, marina and harbor waters, and occurrence of M1, suggests that Irgarol is quickly removed from the water column by photolysis as well as water exchange. Coconut Grove had the highest estimated levels of Irgarol in the water column at $116 \mathrm{~g}$ and $164 \mathrm{~g}$ in 2007 and 2008, respectively. Key Largo Harbor (KLH01 - KLH04) contained an estimated $91 \mathrm{~g}$ and $52 \mathrm{~g}$ in 2007 and 2008 respectively. These data show seasonal differences in estimated Irgarol; levels are higher in the wet season and lower in the dry season. Interestingly, estimated M1 is higher in CG than in KLH, probably due to shallower waters in CG allowing for increased photolysis compared to KLH.

Table 0.13 Irgarol and M1 estimated in water column.

\begin{tabular}{cc|cc}
\hline \multirow{2}{*}{ Location } & \multirow{2}{*}{ Date } & \multicolumn{2}{|c}{$\begin{array}{c}\text { Estimated Amount of Herbicide }(\mathrm{g}) \\
\text { Irgarol }\end{array}$} \\
& $5 / 10 / 07$ & 116 & M1 \\
\hline \multirow{2}{*}{ Coconut Grove } & $2 / 4 / 08$ & 164 & 71 \\
\hline \multirow{2}{*}{ Key Largo Harbor } & $6 / 6 / 07$ & 91 & 22 \\
& $1 / 25 / 08$ & 52 & 12 \\
\hline Miami River & $5 / 20 / 10$ & 65 & 46 \\
\hline
\end{tabular}




\section{Distribution of Irgarol, M1 and M3 in SAVs.}

Seagrasses are a dominant component of the South Florida hydroscape occupying a position between freshwater environments and the deep ocean. Approximately 50 species of marine seagrasses exist worldwide but only six rooted vascular plants are found in Florida waters. The most prevalent species widely distributed throughout Florida estuaries are: Halodule wrightii, an early colonizer of shallow waters, Syringodium filiforme, otherwise known as manatee-grass, and Thalassia testudinum, otherwise known as turtle-grass. The South-east Florida marine environment is dominated by Thalassia (Fourqurean et al. 2001).

The inability of sediments to accumulate Irgarol and M1 above the detection limit is well documented (Chapter 2). Additionally, detection of Irgarol at concentrations shown to affect corals requires the extraction by large scale $(2 \mathrm{~L})$ liquid-liquid extraction. This process is a time consuming and manual procedure (Chapter 2 methods). Therefore, submerged aquatic vegetation are the preferable biological samples to analyze because of their ability to uptake Irgarol, allowing concentration of this substance in their leaves. One, or all, species of SAV found in CG and KLH waters are proposed to function as sentinel indicators of Irgarol and/or M1 contamination.

\subsection{Experimental}

\subsubsection{Submerged Aquatic Vegetation Sample Collection}

Submerged aquatic vegetation were collected manually by pulling them gently from the sediment to include both the roots system and the blades, sorted out immediately 
and wrapped in hexane rinsed aluminum foil to remove aromatic hydrocarbon and polychlorinated organic contamination. Immediately upon returning to the laboratory seagrasses were freeze-dried and refrigerated and stored at in darkness $<-10^{\circ} \mathrm{C}$ until ready for analysis.

\subsubsection{Surface Water Aquatic Vegetation Sample Collection}

Aquatic vegetation were found on surface waters and collected manually, sorted out immediately and wrapped in hexane rinsed aluminum foil. Immediately upon returning to the laboratory seagrasses were freeze-dried and refrigerated and stored in darkness at $<-10^{\circ} \mathrm{C}$ until ready for analysis.

\subsubsection{Segmenting SAVs}

Submerged aquatic vegetation were collected as described in Section 3.1.1. Immediately upon returning to the laboratory they were cut with solvent rinsed scissors (first with methylene chloride, then methanol, and lastly hexane) before freeze-drying. Samples were then refrigerated and stored in darkness at $<-10^{\circ} \mathrm{C}$ until ready for analysis.

\subsubsection{Submerged Aquatic Vegetation Sample Extraction}

A 2 g sample of freeze-dried vegetation was measured and extracted as described in section 2.2.2.2. 


\subsection{Results}

\subsubsection{SAV Contamination}

Bioconcentration factors were calculated with the following equation:

$$
B C F(\text { of compound })=\frac{\text { concentration in tissue }(\mathrm{ng} / \mathrm{Kg})}{\text { concentration in water }(\mathrm{ng} / \mathrm{L})}
$$

Bioconcentration factors greater than 1000 normally indicate that the SAV efficiently accumulate herbicide from the water column. All SAVs except Anadyomene had Irgarol BCFs greater than 1000. Previous research reported BCFs in Zostera marina up to 25000 in Southwest England field studies (Scarlett et al. 1999a). This value is comparable to the highest values obtained for Halodule $\left(\mathrm{BCF}_{\mathrm{AVG}}=21634\right)$ analyzed in this study. The maximum $\mathrm{BCF}\left(\mathrm{BCF}_{\mathrm{MAX}}\right)$ reported for Zostera marina was almost twice the value obtained for Syringodium $\left(\mathrm{BCF}_{\mathrm{MAX}}=11109\right)$ and Thalassia $\left(\mathrm{BCF}_{\mathrm{MAX}}=11889\right)($ Table 3.1). Irgarol and M1 were compared by two-tailed T-test to confirm statistical significance $(\mathrm{p}<0.05)$. Marine angiosperm (Thalassia, Halodule and Syringodium) and macroalgae (except Anadyomene and Udotea) BCFs were compared separately by oneway ANOVA and found to be statistically significant $(\mathrm{p}=0.0014)$ (Figure 3.1).

To determine if SAVs other macroalgae were also impacted, the macroalgae Acetabularia, Anadyomene, Caulerpa, Halimeda and Udotea were also analyzed. Average BCFs for these SAVs ranged between 258 and 7260. (Figure 3.1 and 3.2). A separate study reported $\mathrm{BCFs}$ for the macrophytes Potamogeton and Elodea at approximately 2700 and 4497, respectively (Nystrom et al. 2002). These values are comparable to the $\mathrm{BCF}$ values calculated for the macroalgae analyzed in this study. There was no statistical difference between seasonal accumulations of Irgarol (Figure 3.2). 
Additionally there was no difference between the same species of SAV sampled at CG and KLH (Figure 3.3). This agrees with the water data showing no statistical difference between CG and KLH in 2008 (Figure 2.16).

Halodule, Thalassia, Syringodium and Caulerpa were the only SAVs displaying the ability to uptake M1. Of these SAVs Halodule and Syringodium had the highest frequency for uptaking M1, while Syringodium M1 values were between $13-19 \%$ of the Irgarol value. Halodule values showed more variability, between 4 and $27 \%$ of Irgarol (Table 3.1, 3.2 and 3.3). M1 is more polar and hydrophilic than Irgarol, therefore, accumulation in SAV leaves was predicted to be less than that of Irgarol. Additionally, this compound is less toxic than Irgarol and is therefore expected to bind less efficiently to the D1 protein of the photosystem II complex.

Ninetieth percentile BCFs were calculated as described (Hall et al. 1999). For all SAVs, $90^{\text {th }}$ percentiles were calculated using the maximum BCF for each SAV at each site to add a degree of conservatism to the calculation. Submerged aquatic vegetation containing concentrations of Irgarol below the limit of detection were included in the analysis as $\mathrm{BCF}=0.0$. The Irgarol and $\mathrm{M} 190^{\text {th }}$ percentile was 10527 and 376 , respectively (Figure 3.4). When analyzing maximum values by year, the $200890^{\text {th }}$ percentile was lower, (though not significantly) than that of 2007, at 15693 and 12231 , respectively (Figure 3.5). 


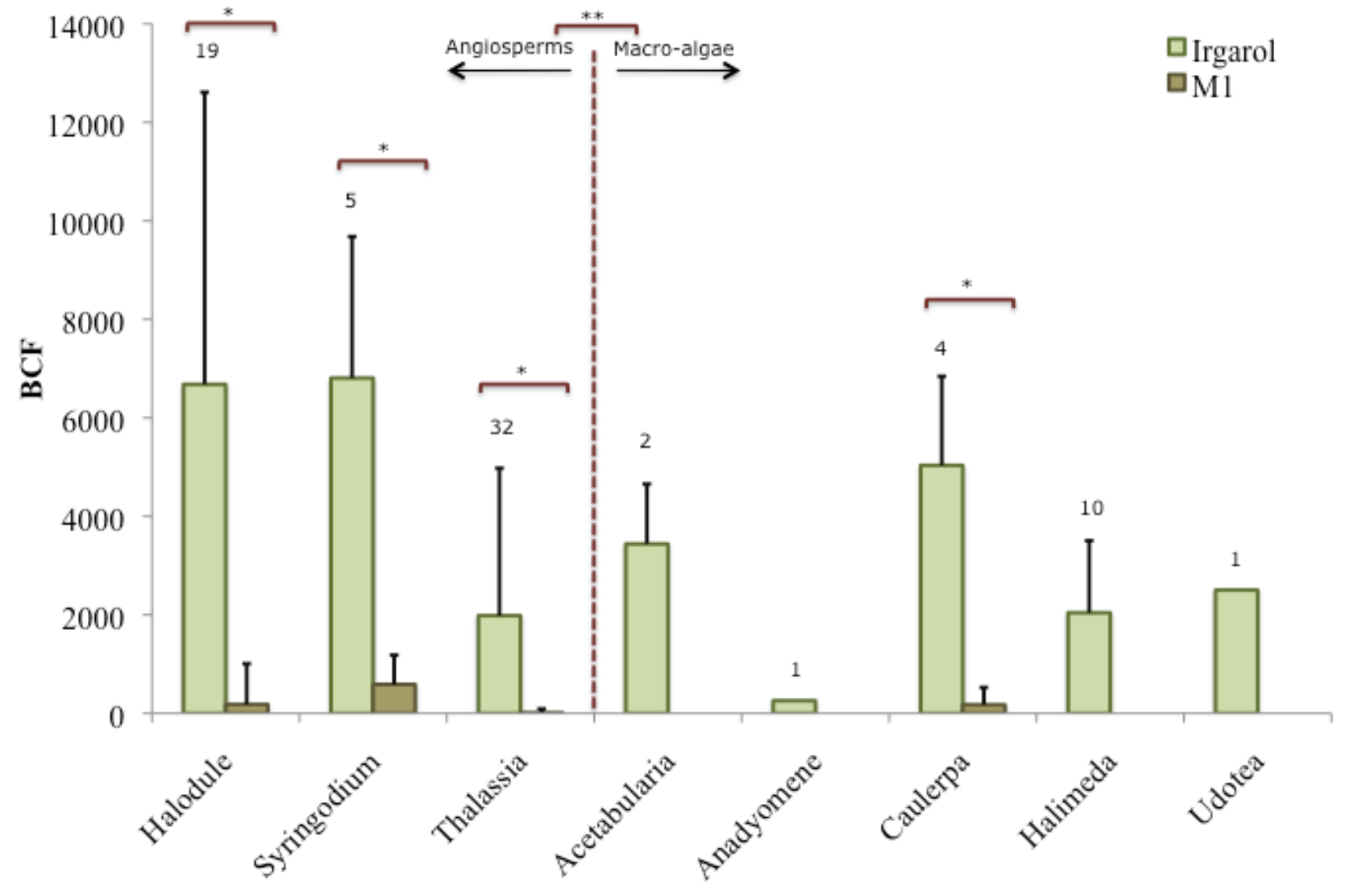

Figure 0.1 Irgarol and M1 SAV BCFs in CG and KLH, 2007 - 2008.

Number above bar indicates total number of samples. * Indicates T-test $\mathrm{p}<\mathbf{0 . 0 0 2 .}{ }^{* *} \mathrm{p}=0.13$ 


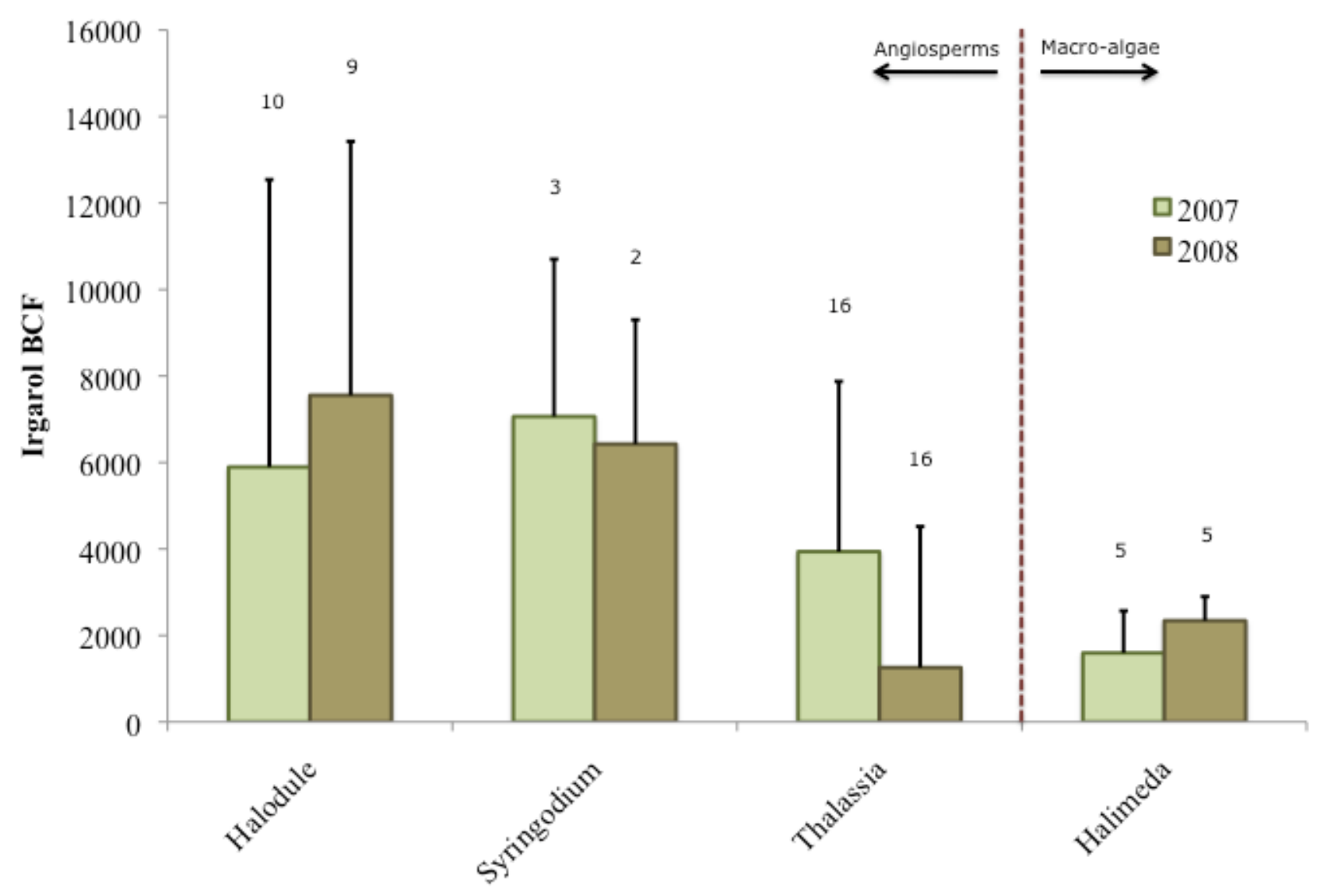

Figure 0.2 Irgarol BCFs in South-east Florida, 2007 versus 2008.

Number above bar indicates total number of samples. 


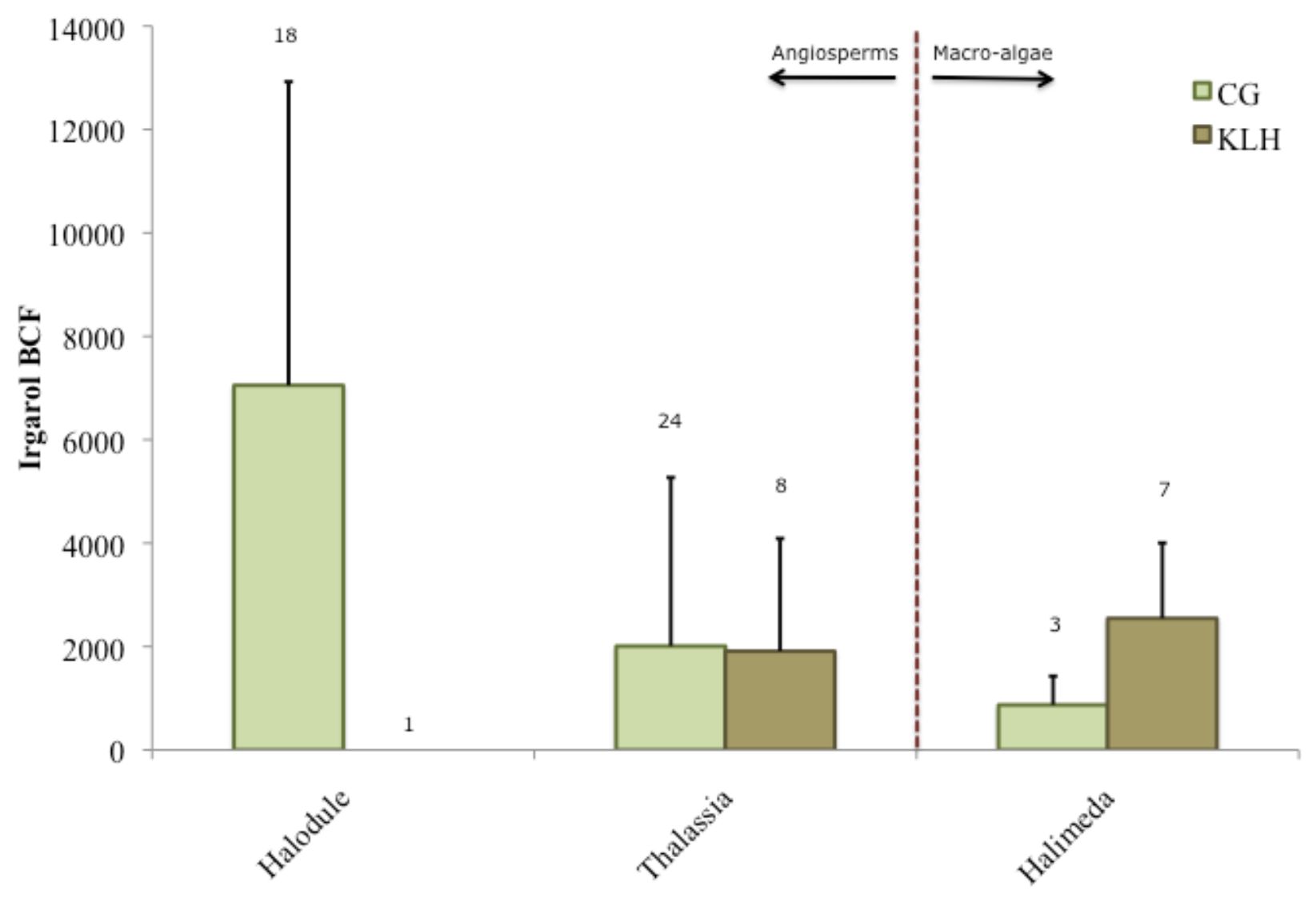

Figure 0.3 Average SAV Irgarol BCFs in CG and KLH.

Number above bar indicates total number of samples. 
A
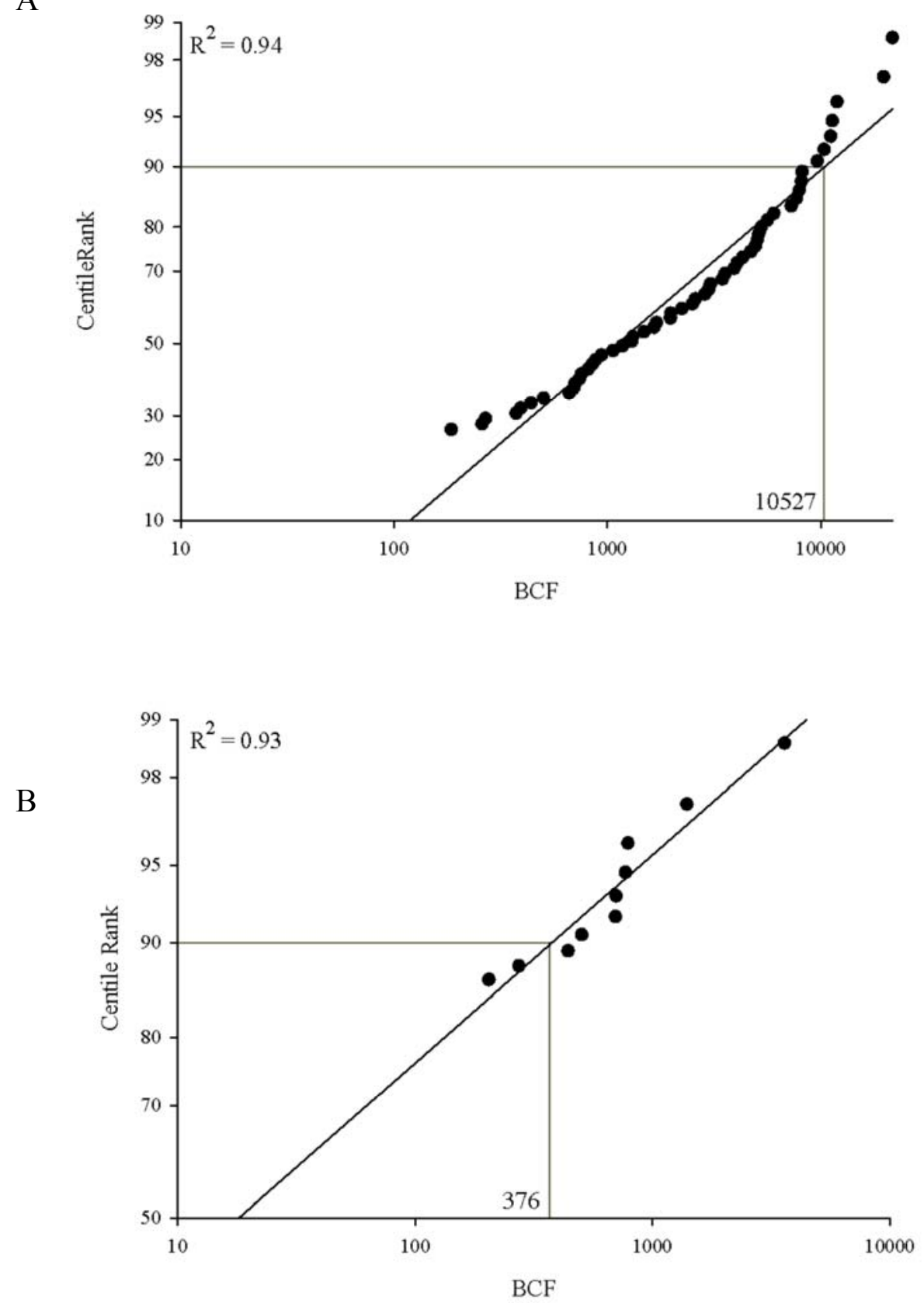

Figure 0.4 Max BCF percentile plot for herbicides.

Irgarol (A) and M1 (B) SAV BCFs from 2007 and 2008. $p=3.42 \times 10^{-11}$. 

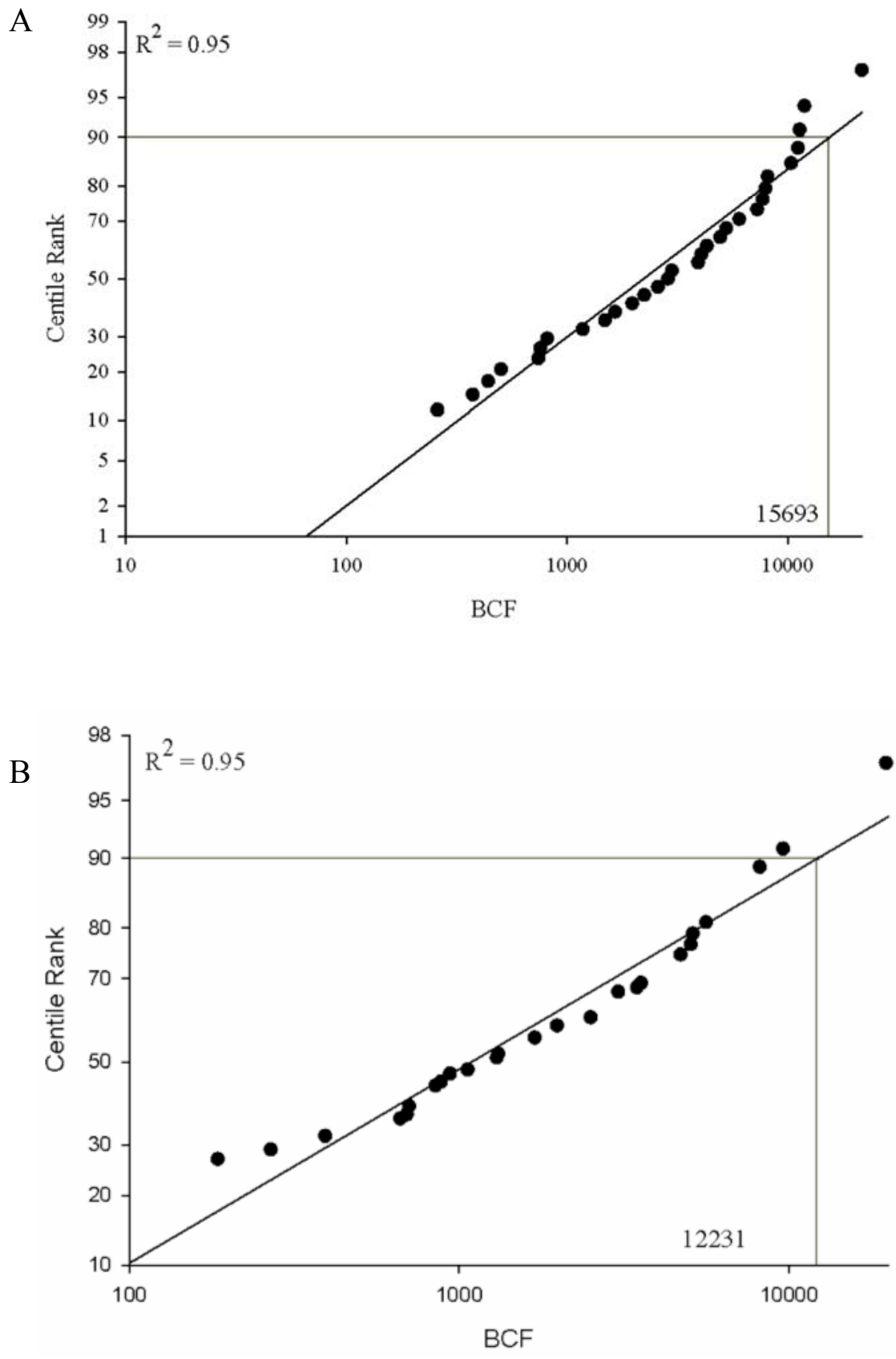

Figure 0.5 Max BCF percentile plots for 2007 and 2008. Irgarol BCFs in 2007 (A) and 2008 (B). p = 0.4. 
Table 0.1 SAV Irgarol and M1 BCFs, CG and KLH.

\begin{tabular}{|c|c|c|c|c|c|c|}
\hline \multirow{2}{*}{ SAV } & \multicolumn{6}{|c|}{ Irgarol } \\
\hline & MEAN & SD & MIN & MAX & \% Detected & $\mathbf{N}$ \\
\hline Halodule & 6681 & 5930 & N.D. & 21634 & 95 & 19 \\
\hline Syringodium & 6809 & 2872 & 4055 & 11109 & 100 & 5 \\
\hline Thalassia & 1984 & 2995 & N.D. & 11889 & 91 & 32 \\
\hline Acetabularia & 3441 & 1216 & 2581 & 4301 & 100 & 2 \\
\hline Anadyomene & 258 & & & & 100 & 1 \\
\hline Caulerpa & 5037 & 1807 & 2860 & 7260 & 100 & 4 \\
\hline Halimeda & 2044 & 1462 & 392 & 5036 & 100 & 10 \\
\hline \multirow[t]{3}{*}{ Udotea } & 2504 & & & & 100 & 1 \\
\hline & & & & M1 & & \\
\hline & MEAN & SD & MIN & MAX & \% Detected & HITS \\
\hline Halodule & 182 & 827 & 204 & 3595 & 26 & 6 \\
\hline Syringodium & 589 & 594 & 768 & 1393 & 60 & 3 \\
\hline Thalassia & 13.8 & 77.9 & N.D. & 441 & 3 & 1 \\
\hline Acetabularia & N.D. & & & & & \\
\hline Anadyomene & N.D. & & & & & \\
\hline Caulerpa & 175 & 351 & N.D. & 701 & 25 & 1 \\
\hline Halimeda & N.D. & & & & & \\
\hline Udotea & N.D. & & & & & \\
\hline \multicolumn{7}{|c|}{$\begin{array}{l}\text { N.D. = Not Detected } \\
\mathrm{N}=\text { Number of Samples } \\
\text { Hits = Number of samples above Limit of Detection } \\
\text { Min = Minimum } \\
\text { Max = Maximum }\end{array}$} \\
\hline
\end{tabular}


Table 0.2 SAV Irgarol BCFs, CG and KLH.

\begin{tabular}{|c|c|c|c|c|c|c|}
\hline \multirow{2}{*}{ SAV } & \multicolumn{6}{|c|}{ Irgarol - CG } \\
\hline & MEAN & SD & MIN & MAX & $\mathbf{N}$ & HITS \\
\hline Halodule & 7053 & 5871 & 942 & 21634 & 18 & 18 \\
\hline Syringodium & 6809 & 2872 & 4055 & 11109 & 5 & 5 \\
\hline Thalassia & 2008 & 3262 & N.D. & 11889 & 24 & 23 \\
\hline Acetabularia & 3441 & 1216 & 2581 & 4301 & 2 & 2 \\
\hline Anadyomene & 258 & & & & 1 & 1 \\
\hline Caulerpa & 5037 & 1807 & 2860 & 7260 & 4 & 4 \\
\hline Halimeda & 871 & 557 & 392 & 1481 & 3 & 3 \\
\hline \multirow[t]{3}{*}{ Udotea } & 2504 & & & & 1 & 1 \\
\hline & \multicolumn{6}{|c|}{ Irgarol - KLH } \\
\hline & MEAN & SD & MIN & MAX & $\mathbf{N}$ & HITS \\
\hline Halodule & N.D. & & & & 1 & N.D. \\
\hline Syringodium & & & & & N.D. & \\
\hline Thalassia & 1910 & 2181 & N.D. & 5608 & 8 & 6 \\
\hline Acetabularia & & & & & N.D. & \\
\hline Anadyomene & & & & & N.D. & \\
\hline Caulerpa & & & & & N.D. & \\
\hline Halimeda & 2546 & 1457 & 847 & 5036 & 7 & 7 \\
\hline Udotea & & & & & N.D. & \\
\hline \multicolumn{7}{|c|}{$\begin{array}{l}\text { N.D. = Not Detected } \\
\mathrm{N}=\text { Number of Samples } \\
\text { Hits = Number of samples above Limit of Detection } \\
\text { Min = Minimum } \\
\text { Max = Maximum }\end{array}$} \\
\hline
\end{tabular}


Table 0.3 SAV Irgarol BCF, 2007 - 2008.

\begin{tabular}{|c|c|c|c|c|c|c|}
\hline \multirow{2}{*}{ SAV } & \multicolumn{6}{|c|}{ Irgarol -May/June 2007} \\
\hline & MEAN & SD & MIN & MAX & $\mathbf{N}$ & HITS \\
\hline Halodule & 5895 & 6646 & N.D. & 21634 & 10 & 10 \\
\hline Syringodium & 7063 & 3640 & 4055 & 11109 & 3 & 3 \\
\hline Thalassia & 3938 & 3938 & N.D. & 11889 & 16 & 13 \\
\hline Acetabularia & 3441 & 1216 & 2581 & 4301 & 2 & 2 \\
\hline Anadyomene & 258 & & & & 1 & 1 \\
\hline Caulerpa & 5037 & 1807 & 2860 & 7260 & 4 & 4 \\
\hline Halimeda & 1595 & 974 & 392 & 2982 & 5 & 5 \\
\hline \multirow[t]{3}{*}{ Udotea } & & & & & N.D. & \\
\hline & \multicolumn{6}{|c|}{ Irgarol - Jan/Feb 2008} \\
\hline & MEAN & SD & MIN & MAX & $\mathbf{N}$ & HITS \\
\hline Halodule & 7555 & 5273 & 1298 & 19688 & 9 & 9 \\
\hline Syringodium & 6428 & 2454 & 4692 & 8163 & 2 & 2 \\
\hline Thalassia & 1258 & 1380 & 185 & 5608 & 16 & 16 \\
\hline Acetabularia & & & & & N.D. & \\
\hline Anadyomene & & & & & N.D. & \\
\hline Caulerpa & & & & & N.D. & \\
\hline Halimeda & 2342 & 1736 & 847 & 5036 & 5 & 5 \\
\hline Udotea & 2504 & & & & 1 & 1 \\
\hline
\end{tabular}

N.D. $=$ Not Detected

$\mathrm{N}=$ Number of Samples

Hits $=$ Number of samples above Limit of Detection

Min $=$ Minimum

Max $=$ Maximum 


\subsubsection{Surface Aquatic Vegetation Contamination}

Table 0.4 Surface vegetation compared to submerged.

\begin{tabular}{l|cccc}
\hline \multicolumn{1}{c|}{ SAV } & $\begin{array}{c}\text { Irgarol } \\
\text { (ng/g) }\end{array}$ & $\begin{array}{c}\text { Surface } \\
\text { Irgarol BCF }\end{array}$ & $\begin{array}{c}\text { Mean Submerged } \\
\text { Irgarol BCF }\end{array}$ & $\begin{array}{c}\text { \% BCF } \\
\text { (Submerged/Surface) }\end{array}$ \\
\hline Halodule & 19.4 & 817 & 6681 & 8.18 \\
Syringodium & 4.93 & 207 & 6809 & 32.9 \\
Thalassia & 5.92 & 249 & 1984 & 7.97 \\
\hline
\end{tabular}

Syringodium, Halodule and Thalassia leaves were collected from surface water southwest of CG04. They appeared to have been freshly severed from their root systems by a propeller. The origin of these seagrasses and time detached from their root system is not known. Comparing surface SAV BCFs to the average BCF of submerged counterparts shows that all surface seagrasses had lower BCFs. The submerged Syringodium BCF was greater than its surface counterpart by a factor of 33. Submerged Halodule and Thalassia BCFs were greater than floating species by a factor of approximately 8 (Table 3.4 ). These data confirm that intact submerged vegetation is the preferable state for monitoring Irgarol contamination. Replicates were not available for this analysis because of limited sample availability during this collection.

\subsection{Conclusion}

Submerged aquatic vegetation show great variability in their ability to uptake Irgarol and M1 both intra- and inter-species. Syringodium and Halodule had a higher average Irgarol BCF than the macroalgae sampled. Thalassia had a lower BCF $\mathrm{AVG}$ (1984) than all macroalgae. The $\mathrm{BCF}_{\mathrm{AVG}}$ values obtained for Halodule, 6681, were lower than those calculated by Scarlett et al. (25000), but the max value recorded here for this 
species (21634) is comparable. Additionally, there was no statistical difference between seasonal accumulation of Irgarol (Figure 3.2) and between the same species of SAV sampled at CG and KLH (Figure 3.3). This data agrees with the availability of Irgarol in the water column (Chapter 2).

Consistent with these observations, Syringodium and Halodule average M1 BCFs were also highest, 589 and 182 respectively, while Thalassia was lower at 13.8. Caulerpa was the only macroalgae to display $\mathrm{M} 1$ uptake abilities with a $\mathrm{BCF}_{\mathrm{AVG}}$ of 175 . This macroalgae also had the highest Irgarol $\mathrm{BCF}_{\mathrm{AVG}}$ of the five macroalgae sampled in this study at 5037 (Figure 3.1). The range of Irgarol bioaccumulated by macroalgae determined in this study is comparable to other macroalgae species bioaccumulation studies (Table 1.2). The ability of SAVs to bioaccumulate Irgarol corresponds to their ability to uptake M1, between $4-27 \%$ of the Average Irgarol value.

The occurrence of twin species of the three seagrasses Thalassia, Syringodium and Halodule in Caribbean/West Atlantic and Indo-Pacific coastal waters makes them useful for environmental monitoring throughout these waters. Therefore these three SAVs may function as sentinel indicators of Irgarol contamination at locations other than South-east Florida. Further investigation is required to determine the long-term acute and chronic effects Irgarol has on submerged vegetation such as: promotion and/or prevention of epiphytic growth, photo inhibition, photodamage, effects on breeding, and inhibition of leaf growth rates. 


\section{Ability of SAV to Uptake and Depurate Irgarol}

\subsection{Experimental}

\subsubsection{SAV segmentation}

Submerged aquatic vegetation cut with solvent rinsed scissors (as shown in Figure 4.2) into four segments. Each portion of the SAV was then isolated and analyzed separately for Irgarol and M1 as described in Chapter 2.

\subsubsection{Transplant of Thalassia and Halodule}

Six-inch PVC pipes were cut a foot high and beveled on the bottom to facilitate placement into the sediment. Pink or green neon string was attached at the top to aid in locating the samples from above the surface water and each pipe was numbered for identification (Figure 4.1). The pipes were pushed into the sediment to a depth of $20 \mathrm{~cm}$, necessary to completely surround a target SAV plug and to cut through the root system to produce a transportable plug. The SAV plugs were removed and stored in a cooler with native water during transport to the transplantation site. Transplants were embedded into the sea floor 10 meters away from the controls. Sample collections of two plugs per site were made approximately every week and analyzed as described above. Two controls were available: a PVC unit left at the transplant sites and an unmodified submerged SAV (referred to as "Free"). Data obtained from these experiments were not included in other analysis. 


\subsubsection{Sample collection}

Submerged aquatic vegetation were collected manually by pulling the plug (described in 4.1.1) gently from the sediment to include both the roots system and the blades. Excess sediment was gently washed from the roots before storing the seagrasses in hexane rinsed aluminum foil. Samples were then immediately freeze-dried, refrigerated and stored in darkness at $<-10^{\circ} \mathrm{C}$ until ready for analysis.

\subsubsection{Sample Extraction}

Herbicides were extracted using the method described in Section 3.1. 


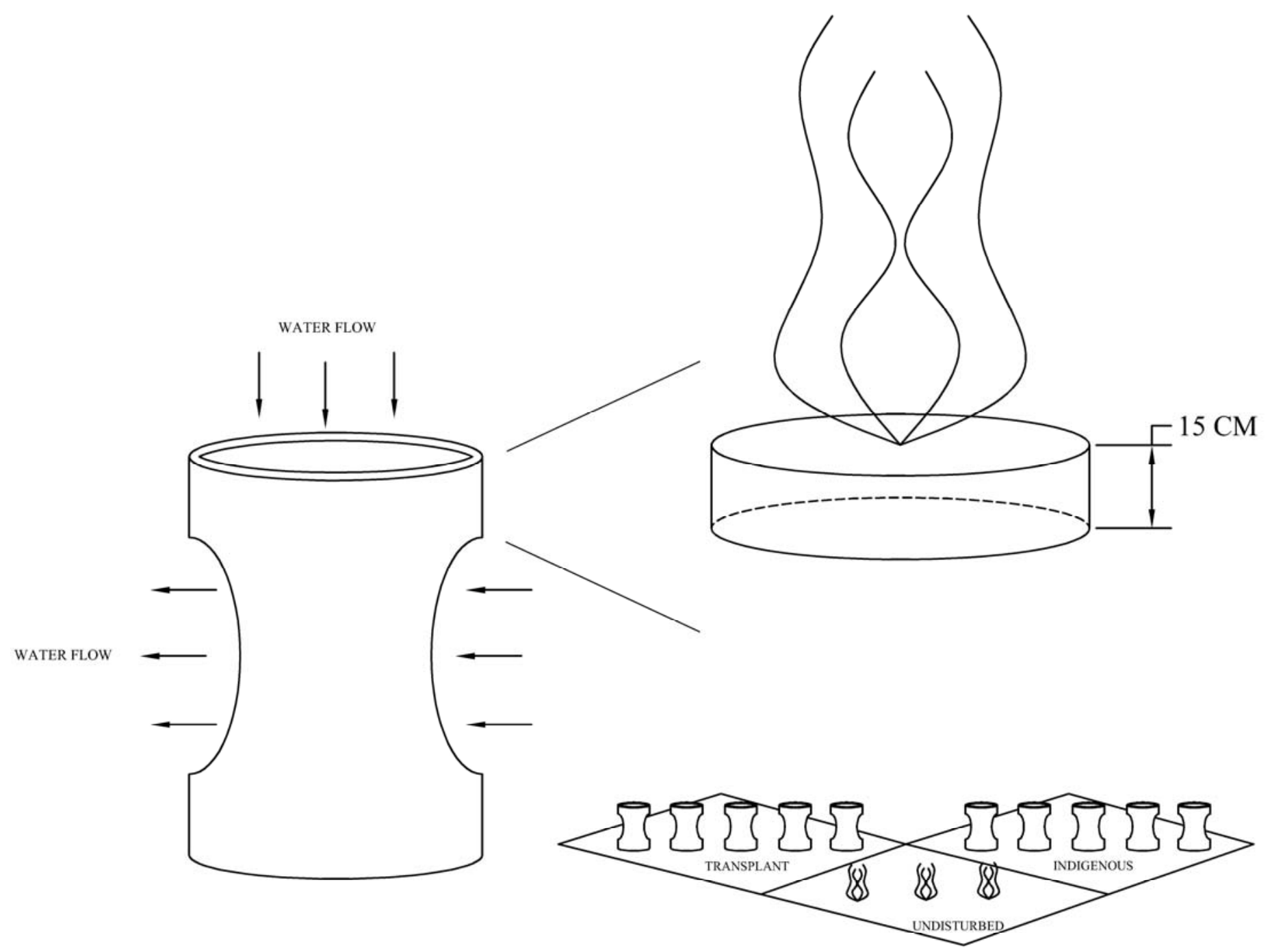

Figure 0.1 Schematic of SAV transplant device. 


\subsection{Results}

\subsubsection{Distribution in Aquatic Vegetation Tissue}

Different portions of the SAVs Halodule and Thalassia were analyzed to determine if differential uptake of Irgarol by leaves and roots occurred in these species. Two SAV species, Halodule and Thalassia, were chosen to evaluate Irgarol segregation within the plant. The seagrasses were sampled carefully to collect both the full leaves and the rhizome-root system. These data indicated that Halodule contained higher levels of Irgarol than Thalassia (Figure 4.1), and also showed that the two plant species bioaccumulate Irgarol throughout their tissues in different patterns (Table 4.1, Figure 4.2). Data represents single values because of limited sample availability.

The root system was least important for accumulation of Irgarol explained by the lack of detection to extremely low levels of Irgarol present in the sediment. Halodule contained no detectable Irgarol in its rhizome-roots while Thalassia roots had a low BCF of 126. Halodule's meristem had a high BCF of 7082 and a leaf tip BCF of 5795, approximately 7 and 6 times greater than Thalassia's, respectively.

Table 0.1 BCFs of SAV segments.

\begin{tabular}{l|cc|c|c|c|c|cc}
\hline \multirow{2}{*}{ Floating SAV } & \multicolumn{2}{|c|}{ leaf tip } & \multicolumn{2}{c|}{ midleaf } & \multicolumn{2}{c|}{ meristem } & \multicolumn{2}{c}{ roots } \\
\cline { 2 - 9 } & ng/g & BCF & ng/g & BCF & ng/g & BCF & ng/g & BCF \\
\hline Halodule & 293 & 5795 & 285 & 5149 & 370 & 7082 & N.D. & 0 \\
Thalassia & 48.4 & 957 & 176 & 3178 & 59.3 & 1136 & 6.39 & 126 \\
\hline
\end{tabular}

Several investigations have shown photosynthesis is not constant along a seagrass leaf (Durako et al. 2002; Enriquez et al. 2002; Mazzella et al. 1986) and this may 
possibly affect Irgarol bioaccumulation as a result of altered levels of the D1 protein. Apical sections are shown have the ability to reduce chlorophyll content in response to higher photon flux density or chronic photoinhibition, such as from Irgarol binding (See: Section 1.2.1). Additionally, the tips of the leaves tend to have a greater epiphyte load affecting photosynthetic efficiency (Enriquez et al. 2002) by causing permanent cell damage where tightly bound and a subsequent decrease in chlorophyll (Lam et al. 2009). Encrusting calcerous epiphytes may also compete for Irgarol from the water column and reduce its accumulation in the leaf tip. Together this could account for the reduced levels of Irgarol within Thalassia leaf tips found here (Figure 4.3).

The mid-leaf has higher has been shown to contain higher chlorophyll because of photoacclimation caused by canopy shading and less epiphytic load compared to the leaf tip possibly contributing to higher Irgarol bioaccumulation.

Seagrass leaves grow from the basal meristem where the leaf tip is the oldest tissue and the basal meristem is the youngest, containing the least chlorophyll (Enriquez et al. 2002). The meristem also has the leaf sheath adding to total tissue weight but containing no photosynthetic tissue, which could cause an apparent decreased bioaccumulation. 
Halodule

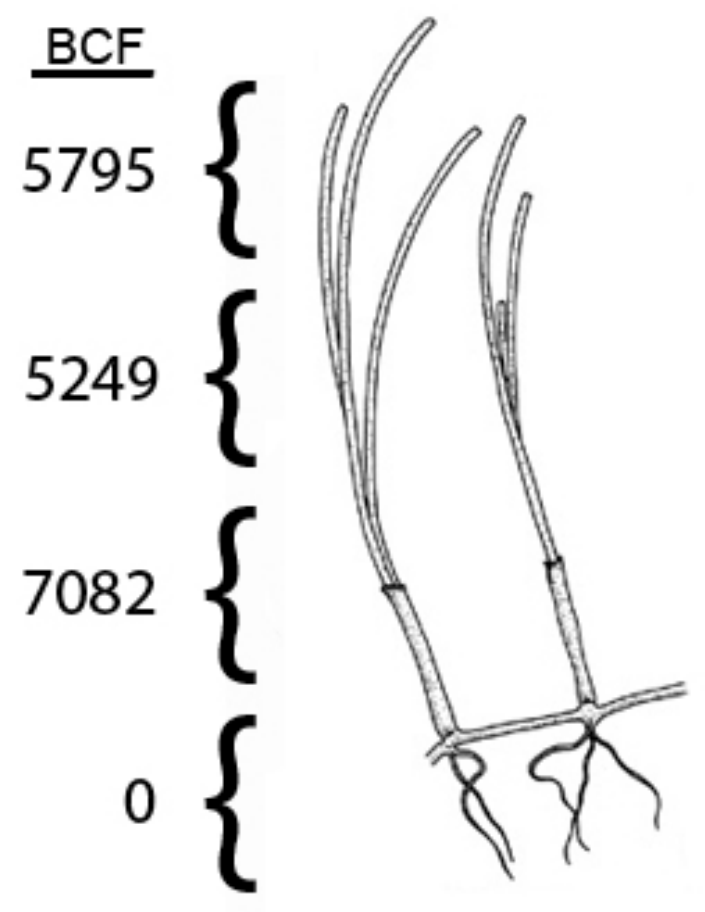

Thalassia

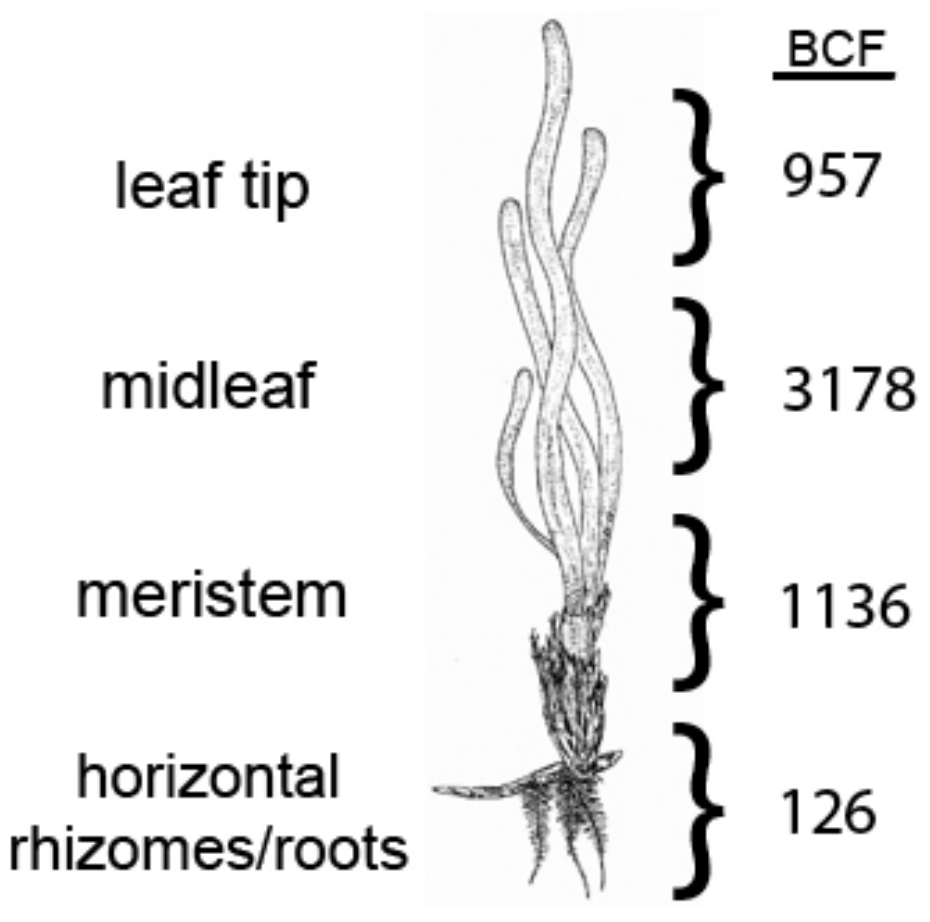

Figure 0.2 Distribution of Irgarol in Halodule and Thalassia. 


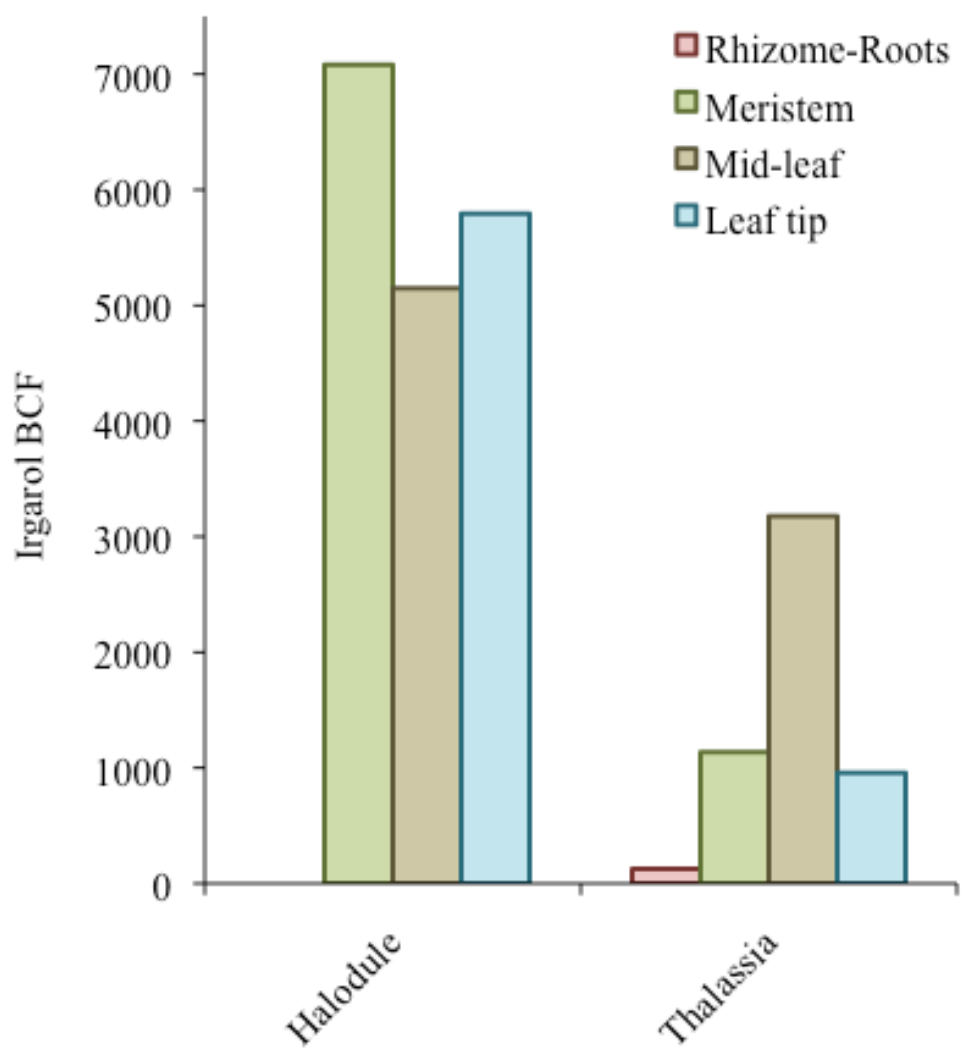

Figure 0.3 Distribution of Irgarol throughout Halodule and Thalassia. 


\subsubsection{Thalassia and Halodule Transplant}

A summer transplant was performed for Halodule and Thalassia to determine their depuration and uptake rates, respectively. Halodule was transplanted from a contaminated site, CG04, to an isolated and uncontaminated site, CK. Unfortunately for this study, Halodule was not available at $\mathrm{CK}$ and Thalassia was not available to CG04. Therefore, uptake and depuration kinetics were determined for Thalassia and Halodule, respectively.

The Irgarol concentration in surface water throughout this transplant study was consistent at $47.1 \pm 8.1 \mathrm{ng} / \mathrm{L}$ and $0 \mathrm{ng} / \mathrm{L}$ at CG04 and CK, respectively (Table 4.3).

The transplant BCF for Halodule was fitted to an exponential curve $\left(\mathrm{R}^{2}=0.95\right)$ yielding a decay constant of 0.10 and a half-life of 6.93 days (Figure 4.4). The half-life was calculated using the following equation:

$$
t_{1 / 2}=\frac{\ln (2)}{\lambda} \quad \text { ( Eq. 2) }
$$

where $\lambda$ is the decay constant obtained by fitting the data to a first-order exponential decay curve.

Thalassia was transplanted from CK to CG04 with an initial Irgarol tissue level of $0 \mathrm{ng} / \mathrm{g}$. The transplant data was fitted to an exponential curve $\left(\mathrm{R}^{2}=0.87\right)$ yielding an uptake rate of 0.11 (Figure 4.4).

Previous uptake studies on Zostera marina showed a linear relationship between leaf tissue concentration and water concentration (Scarlett et al. 1999a). If the fourth collection date $(\mathrm{T}=32$ days $)$ is considered an outlier and excluded from the data fitting, a 
linear uptake with an $\mathrm{R}^{2}$ of 0.97 is achieved indicating that the uptake of Irgarol by Thalassia might also be linear, rather than exponential, in nature. The outlier point can be explained by photobleaching or variability within the specie for uptake (Figure 4.4).

Halodule displays an exponential depuration of Irgarol and is able to nearly eliminate Irgarol within 3 weeks. The last three collection dates resulted in similar Irgarol BCFs, albeit very low, from 257 to 109 . Alternatively, the data can be interpreted to a rapid linear depuration of Irgarol followed by a steady state level. 

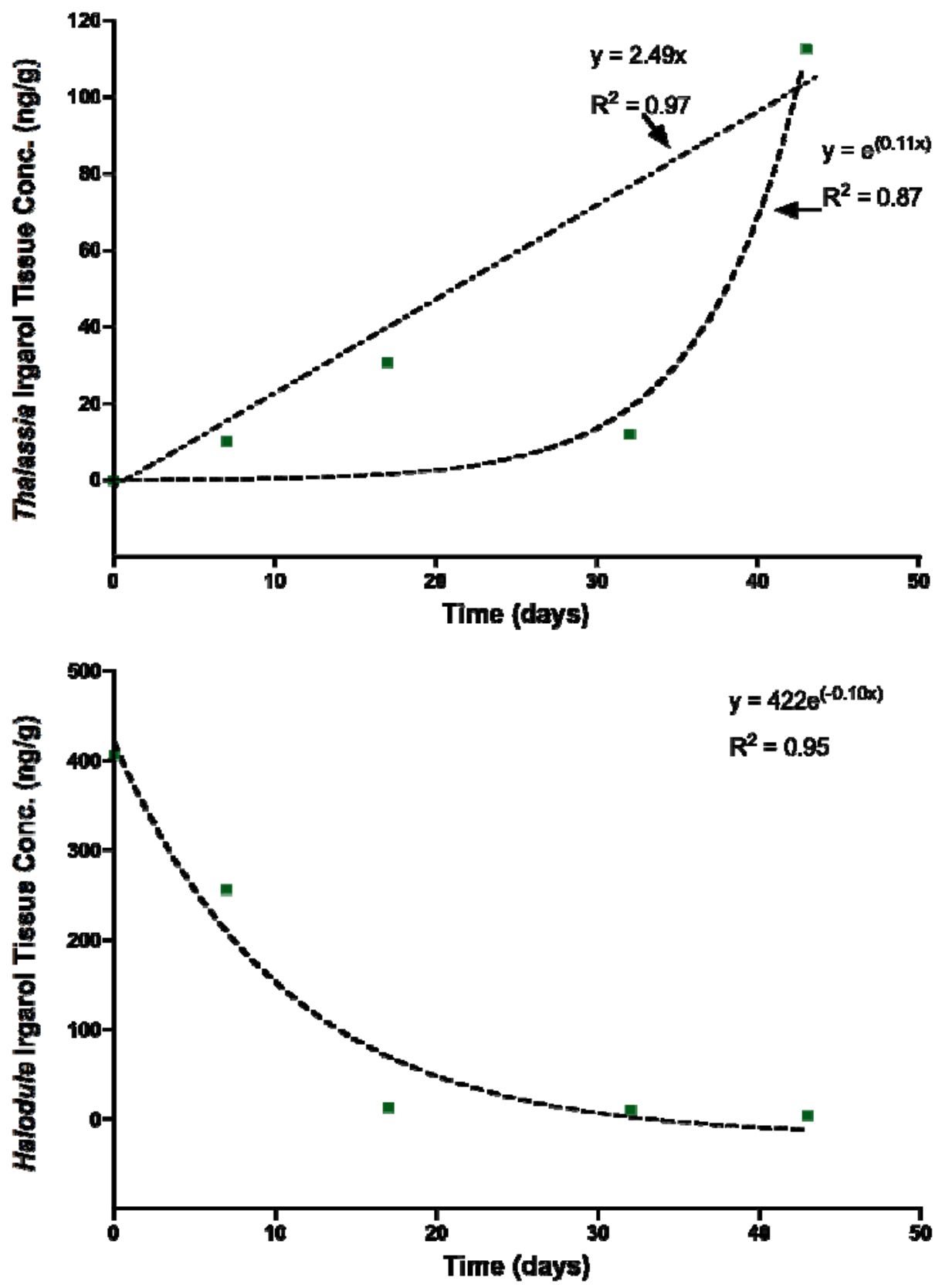

Figure 0.4 Uptake and depuration of Irgarol by Halodule and Thalassia. 
Table 0.2 Irgarol in SAVs, transplant study.

\begin{tabular}{|c|c|c|c|c|c|c|}
\hline \multicolumn{2}{|c|}{ Transplant } & \multicolumn{5}{|c|}{ Free BCF - Irgarol } \\
\hline Location & SAV & $\mathbf{T}=\mathbf{0}$ & $T=7$ & $\mathbf{T}=\mathbf{1 7}$ & $\mathbf{T}=32$ & $\mathbf{T}=43$ \\
\hline $\mathrm{CK}$ & Thalassia & N.D. & N.D. & N.D. & N.D. & N.D. \\
\hline CG04 & Thalassia & 520 & 347 & 880 & N.S. & N.S. \\
\hline CG04 & Halodule & 8037 & 19688 & 9092 & N.S. & 5232 \\
\hline \multicolumn{7}{|c|}{ Control BCF - Irgarol } \\
\hline $\mathrm{CK}$ & Thalassia & & N.D. & N.D. & N.D. & N.D. \\
\hline CG04 & Halodule & & 24178 & 3619 & 3061 & 4472 \\
\hline \multicolumn{7}{|c|}{ Transplant BCF - Irgarol } \\
\hline $\mathrm{CK}$ to $\mathrm{CG04}$ & Thalassia & & 185 & 591 & 299 & 3101 \\
\hline CG04 to CK & Halodule & & 4629 & 257 & 244 & 109 \\
\hline
\end{tabular}

$\mathrm{T}=$ collection day after transplant $(\mathrm{T}=0)$

Table 0.3 Irgarol in waters, transplant study.

\begin{tabular}{|c|c|c|c|c|c|c|c|}
\hline \multicolumn{8}{|c|}{ Water Concentrations - Irgarol (ng/L) } \\
\hline Location & $\mathrm{T}=0$ & $\mathrm{~T}=7$ & $\mathrm{~T}=17$ & $\mathrm{~T}=32$ & $\mathrm{~T}=43$ & Mean & STD \\
\hline CK & N.D. & N.D. & N.D. & N.D. & N.D. & & \\
\hline CG04 & 50.6 & 55.4 & 52.2 & 40.9 & 36.3 & 47 & 8.1 \\
\hline \multicolumn{8}{|c|}{ Water Concentrations - Atrazine (ng/L) } \\
\hline CK & 8.8 & 9.1 & 7.9 & N.D. & N.D. & & \\
\hline CG04 & 7.9 & 9.1 & 8.4 & N.D. & N.D. & & \\
\hline \multicolumn{8}{|c|}{ Water Concentrations - M1 (ng/L) } \\
\hline CK & N.D. & N.D. & N.D. & N.D. & N.D. & & \\
\hline CG04 & 33.5 & 40.8 & 31.9 & N.D. & N.D. & & \\
\hline
\end{tabular}


4.2.3. Estimating total Irgarol accumulated in SAV biomass, Biscayne Bay

The mean annual near shore aboveground biomass for seagrasses in Biscayne Bay for 2001 was calculated previously (Lirman et al. 2003) simulated under different scenarios. The values shown in Table 4.5 refer to the mean Biomass calculated using the original seagrass model (Fong et al. 1994) in oligotrophic conditions. Using the following equation the total amount of Irgarol accumulated in the three most common seagrass species found in Biscayne Bay were calculated.

$$
\frac{n g(\text { Irgarol })}{m^{2}}=\frac{g(\text { Wet Weight })}{m^{2}} \times \frac{g(\text { Dry Weight })}{g(\text { Wet Weight })} \times \frac{n g(\text { Irgarol })}{g(\text { Dry Weight })}
$$

Dry weights were calculated from SAVs collected during the study and in Biscayne Bay and averaged (Table 4.4). Two models were available: Interactive and single-species. The interactive model assumes mixed species SAV beds and the singlespecies model assumes one species only seagrass beds.

Table 0.4 Percent dry weight of seagrasses.

\begin{tabular}{|c|c|c|c|}
\cline { 2 - 4 } \multicolumn{1}{c|}{} & $\begin{array}{l}\text { Thalassia } \\
\text { testudinum }\end{array}$ & $\begin{array}{l}\text { Syringodium } \\
\text { filiforme }\end{array}$ & $\begin{array}{l}\text { Halodule } \\
\text { wrightii }\end{array}$ \\
\hline & 18.46 & 25.18 & 14.82 \\
& 18.43 & 26.55 & 17.49 \\
& 21.37 & 27.54 & 15.95 \\
\% Dry weight & 19.03 & 17.65 & 18.96 \\
(Dry/Wet Weight*100) & 18.02 & & 19.96 \\
& 24.55 & & 16.87 \\
& 21.20 & & 14.43 \\
& & & 14.62 \\
\hline Average & 20.15 & 24.23 & 16.64 \\
Standard Deviation & 2.37 & 4.49 & 2.07 \\
\hline
\end{tabular}


Table 0.5 Estimation of Irgarol in SAV biomass.

\begin{tabular}{|c|c|c|c|c|c|c|}
\hline & \multicolumn{2}{|c|}{ Thalassia testudinum } & \multicolumn{2}{|c|}{ Syringodium filiforme } & \multicolumn{2}{|c|}{ Halodule wrightii } \\
\hline Model & Interactive & $\begin{array}{l}\text { Single- } \\
\text { Species }\end{array}$ & Interactive & Single-Species & Interactive & $\begin{array}{l}\text { Single- } \\
\text { Species }\end{array}$ \\
\hline $\begin{array}{l}\text { Mean Biomass } \\
\left(\mathrm{g} \mathrm{WW} / \mathrm{m}^{2}\right)\end{array}$ & 15 & 15 & 138 & 143 & 14 & 32 \\
\hline Mean Dry/Wet weight & 0.20 & 0.20 & 0.24 & 0.24 & 0.17 & 0.17 \\
\hline Mean Irgarol (ng/g DW) & 76 & 76 & 192 & 192 & 314 & 314 \\
\hline Estimated Irgarol $\left(\mathrm{ng} / \mathrm{m}^{2}\right)$ & 230 & 230 & 6420 & 6652 & 731 & 1672 \\
\hline
\end{tabular}




\subsubsection{Estimating percent Irgarol accumulated from the environment}

The percent of Irgarol bioaccumulated from the water column was estimated using estimations from Table 2.4 (Section 4.2.4) and the following equation:

$$
\frac{\frac{n g(\text { Estim. Irgarol in SAV })}{m^{2}(\text { SAV cov erage })} \times m^{2}}{g(\text { Irgarol in water column })} \times 100=\% \text { Irgarol bioaccumulated }
$$

Percent uptake of Irgarol from the water column was highest for Syringodium, approximately $32 \%$ in CG and $1.15 \%$ in KLH, and lowest for Thalassia, less than $1 \%$ in CG and approximately 1.15 in KLH (Table 4.6). The single-species Syringodium and Thalassia meadows are predicted to bioaccummulate slightly more Irgarol from the water column than the mixed-species stands, thought the difference is slight and probably not significant. 
Table 0.6 Estimation of percent Irgarol accumulated.

\begin{tabular}{|c|c|c|c|c|c|c|c|}
\hline & \multicolumn{2}{|c|}{ Thalassia testudinum } & \multicolumn{2}{|c|}{ Syringodium filiforme } & \multicolumn{2}{|c|}{ Halodule wrightii } \\
\hline & & Interactive & $\begin{array}{l}\text { Single- } \\
\text { Species }\end{array}$ & Interactive & Single-Species & Interactive & $\begin{array}{l}\text { Single- } \\
\text { Species }\end{array}$ \\
\hline \multirow{4}{*}{ 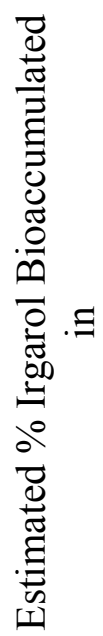 } & CG (2007) & 0.31 & 0.31 & 8.76 & 9.08 & 1.00 & 2.28 \\
\hline & CG (2008) & 0.22 & 0.22 & 6.15 & 6.37 & 0.70 & 1.60 \\
\hline & KLH (2007) & 0.94 & 0.94 & 26.3 & 27.2 & 2.99 & 6.84 \\
\hline & KLH (2008) & 1.35 & 1.35 & 37.6 & 38.9 & 4.28 & 9.78 \\
\hline
\end{tabular}




\subsection{Conclusions}

Halodule and Thalassia display different patterns of Irgarol accumulation. While most of Irgarol root biomass is belowground, its roots were not principal in storing Irgarol. Halodule had measurable concentration of Irgarol in its roots, either because of uptake or directed storage of Irgarol by the roots. The leaves were the primary plant organ able to take up Irgarol. Interestingly, Halodule and Thalassia accumulate Irgarol differently. The leaf base and tips of Halodule accumulate Irgarol more than the mid-leaf. The opposite is the case for Thalassia. The mid-leaf of Thalassia accumulates more Irgarol than any other portion of the plant. The preferential Irgarol accumulation in certain parts of the plant could be the result of varied chlorophyll content throughout the leaf. Uptake through the roots probably occurs from the sediment and so depends on the amount of Irgarol available in the sediment. The roots do not contain photosynthetic organelles, therefore bioaccumulation of Irgarol by Thalassia roots is probably an effect of the $\mathrm{K}_{\mathrm{OW}}$ and is not an effect of D1 binding. The Thalassia root Irgarol BCF of 126 lies within the range of Irgarol uptake predicted by the $\mathrm{K}_{\mathrm{Ow}}$ (Table 1.1) (Ranke et al. 2000).

Differential Irgarol accumulation throughout the leaves maybe accounted for by a variety of factors such as: seasons, leaf growth rates, water depth, epiphytic growth and plant density. Lipid content does not seem to be a factor for variability in accumulation. A study investigating lipid content between Thalassia, Halodule, and Syringodium on the western coast of Florida found that lipid composition did not differ significantly between species (Ames et al. 2007). Further research is necessary to determine which portion of candidate SAVs accumulate Irgarol most and the factors that affect this accumulation. 
A transplant between an impacted site in $\mathrm{CG}(\mathrm{CG} 04)$ and a pristine site off of $\mathrm{CK}$ demonstrated the ability of Thalassia to quickly uptake Irgarol within a week $(\mathrm{BCF}=$ $185)$ and after 43 days exposure to Irgarol $(\mathrm{BCF}=3101)$. A repeat study for a longer time period should be performed to conclude if the uptake kinetics of Irgarol by Thalassia are linear or exponential and the precise time it takes tissue levels to plateau. Depuration of Irgarol by Halodule seems to be exponential $\left(\mathrm{R}^{2}=0.95\right)$. After 43 days there were still measureable amounts of Irgarol in the plant leaves $(3.96 \mathrm{ng} / \mathrm{g})$ above the MDL.

These data show the three most commonly available seagrasses in South-Florida are all capable of bioaccumulating Irgarol. Using estimated aboveground biomass, percent dry-weight and averaged SAV Irgarol concentrations, total Irgarol sequestered in individual seagrass species was estimated. Values were comparable between interactive and single-species models within species but varied greatly between species. Total Irgarol estimated to be found in Thalassia, Syringodium and Halodule located in Coconut Grove was approximately 230, 6536 and $1201 \mathrm{ng} / \mathrm{m}^{2}$, respectively. These data show all three SAVs may serve as environmental sentinels, both measuring and cleaning up toxic substances in marinas, harbors and other contaminated marine waters. Of these three, Syringodium is the best candidate species to serve as a sentinel indicator of Irgarol contamination. 


\section{Conclusions}

Occurrence of Irgarol is a worldwide phenomenon. However, the majority of locations sampled in South-east Florida did not seem heavily impacted compared to Severn River, MD and Côte Azure, France. Of the three locations sampled chronically exposed to Irgarol, KLH was the most impacted containing Irgarol concentrations between $5.70 \mathrm{ng} / \mathrm{L}-241 \mathrm{ng} / \mathrm{L}$ in 2007 and $7.04 \mathrm{ng} / \mathrm{L}-102 \mathrm{ng} / \mathrm{L}$ in 2008. The highest levels of Irgarol were found at KLH01, where water turnover was lowest. Concentrations in surface water decreased with increasing water turnover (Figure 2.17). Sediments did not accumulate in sediments, consistent with previous studies (Gardinali et al. 2004; Maxey 2006).

Dinner Key Marina, located within CG, has expanded its capacity by opening mooring facilities in 2009. This increased capacity for long-term wet craft storage and the popularity of this storage/loading site increases the likelihood Irgarol and M1 water concentrations significantly increasing. Conversely, KLH is composed mostly of private docks, thus limiting the capacity of the harbor for marine crafts. Concentrations of Irgarol in $\mathrm{KLH}$ are not predicted to increase significantly.

When the $90^{\text {th }}$ percentile concentration exceeds the plant $10^{\text {th }}$ percentile plant toxicity level, $90 \%$ of the plant species exposed to Irgarol are expected to be negatively affected. One sample from KLH in 2007 , and none in 2008 , was above the $90^{\text {th }}$ percentile toxicity benchmark. Using the data from the 67 water samples collected throughout South-east Florida between 2004 - 2008, the calculated $90^{\text {th }}$ percentile concentration in surface waters was found to be $184 \mathrm{ng} / \mathrm{L}$ with almost $39 \%$ of the samples above the 
LOEC shown to affect the carbon uptake of coral systems $(63 \mathrm{ng} / \mathrm{L})$. There was no significant seasonal or yearly difference in Irgarol exposure between 2007 and 2008.

This study is the first report of M1 bioaccumulation in SAVs. Only Halodule, Syringodium, Thalassia, and Caulerpa are able to bioaccumulate M1. Halodule displayed quick depuration kinetics, is able to bioaccumulate M1 and has one of the highest $\mathrm{BCF}$ values in South-east Florida. Among the seagrasses, Thalassia had the lowest BCF values. The macroalgae are more consistent reporters of Irgarol contamination but their $\mathrm{BCF}$ values are lower than the average $\mathrm{BCF}$ of the marine angiosperms sampled here. Of the macroalgae Anadyomene has the least ability to bioaccumulate Irgarol.

Thalassia is the climax species in shallow waters while Syringodium and Halodule represent pioneer species. These seagrasses were found at different areas within marinas and harbors. The more chronically disturbed areas would be composed of single or mixed-specie stands of Syringodium and Halodule while the less disturbed areas would be expected to have single or mixed-specie stands of Thalassia. Data in Table 4.4 and 4.5 show Syringodium is the best candidate species to serve as an indicator of Irgarol contamination. Additionally, Thalassia and Halodule may also serve as indicators. These data show all three SAVs may be used to measure Irgarol from the water column in marinas, harbors and other contaminated marine waters.

Manual SPE method has been historically utilized for the extraction of herbicides from sediment and seagrasses. This method requires constant attention and the use of vacuum results in difficulty standardizing sample analysis. An automated SPE method was developed using Oasis HLB cartridges to facilitate and standardize the extraction of 
herbicides Irgarol and M1. The Automated method for SPE is and improvement upon the manual method as indicated by the \% R.S.D. (Table 2.4) Additionally, methanol was the best Irgarol and M1 eluting solvent (Table 2.5).

Future work in this field should concentrate on continual monitoring of CG and $\mathrm{KLH}$, as well as MR surface waters for Irgarol contamination to ensure levels do not exceed the $10^{\text {th }}$ percentile plant toxicity. Additionally, MR dissolved oxygen should be monitored to determine if the already low value of $2.38 \pm 0.59$ decreases further. Another, more extensive, transplant study should be performed to confirm the uptake and depuration constants (0.10 and 0.11 , respectively) reported here. Lastly, SAV leaves should be further studied for differential uptake of Irgarol from the water column. It is important to identify the portion of the leaf in each SAV that bioaccumulates the most Irgarol. The portion with the highest Irgarol bioaccumulation should be analyzed to increase likelihood of exceeding the limit of detection during analysis of SAVs sampled from Irgarol-sensitive environments (such as near coral reefs) where water concentrations are very low. The focus of future SAV studies should focus on the marine angiosperms with the highest average BCF, specifically Syringodium and Halodule. 


\section{REFERENCES}

Aguera, A., L. Piedra, M. D. Hernando and A. R. Fernandez-Alba (2000). "Multiresidue method for the analysis of five antifouling agents in marine and coastal waters by gas chromatography-mass spectrometry with large-volume injection." Journal of Chromatography A 889(1-2): 261-269.

Albanis, T. A., D. A. Lambropoulou, V. A. Sakkas and I. K. Konstantinou (2002). "Antifouling paint booster biocide contamination in Greek marine sediments." Chemosphere 48(5): 475-485.

Ames, A. L., E. S. Van Vleet and C. Dawes (2007). "Characterizaion of Lipids in Aquatic Vegetation from the West Coast of Florida." Florida Scientist 70: 264-274.

Balcomb, R., J. R. Hoberg and J. M. Giddings (2002). "Fate and toxicity of the algicide Irgarol 1051: A marine microcosm study." Bulletin of Environmental Contamination and Toxicology 69(5): 696-703.

Bard, J. and A. Pedersen (1992). "Ecotoxicological evaluation of the antifouling compound 2-(tert-butylamino)-4-(cyclopropylamino)-6-(methylthio)-1,3,5-traizine, Irgarol." Solna, Sweden: Swedish National Chemicals Inspectorate (KEMI).

Berard, A., U. Dorigo, I. Mercier, K. B. van Slooten, D. Grandjean and C. Leboulanger (2003). "Comparison of the ecotoxicological impact of the triazine Irgarol 1051 and atrazine on microalgal cultures and natural microalgal communities in Lake Geneva." Chemosphere 53: 935-944.

Biselli, S., K. Bester, H. Huhnerfuss and K. Fent (2000). "Concentrations of the Antifouling Compound Irgarol 1051 and of Organotins in Water and Sediments of German North and Baltic Sea Marinas." Marine Pollution Bulletin 40: 233-243.

Boger, P. and G. Sandman (1998). Action of Modern Herbicides. Photosynthesis: A Comprehensive Treatise. A. S. Raghavendra, Cambridge University Press, Cambridge: $337-351$.

Bowman, J. C., J. W. Readman and J. L. Zhou (2003). "Seasonal variability in the concentrations of Irgarol 1051 in Brighton Marina, UK, including the impact of dredging." Marine Pollution Bulletin 46(4): 444-451. 
Boxall, A. B. A., S. D. Comber, A. U. Conrad, J. Howcroft and N. Zaman (2000). "Inputs, Monitoring, and Fate Modelling of Antifouling Biocides in UK Estuaries." Marine Pollution Bulletin 40: 898-905.

Carbery, K., R. Owen, T. Frickers, E. Otero and J. Readman (2006). "Contamination of Caribbean coastal waters by the antifouling herbicide Irgarol 1051." Marine Pollution Bulletin 52(6): 635-644.

Carlson, P. R. and K. Madley (2007). Seagrass Status and Trends in the Northern Gulf of Mexico, 1940-2002. Reston, Va : U.S. Department of the Interior, U.S. Geological Survey, Gulf of Mexico Program (U.S.), United States Environmental Protection Agency, Geological Survey (U.S.).

Ciba-Geigy (2004). Ciba IRGAROL 1051, Algicide. C. S. C. Inc.: 1-4.

Dahl, B. and H. Blanck (1996). "Toxic effects of the antifouling agent Irgarol 1051 on periphyton communities in coastal water microcosms." Marine Pollution Bulletin 32(4): 342-350.

de Almeida Azevedo, D., S. Lacorte, T. Vinhas, P. Viana and D. Barcelo (2000). "Monitoring of priority pesticides and other organic pollutants in river water from Portugal by gas chromatography-mass spectrometry and liquid chromatographyatmospheric pressure chemical ionization mass spectrometry." Journal of Chromatography A 879(1): 13-26.

Devilla, R. A., M. T. Brown, M. Donkin and J. W. Readman (2005). "The effects of a PSII inhibitor on phytoplankton community structure as assessed by HPLC pigment analyses, microscopy and flow cytometry." Aquatic Toxicology 71(1): 25-38.

Di Landa, G., G. Ansanelli, R. Ciccoli and C. Cremisini (2006). "Occurrence of antifouling paint booster biocides in selected harbors and marinas inside the Gulf of Napoli: a preliminary survey." Marine Pollution Bulletin 52(11): 1541-1546.

Duarte, C. M. (1995). "Submerged aquatic vegetation in relation to different nutrient regimes." Ophelia 41: 87-112. 
Durako, M. J. and J. I. Kunzelman (2002). "Photosynthetic characteristics of Thalassia testudinum measured in situ by pulse-amplitude modulated (PAM) fluorometry: methodological and scale based considerations." Aquatic Botany 1562: 1-13.

Dyer, R. A., L. E. Tolhurst, M. J. Hilton and K. V. Thomas (2006). "Bioaccumulation of the antifouling paint booster biocide Irgarol 1051 by the green alga Tetraselmis suecica." Bulletin of Environmental Contamination and Toxicology 77(4): 524-532.

Enriquez, S., M. Merino and R. Iglesias-Prieto (2002). "Variations in the photosynthetic performance along the leaves of the tropical seagrass Thalassia testudinum." Marine Biology 140(5): 891-900.

Erftemeijer, P. L. A. and J. J. Middelburg (1995). "Mass balance constraints on nutrient cycling in tropical seagrass Beds." Aquatic Botany 50: 21-36.

F.D.o.E.P. (2001). Miami River. Assessment and Monitoring Program. Miami-Dade County, Florida Department of Environmental Protection. August.

Fernandez-Alba, A. R., L. Piedra, M. Mezcua and M. D. Hernando (2002). "Toxicity of single and mixed contaminants in seawater measured with acute toxicity bioassays." Scientific World Journal 2: 1115-1120.

Ferrer, I., B. Ballesteros, M. Marco and D. Barcelo (1997). "Pilot Survey for Determination of the Antifouling Agent Irgarol 1051 in Enclosed Seawater Samples by a Direct Enzyme-Linked Immunosorbent Assay and Solid Phase Extraction Followed by Liquid Chromatorgraphy-Diode Array Detection." Environmental Science and Technology 31: 3530-3535.

Ferrer, I., Barcelo, D. (1999). "Simultaneous determination of antifouling herbicides in marina water samples by on-line solid-phase extraction followed by liquid chromatography-mass spectrometry." Journal of Chromatography A 854: 221-228.

Florida Fish and Wildlife Conservation Commission, F. W. (2003). Conserving Florida's seagrass resources: Developing a coordinated statewide management program. St. Petersburg, FL, Florida Fish and Wildlife Conservation Commission. 
Fong, P. and M. A. Harwell (1994). "Modeling seagrass communities in tropical and subtropical bays and estuaries: A mathematical model synthesis of current hypotheses." Bulletin of Marine Science 54: 757-781.

Fourqurean, J. W., M. J. Durako, M. O. Hall, L. N. Hefty (2001). "Seagrass distribution in south Florida: a multi-agency coordinated monitoring program." The Everglades, Florida Bay, and Coral Reefs of the Florida Keys: An Ecosystem Sourcebook: 497522.

Gardinali, P. R., M. Plasencia, S. Mack and C. Poppell (2002). "Occurrence of IRGAROL 1051 in coastal waters from Biscayne Bay, Florida, USA." Marine Pollution Bulletin 44(8): 781-788.

Gardinali, P. R., M. D. Plasencia and C. Maxey (2004). "Occurrence and transport of Irgarol 1051 and its major metabolite in coastal waters from South Florida." Marine Pollution Bulletin 49(11-12): 1072-1083.

Gatidou, G., N. S. Thomaidis and J. L. Zhou (2007). "Fate of Irgarol 1051, diuron and their main metabolites in two UK marine systems after restrictions in antifouling paints." Environment International 33(1): 70-77.

Gough, M. A., J. Fothergill and J. D. Hendrie (1994). "A survey of Southern England coastal waters for the s-triazine antifouling compound Irgarol 1051." Marine Pollution Bulletin 28: 613-630.

Haglund, K., A. Pettersson, M. Peterson, H. Kylin, S. C. Lord and P. Dollenmeier (2001). "Seasonal distribution of the antifouling compound Irgarol 1051 outside a marina in the Stockholm archipelago." Bulletin of Environmental Contamination and Toxicology 66(1): 50-58.

Hall, L. W., J. M. Giddings, K. R. Solomon and R. Balcomb (1999). "An ecological risk assessment for the use of Irgarol 1051 as an algaecide for antifoulant paints." Critical Reviews in Toxicology 29(4): 367-437.

Hall, L. W., Jr., W. D. Killen, R. D. Anderson, R. Balcomb and P. Gardinali (2009). "Ecological risk of Irgarol 1051 and its major metabolite in coastal California marinas and reference areas." Marine Pollution Bulletin 58(5): 702-710. 
Hall, L. W., Jr., W. D. Killen and P. R. Gardinali (2004). "Occurrence of Irgarol 1051 and its major metabolite in Maryland waters of Chesapeake Bay." Marine Pollution Bulletin 48(5-6): 554-562.

Hall, L. W. and W. D. Killen (2001). A pilot monitoring study for Irgarol 1051 and its major metabolite in Maryland Waters of Chesapeake Bay. Queenstown, MD, University of Maryland, Wye Research and Education Center.

Hall, L. W., W. D. Killen, R. D. Anderson, P. R. Gardinali and R. Balcomb (2005). "Monitoring of Irgarol 1051 concentrations with concurrent phytoplankton evaluations in East Coast areas of the United States." Marine Pollution Bulletin 50(6): 668-681.

Harino, H., M. Ohji, G. Wattayakorn, T. Arai, S. Rungsupa and N. Miyazaki (2006). "Occurrence of antifouling biocides in sediment and green mussels from Thailand." Archives of Environmental Contamination and Toxicology 51(3): 400-407.

Harino, H., Y. Yamamoto, S. Eguchi, S. Kawai, Y. Kurokawa, T. Arai, M. Ohji, H. Okamura and N. Miyazaki (2007). "Concentrations of antifouling biocides in sediment and mussel samples collected from Otsuchi bay, Japan." Archives of Environmental Contamination and Toxicology 52(2): 179-188.

Hernando, M. D., L. Piedra, A. Belmonte, A. Aguera and A. R. Fernandez-Alba (2001). "Determination of traces of five antifouling agents in water by gas chromatography with positive/negative chemical ionization and tandem mass spectrometric detection." Journal of Chromatography A 938: 103-111.

Hoberg, J. R. (1998a). Irgarol 1051 - Toxicity to a Marine Dinoflagellate, Dunaliella teriolecta. Report No. 98-2-7260. Wareham, MA, Springborn Laboratories, Inc.

Hoberg, J. R. (1998b). Irgarol 1051 - Toxicity to a Marine Green Algae, Chlorococum sp. Report No. 98-2-7259. Wareham, MA, Springborn Laboratories, Inc.

Hock, B. and E. F. Elstner (2005). Plant Toxicology. New York, Marcel Dekker.

Hogarth, P. J. (2007). The Biology of Mangroves and Seagrasses. Oxford, New York, Oxford University Press. 
Hughes, J. and M. M. Alexander (1993). The toxicity of Irgarol 1051 to Selenastrum capricornutum. Study ID B267-582-1. Tarrytown, NY, Malcolm Pirnie, Inc.

Hughes, J., Alexander, M.M. (1993). The toxicity of Irgarol 1051 to Skeletonema costatum, B267-582-4.

Jones, R. J. and A. P. Kerswell (2003). "Phytotoxicity of photosystem II (PSII) herbicides to coral." Marine Ecology Progress Series 261: 149-159.

Kitada, U., H. Kawahata, A. Suzuki and T. Oomori (2008). "Distribution of pesticides and bisphenol A in sediments collected from rivers adjacent to coral reefs." Chemosphere 71(11): 2082-2090.

Konstantinou, I. K. and T. A. Albanis (2004). "Worldwide occurrence and effects of antifouling paint booster biocides in the aquatic environment: a review." Environment International 30(2): 235-248.

Lam, K. H., Z. Cai, H. Y. Wai, V. W. Tsang, M. H. Lam, R. Y. Cheung, H. Yu and P. K. Lam (2005). "Identification of a new Irgarol-1051 related s-triazine species in coastal waters." Environmental Pollution 136(2): 221-230.

Lam, K. H., M. H. Lam, P. K. Lam, T. Qian, Z. Cai, H. Yu and R. Y. Cheung (2004). "Identification and characterization of a new degradation product of Irgarol-1051 in mercuric chloride-catalyzed hydrolysis reaction and in coastal waters." Marine Pollution Bulletin 49(4): 361-367.

Lam, K. H., N. Y. Lei, V. W. Tsang, Z. Cai, K. M. Leung and M. H. Lam (2009). "A mechanistic study on the photodegradation of Irgarol-1051 in natural seawater." Marine Pollution Bulletin 58(2): 272-279.

Lambert, S. J., K. V. Thomas and A. J. Davy (2006). "Assessment of the risk posed by the antifouling booster biocides Irgarol 1051 and diuron to freshwater macrophytes." Chemosphere 63(5): 734-743.

Lamoree, M. H., C. P. Swart, A. van der Horst and B. van Hattum (2002). "Determination of diuron and the antifouling paint biocide irgarol 1051 in Dutch marinas and coastal waters." Journal of Chromatography A 970(1-2): 183-190. 
Lirman, D. and J. Cropper, W.P. (2003). "The Influence of Salinity on Seagrass Growth, Survivorship, and Distribution within Biscayne Bay, Florida: Field, Experimental, and Modeling Studies." Estuaries 26(1): 131-141.

Liu, D., R. J. Maguire, Y. L. Lau, G. J. Pacepavicius, H. Okamura and I. Aoyama (1997). "Transformation of the new antifouling compound Irgarol 1051 by Phanerochaete chrysosporium." Water Research 31(9): 2363-2369.

Liu, D., G. J. Pacepavicius, R. J. Maguire, Y. L. Lau, H. Okamura and I. Aoyama (1999). "Mercuric chloride-catalyzed hydrolysis of the new antifouling compound Irgarol 1051." Water Research 33(1): 155-163.

Martinez, K., I. Ferrer, M. D. Hernando, A. R. Fernandez-Alba, R. M. Marce, F. Borrull and D. Barcelo (2001). "Occurrence of antifouling biocides in the Spanish Mediterranean marine environment." Environmental Technology 22: 543-552.

Maxey, C. (2006). Occurrence and Distribution of Irgarol 1051 and its Natural Metabolites in Biotic and Abiotic Marine Samples. Chemistry. Miami, FL, Florida International University. M.S.

Mazzella, L. and R. S. Alberte (1986). "Light adaptation and the role of autotrophic epiphytes in primary production of temperate seagrass, Zostera marina (L.)." Journal of Experimental Marine Biology and Ecology 100: 165-180.

Mohr, S., R. Berghahn, W. Mailahn, R. Schmiediche, M. Feibicke and R. Schmidt (2009). "Toxic and accumulative potential of the antifouling biocide and TBT successor irgarol on freshwater macrophytes: a pond mesocosm study." Environmental Science and Technology 43(17): 6838-6843.

Mohr, S., H. Schroder, M. Feibicke, R. Berghahn, W. Arp and A. Nicklisch (2008). "Long-term effects of the antifouling booster biocide Irgarol 1051 on periphyton, plankton and ecosystem function in freshwater pond mesocosms." Aquatic Toxicology 90(2): 109-120.

Nystrom, B., K. Becker-Van Slooten, A. Berard, D. Grandjean, J. C. Druart and C. Leboulanger (2002). "Toxic effects of Irgarol 1051 on phytoplankton and macrophytes in Lake Geneva." Water Research 36(8): 2020-2028. 
Ogawa, N., H. Okamura, H. Hirai and T. Nishida (2004). "Degradation of the antifouling compound Irgarol 1051 by manganese peroxidase from the white rot fungus Phanerochaete chrysosporium." Chemosphere 55(3): 487-491.

Okamura, H. (2002). "Photodegradation of the antifouling compounds Irgarol 1051 and Diuron released from a commercial antifouling paint." Chemosphere 48(1): 43-50.

Okamura, H., I. Aoyama, D. Liu, J. Maguire, G. J. Pacepavicius and Y. L. Lau (1999). "Photodegradation of Irgarol 1051 in water." Journal of Environmental Science and Health Part B - Pesticides Food Contaminants and Agricultural Wastes 34(2): 225238.

Okamura, H., I. Aoyama, D. Liu, R. J. Maguire, G. J. Pacepavicius and Y. L. Lau (2000a). "Fate and ecotoxicity of the new antifouling compound Irgarol 1051 in the aquatic environment." Water Research 34(14): 3523-3530.

Okamura, H., I. Aoyama, T. Takami, T. Maruyama, Y. Suzuki, M. Matsumoto, I. Katsuyama, J. Hamada, T. Beppu, O. Tanaka, R. J. Maguire, D. Liu, Y. L. Lau and G. J. Pacepavicius (2000b). "Phytotoxicity of the new antifouling compound Irgarol 1051 and a major degradation product." Marine Pollution Bulletin 40(9): 754-763.

Okamura, H. and Y. Sugiyama (2004). "Photosensitized degradation of Irgarol 1051 in water." Chemosphere 57(7): 739-743.

Owens, R., A. Knap, M. Toaspern and K. Carbery (2002). "inhibition of coral photosynthesis by the antifouling herbicide Irgarol 1051." Marine Pollution Bulletin 44: 623-632.

Pocurull, E., L. Brossa, F. Borrull and R. M. Marce (2000). "Trace determination of antifouling compounds by on-line solid-phase extraction-gas chromatography-mass spectrometry." Journal of Chromatography A 885(1-2): 361-368.

Ranke, J. and B. Jastorff (2000). "Multidimensional risk analysis of antifouling biocides." Environmental Science and Pollution Research International 7(2): 105-114.

Readman, J. W. (2006). Development, Occurrence and Regulation of Antifouling Paint Biocides: Historical Review and Future Trends. Antifouling Paint Biocides. S. B. Heidelberg. 5: 1-15. 
Readman, J. W., L. L. W. Kwong, D. Grondin, J. Bartocci, J. P. Villanueve and L. D. Mee (1993). "Coastal water contamination from a triazine herbicide used in antifouling paints." Environmental Science and Technology 27: 1940-1942.

Rogers, H. R., C. D. Watts and I. Jonshon (1996). "Comparative predictions of Irgarol 1051 and atrazine fate and toxicity." Environmental Technology 17: 553-556.

Sakkas, V. A., D. A. Lambropoulou and T. A. Albanis (2002). "Photochemical degradation study of Irgarol 1051 in natural waters: influence of humic and fulvic substances on the reaction." Journal of Photochemistry and Photobiology A: Chemistry 147: 135-141.

Sapozhnikova Y., W. E., Singhasemanon N., Bacey J., Fulton M. (2008). "Distribution of antifouling biocides in California marinas." Journal of Environmental Monitoring 10(1069-1075).

Sargent, C. J., J. C. Bowman and J. L. Zhou (2000). "Levels of antifoulant Irgarol 1051 in the Conwy Marina, North Wales." Chemosphere 41(11): 1755-1760.

Scarlett, A., M. E. Donkin, T. W. Fileman and P. Donkin (1997). "Occurrence of the marine antifouling agent Irgarol 1051 within the Plymouth Sound locality: Implications for the green macroalga Enteromorpha intestinalis." Marine Pollution Bulletin 34: 645-651.

Scarlett, A., P. Donkin, T. W. Fileman, S. V. Evans and M. E. Donkin (1999a). "Risk posed by the antifouling agent Irgarol 1051 to the seagrass, Zostera marina." Aquatic Toxicology 45(2-3): 159-170.

Scarlett, A., P. Donkin, T. W. Fileman and R. J. Morris (1999b). "Occurrence of the antifouling herbicide, Irgarol 1051, within coastal-water seagrasses from Queensland, Australia." Marine Pollution Bulletin 38(8): 687-691.

Stapel, J., T. L. Aarts, B. H. M. van Duynhoven, J. D. de Groot, P. H. W. van den Hoogen and M. A. Hemminga (1996). "Nutrient uptake by leaves and roots of the seagrass Thalassia hemprichii in the Spermonde Archipelago, Indonesia." Marine Ecology Progress Series 143: 195-206. 
Steen, R. J. C. A., P. E. G. Leonards, U. A. T. Brinkman and W. P. Cofino (1997). "Ultra-trace-level determination of the antifouling agent Irgarol 1051 by gas chromatography with tandem mass spectrometric detection." Journal of Chromatography A 766(1-2): 153-158.

Thomas, K. V., T. W. Fileman, J. W. Readman and M. J. Waldock (2001). "Antifouling paint booster biocides in the UK coastal environment and potential risks of biological effects." Marine Pollution Bulletin 42(8): 677-688.

Thomas, K. V., M. McHugh and M. Waldock (2002). "Antifouling paint booster biocides in UK coastal waters: inputs, occurrence and environmental fate." Science of the Total Environment 293(1-3): 117-127.

Tolosa, I., J. W. Readman, A. Blaevoet, S. Ghilini, J. Bartocci and M. Horvat (1996). "Contamination of Mediterranean (Cote d'Azur) coastal waters by organotins and irgarol 1051 used in antifouling paints." Marine Pollution Bulletin 32: 335-341.

Toth, S., S. K. Becker-van, L. F. Spack, F. Alencastro and J. Tarradellas (1996). "Irgarol 1051: an antifouling compound in freshwater sediment and biota of Lake Geneva." Bulletin of Environmental Contamination and Toxicology 57: 426-433.

van Tussenbroek, B. I., J. A. Vonk, J. Stapel, P. L. A. Erftemeijer, J. J. Middelburg and J. C. Zieman (2006). "The Biology of Thalassia: Paradigms and Recent Advances in Research." Seagrasses: biology, ecology, and conservation: 409-439.

Voulvoulis, N., M. D. Scrimshaw and J. N. Lester (2000). "Occurrence of four biocides utilized in antifouling paints, as alternatives to organotin compounds, in waters and sediments of a commercial estuary in the UK." Marine Pollution Bulletin 40: 938946.

Zamora-Ley, I. M., P. R. Gardinali and F. J. Jochem (2006). "Assessing the effects of Irgarol 1051 on marine phytoplankton populations in Key Largo Harbor, Florida." Marine Pollution Bulletin 52(8): 935-941.

Zhang, A. Q., K. M. Leung, K. W. Kwok, V. W. Bao and M. H. Lam (2008). "Toxicities of antifouling biocide Irgarol 1051 and its major degraded product to marine primary producers." Marine Pollution Bulletin 57(6-12): 575-586. 
Zhou, J. K., T. W. Fileman, S. Evans, P. Donkin, R. F. C. Mantoura and J. S. Rowland (1996). "Seasonal distribution of dissolved pesticides and polynuclear aromatic hydrocarbons in the Humber estuary and Humber coastal zone." Marine Pollution Bulletin 32: 599-608.

Zhou, J. L. (2008). "Occurrence and persistence of antifouling biocide Irgarol 1051 and its main metabolite in the coastal waters of Southern England." Science of the Total Environment 406(1-2): 239-246. 


\section{APPENDIX}

APPENDIX A. Worldwide distribution of Irgarol.

\begin{tabular}{|c|c|c|c|c|}
\hline Location & Date & $\begin{array}{c}\text { Water } \\
\text { (ng L-1) }\end{array}$ & $\begin{array}{c}\text { Sediment } \\
\text { (ng g-1) }\end{array}$ & Reference \\
\hline \multicolumn{5}{|c|}{ United Kingdom } \\
\hline \multicolumn{5}{|l|}{ Marinas } \\
\hline Kent, Sussex, Hampshire & August 1993 & $52-500$ & N.S. & (Gough et al. 1994) \\
\hline Sutton Harbour & April - October 1998 & $<1-69$ & N.S. & (Thomas et al. 2001) \\
\hline Plymouth Sound & July - August 1995 & $28-127$ & N.S. & (Scarlett et al. 1997) \\
\hline Conwy, Wales & January - March 1999 & $7-543$ & N.S. & (Sargent et al. 2000) \\
\hline Southern coast & January - October 1998 & $<1-1421$ & N.S. & (Thomas et al. 2001) \\
\hline \multirow[t]{3}{*}{ Brighton } & November 1999 - January 2001 & $<1-964$ & $<1-77$ & (Bowman et al. 2003) \\
\hline & March 2003 - February 2004 & $<0.5-36.9$ & $<0.9-5.6$ & (Gatidou et al. 2007) \\
\hline & August 2004 - May 2005 & $<3.1-22$ & $<1.7-17$ & (Zhou 2008) \\
\hline Humber & April - September 1995 & $169-682$ & N.S. & (Zhou et al. 1996) \\
\hline Orwell & September 1998 - February 1999 & $5.6-201.4$ & $<10-1011$ & (Boxall et al. 2000) \\
\hline Hamble & September 1998 - February 1999 & $18.3-61.1$ & $<10$ & (Boxall et al. 2000) \\
\hline Hythe & August 2004 - May 2005 & $<3.1-18$ & $<1.7-32$ & (Zhou 2008) \\
\hline Gosport & August 2004 - May 2005 & $<3.1-15$ & $<1.7-25$ & (Zhou 2008) \\
\hline Port Solent & August 2004 - May 2005 & $11-89$ & $3-45$ & (Zhou 2008) \\
\hline \multicolumn{5}{|l|}{ Estuaries } \\
\hline \multirow[t]{3}{*}{ Hamble } & July - September 1993 & $12-190$ & $12-132$ & (Gough et al. 1994) \\
\hline & September 1998 - February 1999 & $7.3-17.9$ & $<10$ & (Boxall et al. 2000) \\
\hline & April - October 1998 & $<1-141$ & N.S. & (Thomas et al. 2001) \\
\hline Humber & April - September 1995 & $<1-39$ & N.S. & (Zhou et al. 1996) \\
\hline Southern coast & January - October 1998 & $<1-32$ & N.S. & (Thomas et al. 2001) \\
\hline Medway & August 1993 & $4-18$ & N.S. & (Gough et al. 1994) \\
\hline
\end{tabular}


APPENDIX A. Continued.

\begin{tabular}{|c|c|c|c|c|}
\hline Location & $\begin{array}{r}\text { Date } \\
\end{array}$ & $\begin{array}{r}\text { Water } \\
\text { (ng/L) }\end{array}$ & $\begin{array}{c}\text { Sediment } \\
\text { (ng/g) }\end{array}$ & Reference \\
\hline Blackwater, Essex & October 1998 - June 1998 & $150-680$ & $3.3-222$ & (Voulvoulis et al. 2000) \\
\hline River Crouch & April - October 1998 & $<1-49$ & N.S. & (Thomas et al. 2001) \\
\hline Yealm and Salcombe & Summer 1997 - Spring 1998 & $<3-10$ & N.S. & (Scarlett et al. 1999a) \\
\hline \multirow[t]{2}{*}{ Southampton Water } & April - October 1998 & $<1-403$ & N.S. & (Thomas et al. 2001) \\
\hline & Summer 2000 & $<1-305$ & $0.3-3.5$ & (Thomas et al. 2002) \\
\hline \multicolumn{5}{|l|}{ Ports, Coastal areas } \\
\hline \multirow[t]{2}{*}{ Kent, Sussex, Hampshire } & August 1993 & $9-14$ & N.S. & (Gough et al. 1994) \\
\hline & July - September & $<2-11$ & N.S. & (Gough et al. 1994) \\
\hline \multicolumn{5}{|l|}{ Harbor } \\
\hline Newhaven & August 2004 - May 2005 & $<3.1-27$ & $<1.7-18$ & (Zhou 2008) \\
\hline \multirow[t]{2}{*}{ Shoreham } & August 2004 - May 2005 & $<3.1-45$ & $<1.7-38$ & (Zhou 2008) \\
\hline & March 2003 - February 2004 & $<0.5-58,9$ & $<0.9-22.7$ & (Gatidou et al. 2007) \\
\hline \multicolumn{5}{|c|}{ France } \\
\hline \multicolumn{5}{|l|}{ Marinas } \\
\hline Co^te d' Azur & June 1992 & $110-1700$ & N.S. & (Readman et al. 1993) \\
\hline \multirow[t]{2}{*}{ Riviera, Monaco } & May - June 1995 & $22-640$ & N.S. & (Tolosa et al. 1996) \\
\hline & & $132-275$ & N.S. & (Tolosa et al. 1996) \\
\hline \multicolumn{5}{|l|}{ Ports } \\
\hline Co^te d' Azur & June 1992 & $<5-280$ & N.S. & (Readman et al. 1993) \\
\hline Riviera, Monaco & May - June 1995 & $13.8-264$ & N.S. & (Tolosa et al. 1996) \\
\hline \multicolumn{5}{|l|}{ Beaches } \\
\hline Co^te d'Azur & June 1992 & N.D. & N.S. & (Readman et al. 1993) \\
\hline Riviera, Monaco & May - June 1995 & $<1.5--1$ & N.S. & (Tolosa et al. 1996) \\
\hline
\end{tabular}


APPENDIX A. Continued.

\begin{tabular}{|c|c|c|c|c|}
\hline Location & Date & $\begin{array}{l}\text { Water } \\
\text { (ng/L) }\end{array}$ & $\begin{array}{c}\text { Sediment } \\
\text { (ng/g) }\end{array}$ & Reference \\
\hline \multicolumn{5}{|l|}{ Spain } \\
\hline \multicolumn{5}{|l|}{ Marinas } \\
\hline \multirow[t]{3}{*}{ Catalonia } & $1996-1997$ & $7-325$ & N.S. & (Ferrer et al. 1997) \\
\hline & January - August 1999 & $<50$ & N.S. & (Martinez et al. 2001) \\
\hline & April 1996 - January 1999 & $15-320$ & N.S. & (Ferrer 1999) \\
\hline Barcelona (Masnou) & February 1997 - June 1998 & N.D. - 119 & $3-57$ & (Ferrer 1999) \\
\hline Almeria & & $25-450$ & N.S. & (Aguera et al.) \\
\hline Tarragona-Cambrils & March - June 1999 & $<10-50$ & N.S. & (Pocurull et al.) \\
\hline Southeast Spain & & $50-1000$ & N.S. & (Hernando et al.) \\
\hline \multicolumn{5}{|c|}{ Greece } \\
\hline \multicolumn{5}{|l|}{ Marinas } \\
\hline Piraeus-Elefsina & October 1999 - September 2000 & N.D. -90 & N.D. - 690 & (Sakkas et al. 2002) \\
\hline Thessaloniki & & N.D. - 68 & $75-350$ & (Albanis et al. 2002) \\
\hline Patras & & $12-24$ & N.D. - 37 & (Albanis et al. 2002) \\
\hline Chalkida & & N.D. & N.D. -88 & (Albanis et al. 2002) \\
\hline Igoumenitsa-Aktio & & N.D. - 27 & N.D. - 74 & (Albanis et al. 2002) \\
\hline \multicolumn{5}{|l|}{ Ports } \\
\hline Piraeus & October 1999 - September 2000 & $10-24$ & N.D. - 19 & (Sakkas et al. 2002) \\
\hline Thessaloniki & & N.D. & N.D. - 11 & (Albanis et al. 2002) \\
\hline Patras & & N.D. & N.D. - 11 & (Albanis et al. 2002) \\
\hline \multicolumn{5}{|c|}{ Netherlands } \\
\hline \multicolumn{5}{|l|}{ Marinas } \\
\hline Dutch coast & April - November 2000 & $8-90$ & N.S. & (Lamoree et al. 2002) \\
\hline
\end{tabular}


APPENDIX A. Continued.

\begin{tabular}{|c|c|c|c|c|}
\hline Location & Date & $\begin{array}{l}\text { Water } \\
\text { (ng/L) }\end{array}$ & $\begin{array}{c}\text { Sediment } \\
\text { (ng/g) }\end{array}$ & Reference \\
\hline \multicolumn{5}{|l|}{ Estuaries } \\
\hline \multirow[t]{2}{*}{ Western Scheldt } & 33694 & $1.6-10$ & N.S. & (Steen et al. 1997) \\
\hline & April 1996 - March 1997 & $8-37$ & N.S. & (Steen et al. 1997) \\
\hline \multicolumn{2}{|l|}{ Sas Gent Schaar van Ouden } & $5-42$ & N.S. & (Hall et al. 1999) \\
\hline \multicolumn{5}{|c|}{ Japan } \\
\hline \multicolumn{5}{|l|}{ Shipyard } \\
\hline Otsuchi Bay & July 2005 & $<0.05-21$ & N.S. & (Harino et al. 2007) \\
\hline \multicolumn{5}{|l|}{ Fishing Port } \\
\hline Otsuchi Bay & July 2005 & $0.15-100$ & N.S. & (Harino et al. 2007) \\
\hline \multicolumn{5}{|l|}{ River Mouth } \\
\hline \multirow[t]{2}{*}{ Tairawan } & July 2004 & & N.D. & (Kitada et al. 2008) \\
\hline & September 2005 & & N.D. & (Kitada et al. 2008) \\
\hline \multirow[t]{2}{*}{ Manna River } & July 2004 & & 0.12 & (Kitada et al. 2008) \\
\hline & September 2005 & & $<0.016$ & (Kitada et al. 2008) \\
\hline \multirow[t]{2}{*}{ Hija River } & July 2004 & & 0.02 & (Kitada et al. 2008) \\
\hline & September 2005 & & 0.051 & (Kitada et al. 2008) \\
\hline \multirow[t]{2}{*}{ K-2 } & July 2004 & & 0.029 & (Kitada et al. 2008) \\
\hline & September 2005 & & 0.034 & (Kitada et al. 2008) \\
\hline \multicolumn{5}{|c|}{ Thailand } \\
\hline \multicolumn{5}{|l|}{ River Mouth } \\
\hline Sattahip, Conburi & April 2004 & N.S. & 3.2 & (Harino et al. 2006) \\
\hline Bangpakong River & April 2004 & N.S. & 0.98 & (Harino et al. 2006) \\
\hline Chao Phraya River & April 2004 & N.S. & 0.85 & (Harino et al. 2006) \\
\hline
\end{tabular}


APPENDIX A. Continued.

\begin{tabular}{|c|c|c|c|c|}
\hline Location & Date & $\begin{array}{l}\text { Water } \\
\text { (ng/L) }\end{array}$ & $\begin{array}{c}\text { Sediment } \\
\text { (ng/g) }\end{array}$ & Reference \\
\hline \multicolumn{5}{|l|}{ Italy } \\
\hline \multicolumn{5}{|l|}{ Harbors } \\
\hline Pozzuoli porto & October 2004 & 4.9 & N.S. & (Di Landa et al. 2006) \\
\hline Castellammare di Stabia & October 2004 & 8.2 & N.S. & (Di Landa et al. 2006) \\
\hline Sorrento & October 2004 & 3.5 & N.S. & (Di Landa et al. 2006) \\
\hline \multicolumn{5}{|l|}{ Marina } \\
\hline Miseno & October 2004 & 22 & N.S. & (Di Landa et al. 2006) \\
\hline Baia & October 2004 & 9.5 & N.S. & (Di Landa et al. 2006) \\
\hline Pozzuoli Marina di Maglietta & October 2004 & 29 & N.S. & (Di Landa et al. 2006) \\
\hline Piano di Sorrento & October 2004 & 4.0 & N.S. & (Di Landa et al. 2006) \\
\hline Massa Lubrense & October 2004 & 4.7 & N.S. & (Di Landa et al. 2006) \\
\hline \multicolumn{5}{|c|}{$\begin{array}{ll}\text { Switzerland } \\
\end{array}$} \\
\hline Lake Geneva & August 1994 - April 1995 & $2.5-145$ & $2.5-8$ & (Toth et al. 1996) \\
\hline & 34942 & N.D. -135 & & (Nystrom et al. 2002) \\
\hline \multicolumn{5}{|l|}{ Germany } \\
\hline \multicolumn{5}{|l|}{ Marinas } \\
\hline North Sea & July - September 1997 & $11-170$ & 38800 & (Biselli et al. 2000) \\
\hline Baltic Sea & July - September 1997 & $80-440$ & $4-220$ & (Biselli et al. 2000) \\
\hline \multicolumn{5}{|c|}{ Portugal } \\
\hline \multicolumn{5}{|l|}{ River water } \\
\hline Ponte Aranha & April - July 1999 & $10-260$ & N.S. & $\begin{array}{l}\text { (de Almeida Azevedo et } \\
\text { al. 2000) }\end{array}$ \\
\hline
\end{tabular}


APPENDIX A. Continued.

\begin{tabular}{|c|c|c|c|c|}
\hline Location & Date & $\begin{array}{l}\text { Water } \\
\text { (ng/L) }\end{array}$ & $\begin{array}{c}\text { Sediment } \\
\text { (ng/g) }\end{array}$ & Reference \\
\hline \multicolumn{5}{|c|}{ Sweden } \\
\hline \multicolumn{5}{|l|}{ Marinas } \\
\hline Fiskebäckskil (West coast) & June 1993 - September 1994 & $30-400$ & N.S. & (Dahl et al. 1996) \\
\hline Karlslund, Sth Stockholm & April 1996 - November 1996 & $4-125$ & 38756 & (Haglund et al. 2001) \\
\hline \multicolumn{5}{|c|}{ USA } \\
\hline \multicolumn{5}{|l|}{ Biscayne Bay } \\
\hline Marinas & March 1999 - September 2000 & $<1-15.2$ & N.S. & (Gardinali et al. 2002) \\
\hline Ports & March 1999 - September 2000 & $<1-1.1$ & N.S. & (Gardinali et al. 2002) \\
\hline Miami River & March 1999 - September 2000 & $<1-60.9$ & N.S. & (Gardinali et al. 2002) \\
\hline Florida Keys Marinas & September - October 2001 & $<1-182$ & N.S. & (Gardinali et al. 2002) \\
\hline Florida & Summer 2001 & $12.2-144.2$ & N.S. & (Owens et al. 2002) \\
\hline \multicolumn{5}{|l|}{ East Coast } \\
\hline Maryland Marina & May 2001 - September 2001 & $16.4-63.1$ & N.S. & (Hall et al. 2001) \\
\hline Chesapeake Harbor & May 2001 - September 2001 & $10.1-79.8$ & N.S. & (Hall et al. 2001) \\
\hline Port Annapolis & May 2001 - September 2001 & $188-412$ & N.S. & (Hall et al. 2001) \\
\hline Piney Narrows & May 2001 - September 2001 & $2.05-27.1$ & N.S. & (Hall et al. 2001) \\
\hline Severn River & May 2001 - September 2001 & $32.9-170$ & N.S. & (Hall et al. 2001) \\
\hline Back Creek/Severn River & Summer 2003 - 2004 & $5-1816$ & N.S. & (Hall et al. 2005) \\
\hline Carolinian Province & Summer 2003 - 2004 & N.D. -85 & N.S. & (Hall et al. 2005) \\
\hline \multicolumn{5}{|l|}{ West Coast } \\
\hline Berkeley Marina & 2006 & $1.7-84.3$ & N.S. & (Hall et al. 2009) \\
\hline Kings Harbor & 2006 & $1.45-339$ & N.S. & (Hall et al. 2009) \\
\hline Pier 39 Marina & 2006 & $0.93-3.11$ & N.S. & (Hall et al. 2009) \\
\hline
\end{tabular}


APPENDIX A. Continued.

\begin{tabular}{|c|c|c|c|c|}
\hline Location & Date & $\begin{array}{l}\text { Water } \\
\text { (ng/L) }\end{array}$ & $\begin{array}{c}\text { Sediment } \\
\text { (ng/g) }\end{array}$ & Reference \\
\hline Shelter Island & 2006 & $0.62-75.8$ & N.S. & (Hall et al. 2009) \\
\hline Marriott San Diego & 2006 & $7.14-39.8$ & N.S. & (Hall et al. 2009) \\
\hline Chula Vista Harbor & 2006 & $8.08-50.6$ & N.S. & (Hall et al. 2009) \\
\hline Dana Point Harbor & 2005 & $138-304$ & N.S. & (Sapozhnikova Y. 2008) \\
\hline Oceanside Harbor & 2005 & $23-64$ & N.S. & (Sapozhnikova Y. 2008) \\
\hline Mission Bay & 2005 & $3-8$ & N.S. & (Sapozhnikova Y. 2008) \\
\hline San Diego Harbor & 2005 & $1-71$ & N.S. & (Sapozhnikova Y. 2008) \\
\hline \multicolumn{5}{|c|}{ Puerto Rico } \\
\hline \multicolumn{5}{|l|}{ Marina } \\
\hline Puerto Del Rey & January - February 2005 & $5-51$ & & (Carbery et al. 2006) \\
\hline San Juan Bay & January - February 2005 & $<1-8$ & & (Carbery et al. 2006) \\
\hline Club Nautico de San Juan & January - February 2005 & $2-23$ & & (Carbery et al. 2006) \\
\hline Cangrejos Yacht Club & January - February 2005 & $<1-1$ & & (Carbery et al. 2006) \\
\hline \multicolumn{5}{|l|}{ Harbour } \\
\hline Villa Marina Yacht & January - February 2005 & $17-42$ & & (Carbery et al. 2006) \\
\hline \multicolumn{5}{|c|}{ U.S. Virgin Islands } \\
\hline \multicolumn{5}{|l|}{ St. Thomas - Marina } \\
\hline American Yacht Harbour & October - December 2004 & $10-91$ & & (Carbery et al. 2006) \\
\hline Benner Bay & October - December 2004 & $228-1300$ & & (Carbery et al. 2006) \\
\hline Charlotte Amalie harbour & October - December 2004 & $<1-6$ & & (Carbery et al. 2006) \\
\hline \multicolumn{5}{|l|}{ St. John - Harbor } \\
\hline Coral Bay & October - December 2004 & $2-19$ & & (Carbery et al. 2006) \\
\hline
\end{tabular}


APPENDIX B. Toxicity data for Irgarol and M1.

\begin{tabular}{|c|c|c|c|c|c|}
\hline Class & Test Organism & Toxicity Index & $\begin{array}{c}\text { Irgarol } \\
\mathrm{EC}_{50}{ }^{\mathrm{a}} \text { or } \mathrm{LC}_{50}{ }^{\mathrm{b}} \\
\end{array}$ & $\begin{array}{c}\text { Irgarol } \\
\text { NOEC }^{\mathrm{c}} \text { or } \\
\text { LOEC }^{\mathrm{d}} \\
\end{array}$ & Reference \\
\hline \multirow[t]{2}{*}{ Seaweed } & Pophyra yezoensis & 4 day $\mathrm{EC}_{50}$ & $6 \times 10^{5}$ & $\leq 300^{\mathrm{c}}$ & (Okamura et al. 2000b) \\
\hline & Eisenia bicyclis & 4 day $\mathrm{EC}_{50}$ & $2.6 \times 10^{6}-7.4 \times 10^{6}$ & $3,200^{c}$ & (Okamura et al. 2000b) \\
\hline Seagrass & Zostera marina & 10 day Growth $\mathrm{EC}_{50}$ & $2.6 \times 10^{3}$ & $5,000^{\mathrm{c}}$ & (Scarlett et al. 1999a) \\
\hline \multirow[t]{6}{*}{ Algae } & $\begin{array}{l}\text { Closterium } \\
\text { ahrengergii }\end{array}$ & 5 day $\mathrm{EC}_{50}$ & $25 \times 10^{6}$ & & (Okamura et al. 2000b) \\
\hline & $\begin{array}{l}\text { Selenastrum } \\
\text { capricorniatum }\end{array}$ & 3 day $\mathrm{EC}_{50}$ & $1.08 \times 10^{7} \pm 1.7 \times 10^{6}$ & $5,000 \pm 900^{d}$ & $\begin{array}{l}\text { (Fernandez-Alba et al. } \\
\text { 2002) }\end{array}$ \\
\hline & & 72 hour Growth & $10.8 \times 10^{3}$ & & $\begin{array}{l}\text { (Fernandez-Alba et al. } \\
\text { 2002) }\end{array}$ \\
\hline & Chlorococcum sp. & $\mathrm{EC}_{50}$ & 420 & & (Hoberg 1998b) \\
\hline & $\begin{array}{l}\text { Dunaliella } \\
\text { tertiolecta }\end{array}$ & $\mathrm{EC}_{50}$ & 560 & & (Hoberg 1998a) \\
\hline & & $\mathrm{EC}_{50}$ & $1.1 \times 10^{3}$ & & (Gatidou et al. 2007) \\
\hline \multirow[t]{3}{*}{ Microphytes } & Elodea canadensis & $\mathrm{EC}_{50}$ & $1.7 \times 10^{7}-5.2 \times 10^{7}$ & $\begin{array}{l}2,500 \quad- \\
25,300^{\mathrm{d}} \quad-\end{array}$ & (Nystrom et al. 2002) \\
\hline & $\begin{array}{l}\text { Potamogeton } \\
\text { pectinatus }\end{array}$ & $\mathrm{EC}_{50}$ & $1 \times 10^{7}$ & $2,500^{\mathrm{d}}$ & (Nystrom et al. 2002) \\
\hline & $\begin{array}{l}\text { Seriatopora } \\
\text { hystrix }\end{array}$ & $\begin{array}{l}10 \text { hour } \\
\text { Photosynthesis }\end{array}$ & 700 & & (Jones et al. 2003) \\
\hline
\end{tabular}


APPENDIX B. Continued.

\begin{tabular}{|c|c|c|c|c|c|}
\hline Class & Test Organism & Toxicity Index & $\begin{array}{c}\text { Irgarol } \\
\text { EC }_{50}{ }^{\mathrm{a}} \text { or } \mathrm{LC}_{50}^{\mathrm{b}}\end{array}$ & $\begin{array}{c}\text { Irgarol } \\
\text { NOEC }^{\mathrm{c}} \text { or LOEC }\end{array}$ & Reference \\
\hline & Asterionella formosa & 96 day Growth & $>2.53 \times 10^{5}$ & & $\begin{array}{lll}\text { (Berard et } & \text { al. } \\
2003) & & \end{array}$ \\
\hline \multirow[t]{10}{*}{ Phytoplankton } & various species & $\mathrm{EC}_{50}$ & $4.42 \times 10^{3}-6.5 \times 10^{3}$ & $25-647^{\mathrm{d}}$ & $\begin{array}{l}\text { (Nystrom et al. } \\
2002 \text { ) }\end{array}$ \\
\hline & Navicula pelliculosa & $\mathrm{EC}_{50}$ & 136 & & (Hughes 1993) \\
\hline & Skeletonema costatum & $\mathrm{EC}_{50}$ & 386 & & $\begin{array}{l}\text { (Hughes et al. } \\
1993 \text { ) }\end{array}$ \\
\hline & Emiliania huxleyi & 72 hour $\mathrm{EC}_{50}$ & 250 & $100^{\mathrm{d}}$ & $\begin{array}{l}\text { (Devilla et al. } \\
\text { 2005) }\end{array}$ \\
\hline & Navicula forcipata & $\mathrm{EC}_{50}$ & 600 & & $\begin{array}{l}\text { (Gatidou et al. } \\
\text { 2007) }\end{array}$ \\
\hline & Synecochoccus sp. & 72 hour $\mathrm{EC}_{50}$ & 160 & & $\begin{array}{l}\text { (Devilla et al. } \\
\text { 2005) }\end{array}$ \\
\hline & Synecochoccus sp. & 12 day exposure & & $441^{\mathrm{c}} ; 963^{\mathrm{d}}$ & $\begin{array}{l}\text { (Zamora-Ley et al. } \\
\text { 2006) }\end{array}$ \\
\hline & Rhodomonas salina & 7 day exposure & & $350^{c} ; 800^{d}$ & $\begin{array}{l}\text { (Zamora-Ley et al. } \\
\text { 2006) }\end{array}$ \\
\hline & Scrippsiella sp. & 19 day exposure & & $640^{\mathrm{c}} ; 836^{\mathrm{d}}$ & $\begin{array}{l}\text { (Zamora-Ley et al. } \\
\text { 2006) }\end{array}$ \\
\hline & T. pseudonana & 76 hour exposure & 410 & $1,000^{c} ; 100^{d}$ & (Zhang et al. 2008) \\
\hline
\end{tabular}


APPENDIX B. Continued.

\begin{tabular}{|c|c|c|c|c|c|}
\hline Class & Test Organism & Toxicity Index & $\begin{array}{l}\text { Irgarol } \\
\mathrm{EC}_{50}{ }^{\mathrm{a}} \text { or } \mathrm{LC}_{50}{ }^{\mathrm{b}} \\
\end{array}$ & $\begin{array}{l}\text { Irgarol } \\
\text { NOEC }^{c} \text { or LOEC } \\
\end{array}$ & Reference \\
\hline & S. costatum & 76 hour exposure & 290 & $100^{\mathrm{c}} ; 10^{\mathrm{d}}$ & (Zhang et al. 2008) \\
\hline \multirow[t]{2}{*}{ Duckweed } & Lemna gibba & 7 day $\mathrm{EC}_{50}$ & $1.1 \times 10^{7}-1.2 \times 10^{7}$ & & $\begin{array}{l}\text { (Okamura et al. } \\
2000 \mathrm{~b})\end{array}$ \\
\hline & Lemna minor & 7 day $\mathrm{EC}_{50}$ & $7.3 \times 10^{6}-8.9 \times 10^{6}$ & & $\begin{array}{l}\text { (Okamura et al. } \\
2000 b)\end{array}$ \\
\hline Bacteria & Vibrio fischeri & 15 minute $\mathrm{EC}_{50}$ & $5.08 \times 10^{10} \pm 7.8 \times 10^{9}$ & $10 \times 10^{6} \pm 9 \times 10^{6 \mathrm{~d}}$ & $\begin{array}{l}\text { (Fernandez-Alba et } \\
\text { al. 2002) }\end{array}$ \\
\hline \multirow[t]{2}{*}{ Cyanobacterium } & $\begin{array}{l}\text { Chroococcus } \\
\text { minor }\end{array}$ & 76 hour exposure & $7.71 \times 10^{3}$ & $10,000^{c} ; 1000^{d}$ & (Zhang et al. 2008) \\
\hline & & 96 hour exposure & $1 \times 10^{3}$ & $100,000^{\mathrm{c}}$ & (Zhang et al. 2008) \\
\hline \multirow[t]{4}{*}{ Crustacean } & Daphnia magna & 48 hour $\mathrm{EC}_{50}$ & $7.3 \times 10^{9} \pm 1.2 \times 10^{9}$ & $2.4 \times 10^{6} \pm 3 \times 10^{5 \mathrm{~d}}$ & $\begin{array}{l}\text { (Fernandez-Alba } \\
\text { al. 2002) }\end{array}$ \\
\hline & Daphnia magna & 48 hour $\mathrm{EC}_{50}$ & $6.7 \times 10^{9} \pm 10 \times 10^{9}$ & & $\begin{array}{l}\text { (Fernandez-Alba } \\
\text { al. 2002) }\end{array}$ \\
\hline & Daphnia pulex & 24 hour $\mathrm{LC}_{50}$ & $5.1 \times 10^{6}-6.3 \times 10^{6}$ & & $\begin{array}{l}\text { (Fernandez-Alba } e \\
\text { al. 2002) }\end{array}$ \\
\hline & $\begin{array}{l}\text { Thamnocepharus } \\
\text { platvurus }\end{array}$ & 24 hour $\mathrm{LC}_{50}$ & $1.1 \times 10^{6}-13 \times 10^{6}$ & & $\begin{array}{l}\text { (Fernandez-Alba } \\
\text { al. 2002) }\end{array}$ \\
\hline
\end{tabular}

${ }^{\mathrm{a}} \mathrm{EC}_{50}=$ effect concentration $\left(\mathrm{ng} \mathrm{L}^{-1}\right) \quad{ }^{\mathrm{c}} \operatorname{NOEC}\left(\mathrm{ng} \mathrm{L}^{-1}\right)=$ no observed effect concentration

${ }^{\mathrm{b}} \mathrm{LC}_{50}=$ lethal concentration $\left(\mathrm{ng} \mathrm{L}^{-1}\right) \quad{ }^{\mathrm{d}} \mathrm{LOEC}\left(\mathrm{ng} \mathrm{L}{ }^{-1}\right)=$ lowest observable effect concentration 
APPENDIX B: Continued.

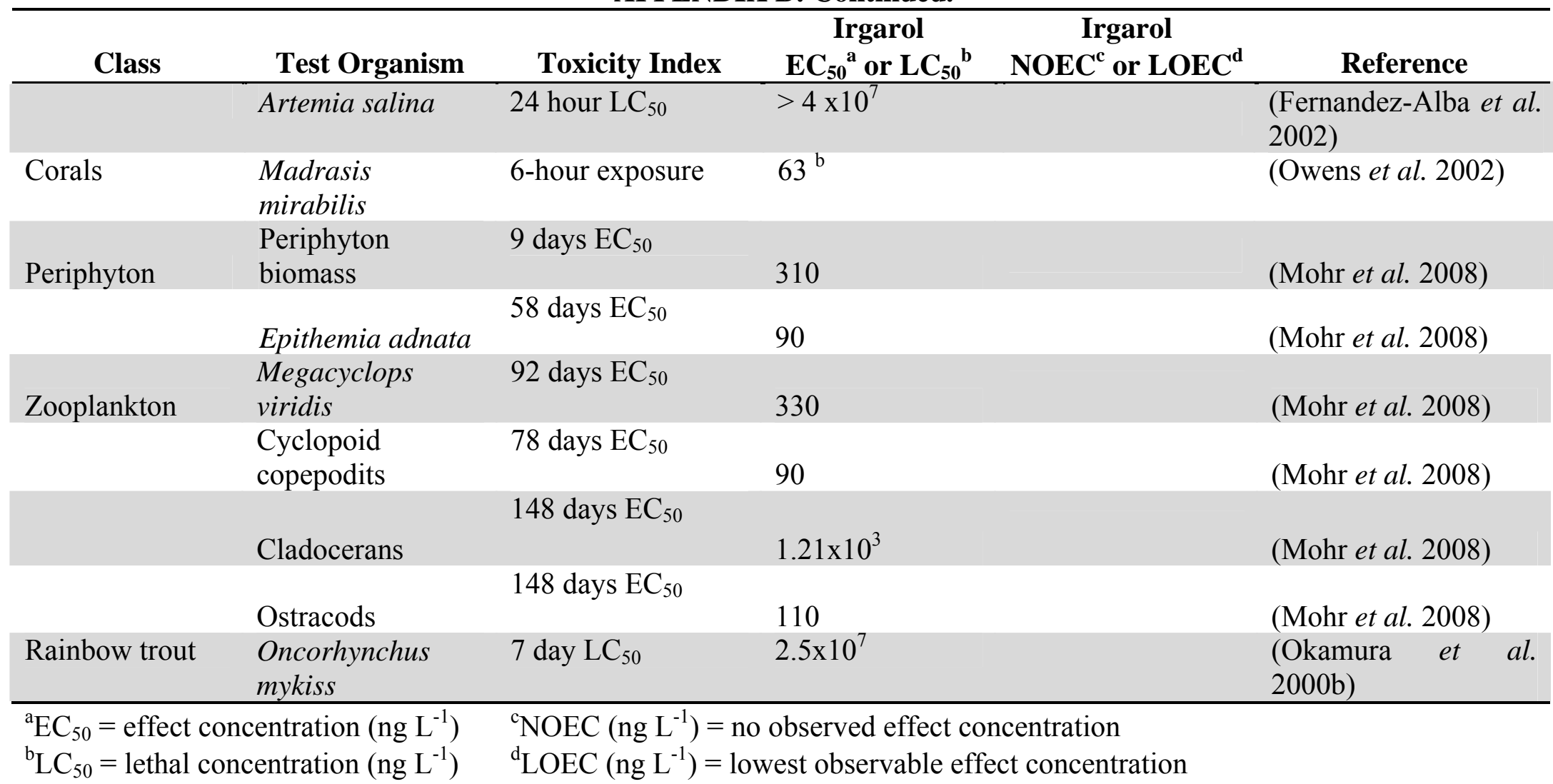


APPENDIX C. Concentrations of herbicides in Coconut Grove.

\begin{tabular}{|c|c|c|c|c|c|}
\hline Sampling Site & Date & Irgarol (ng/L) & M1 (ng/L) & M3 (ng/L) & Atrazine (ng/L) \\
\hline CG01 & $2 / 4 / 08$ & 33.2 & 25.1 & 0.00 & 10.6 \\
\hline CG02 & $2 / 4 / 08$ & 34.8 & 17.0 & 0.00 & 5.94 \\
\hline CG03 & $2 / 4 / 08$ & 19.7 & 34.7 & 0.00 & 4.70 \\
\hline CG04 & $2 / 4 / 08$ & 54.0 & 22.2 & 0.00 & 5.90 \\
\hline CG05 & $2 / 4 / 08$ & 65.9 & 29.3 & 0.00 & 9.08 \\
\hline CG06 & $2 / 4 / 08$ & 33.4 & 14.0 & 0.00 & 5.15 \\
\hline CG07 & $2 / 4 / 08$ & 15.5 & 14.9 & 0.00 & 9.04 \\
\hline CG08 & $2 / 4 / 08$ & 20.3 & 11.3 & 2.67 & 6.43 \\
\hline CG01 & $5 / 10 / 07$ & 45.9 & 29.0 & 3.10 & 6.92 \\
\hline CG02 & $5 / 10 / 07$ & 31.2 & 15.40 & 1.19 & 7.18 \\
\hline CG03 & $5 / 10 / 07$ & 33.7 & 19.30 & 0.00 & 5.82 \\
\hline CG04 & $5 / 10 / 07$ & 86.3 & 22.90 & 0.00 & 7.67 \\
\hline CG05 & $5 / 10 / 07$ & 64.0 & 25.80 & 0.00 & 8.37 \\
\hline CG06 & $5 / 10 / 07$ & 30.8 & 22.90 & 0.00 & 5.52 \\
\hline CG07 & $5 / 10 / 07$ & 28.4 & 10.20 & 2.37 & 6.27 \\
\hline CG08 & $5 / 10 / 07$ & 71.0 & 23.00 & 0.00 & 7.43 \\
\hline CG01 & $8 / 21 / 06$ & 30.4 & 15.4 & 0.00 & 1.79 \\
\hline CG02 & $8 / 21 / 06$ & 27.9 & 13.6 & 0.00 & 2.10 \\
\hline CG03 & $8 / 21 / 06$ & 32.6 & 16.2 & 0.00 & 1.79 \\
\hline CG04 & $8 / 21 / 06$ & 57.7 & 20.8 & 0.00 & 1.69 \\
\hline CG05 & $8 / 21 / 06$ & 61.0 & 22.5 & 0.00 & 1.64 \\
\hline CG06 & $8 / 21 / 06$ & 56.8 & 23.7 & 0.00 & 2.05 \\
\hline CG07 & $8 / 21 / 06$ & 10.6 & 5.54 & 0.00 & 1.88 \\
\hline CG08 & $8 / 21 / 06$ & 18.8 & 9.14 & 0.00 & 1.62 \\
\hline
\end{tabular}


APPENDIX D. Concentrations of herbicides in Key Largo Harbor.

\begin{tabular}{|c|c|c|c|c|c|}
\hline Sampling Site & Date & Irgarol (ng/L) & M1 (ng/L) & M3 (ng/L) & Atrazine (ng/L) \\
\hline KLH01 & $1 / 25 / 08$ & 102 & 22.2 & 0.00 & 0.00 \\
\hline KLH02 & $1 / 25 / 08$ & 94.9 & 17.7 & 0.00 & 0.00 \\
\hline KLH03 & $1 / 25 / 08$ & 20.3 & 6.14 & 0.00 & 0.00 \\
\hline KLH04 & $1 / 25 / 08$ & 10.3 & 4.02 & 0.00 & 0.00 \\
\hline KLH05 & $1 / 25 / 08$ & 9.68 & 3.64 & 0.00 & 0.00 \\
\hline KLH06 & $1 / 25 / 08$ & 7.04 & 1.99 & 0.00 & 0.00 \\
\hline KLH07 & $1 / 25 / 08$ & 8.86 & 4.63 & 0.00 & 0.00 \\
\hline KLH08 & $1 / 25 / 08$ & 25.4 & 7.30 & 0.00 & 0.00 \\
\hline KLH01 & $6 / 6 / 07$ & 241 & 50.0 & 0.00 & 2.52 \\
\hline KLH02 & $6 / 6 / 07$ & 117 & 31.1 & 0.00 & 2.03 \\
\hline KLH03 & $6 / 6 / 07$ & 28.7 & 10.7 & 0.00 & 1.30 \\
\hline KLH04 & $6 / 6 / 07$ & 12.2 & 2.90 & 0.00 & 0.00 \\
\hline KLH05 & $6 / 6 / 07$ & 8.20 & 3.10 & 0.00 & 0.00 \\
\hline KLH06 & $6 / 6 / 07$ & 9.50 & 0.00 & 0.00 & 0.00 \\
\hline KLH07 & $6 / 6 / 07$ & 5.70 & 0.00 & 0.00 & 0.00 \\
\hline KLH01 & $2 / 5 / 04$ & 86.1 & 12.6 & 0.00 & 2.22 \\
\hline KLH02 & $2 / 5 / 04$ & 135 & 27.0 & 0.00 & 0.00 \\
\hline KLH03 & $2 / 5 / 04$ & 175 & 36.9 & 0.00 & 1.75 \\
\hline KLH04 & $2 / 5 / 04$ & 178 & 35.8 & 0.00 & 1.89 \\
\hline KLH05 & $2 / 5 / 04$ & 289 & 33.8 & 0.00 & 1.88 \\
\hline KLH06 & $2 / 5 / 04$ & 450 & 60.1 & 0.00 & 1.99 \\
\hline KLH07 & $2 / 5 / 04$ & 62.4 & 11.1 & 0.00 & 2.34 \\
\hline KLH08 & $2 / 5 / 04$ & 78.4 & 21.0 & 0.00 & 1.74 \\
\hline KLH01 & $6 / 14 / 04$ & 68.7 & 19.1 & 0.00 & 0.00 \\
\hline KLH02 & $6 / 14 / 04$ & 159 & 47.5 & 0.00 & 3.24 \\
\hline
\end{tabular}


APPENDIX D. Continued.

\begin{tabular}{l|cc|c|c|c}
\hline \multicolumn{1}{c|}{ Sampling Site } & Date & Irgarol (ng/L) & M1 (ng/L) & M3 (ng/L) & Atrazine (ng/L) \\
\hline KLH03 & $6 / 14 / 04$ & 213 & 70.8 & 0.00 & 2.69 \\
KLH04 & $6 / 14 / 04$ & 172 & 57.5 & 0.00 & 0.00 \\
KLH05 & $6 / 14 / 04$ & 189 & 66.2 & 0.00 & 0.00 \\
KLH06 & $6 / 14 / 04$ & 136 & 38.5 & 0.00 & 0.00 \\
\hline KLH01 & $4 / 29 / 04$ & 266 & 74.8 & 0.00 & 9.50 \\
KLH02 & $4 / 29 / 04$ & 90.2 & 35.0 & 0.00 & 6.92 \\
KLH03 & $4 / 29 / 04$ & 95.6 & 30.3 & 0.00 & 6.77 \\
KLH04 & $4 / 29 / 04$ & 89.4 & 33.4 & 0.00 & 8.86 \\
KLH05 & $4 / 29 / 04$ & 81.0 & 26.0 & 0.00 & 6.90 \\
KLH06 & $4 / 29 / 04$ & 7.00 & 0.00 & 0.00 & \\
\hline
\end{tabular}


APPENDIX E. Concentrations of herbicides in Miami River.

\begin{tabular}{|c|c|c|c|c|c|}
\hline Sampling Site & Date & Irgarol (ng/L) & M1 (ng/L) & M3 (ng/L) & Atrazine (ng/L) \\
\hline MR95 & $5 / 20 / 08$ & 52.1 & 26.7 & 0.00 & 18.8 \\
\hline MRBP & $5 / 20 / 08$ & 28.4 & 19.4 & 0.00 & 19.4 \\
\hline MRBY & $5 / 20 / 08$ & 12.0 & 12.9 & 0.00 & 11.5 \\
\hline MRCP & $5 / 20 / 08$ & 20.8 & 12.3 & 0.00 & 10.6 \\
\hline MRMS & $5 / 20 / 08$ & 41.9 & 35.6 & 0.00 & 13.8 \\
\hline MRNS & $5 / 20 / 08$ & 39.2 & 17.8 & 0.00 & 13.4 \\
\hline MRSF & $5 / 20 / 08$ & 33.7 & 23.6 & 0.00 & 21.0 \\
\hline MRYC & $5 / 20 / 08$ & 40.0 & 40.1 & 0.00 & 18.2 \\
\hline
\end{tabular}


APPENDIX F. BCFs of SAVS.

\begin{tabular}{|c|c|c|c|c|c|c|}
\hline Year & Location & SAV & Irgarol BCF & M1 BCF & Irgarol (ng/g DW) & M1 (ng/g DW) \\
\hline $5 / 10 / 07$ & CG02 & Syringodium & 6026 & 786 & 188 & 12.1 \\
\hline $5 / 10 / 07$ & CG03 & Syringodium & 11109 & 1393 & 374 & 26.9 \\
\hline $5 / 10 / 07$ & CG07 & Syringodium & 4055 & 768 & 115 & 7.83 \\
\hline $2 / 4 / 08$ & CG01 & Syringodium & 4692 & & 156 & \\
\hline $2 / 4 / 08$ & CG07 & Syringodium & 8163 & & 127 & \\
\hline $5 / 10 / 07$ & CG01 & Thalassia & 501 & & 23.0 & \\
\hline $5 / 10 / 07$ & CG02 & Thalassia & 2234 & & 69.7 & \\
\hline $5 / 10 / 07$ & CG03 & Thalassia & 8101 & & 273 & \\
\hline $5 / 10 / 07$ & CG04 & Thalassia & 1973 & 441 & 170 & 10.1 \\
\hline $5 / 10 / 07$ & CG05 & Thalassia & 438 & & 28.0 & \\
\hline $5 / 10 / 07$ & CG06 & Thalassia & 10364 & & 319 & \\
\hline $5 / 10 / 07$ & CG07 & Thalassia & 0 & & & \\
\hline $5 / 10 / 07$ & CG08 & Thalassia & 810 & & 57.5 & \\
\hline $6 / 6 / 07$ & KLH05 & Thalassia & 755 & & 6.19 & \\
\hline $6 / 6 / 07$ & KLH06 & Thalassia & 0 & & & \\
\hline $6 / 6 / 07$ & KLH07 & Thalassia & 4934 & & 28.1 & \\
\hline $5 / 10 / 07$ & CG04 & Thalassia & 769 & & 66.4 & \\
\hline $5 / 10 / 07$ & CG07 & Thalassia & 208 & & 5.90 & \\
\hline $5 / 10 / 07$ & CG06 & Thalassia & 11889 & & 366 & \\
\hline $5 / 10 / 07$ & CG07 & Thalassia & 373 & & 10.6 & \\
\hline $6 / 6 / 07$ & KLH08 & Thalassia & 0 & & & \\
\hline $2 / 4 / 08$ & CG01 & Thalassia & 662 & & 22.0 & \\
\hline $2 / 4 / 08$ & CG02 & Thalassia & 938 & & 32.6 & \\
\hline $2 / 4 / 08$ & CG03 & Thalassia & 1694 & & 33.4 & \\
\hline $2 / 4 / 08$ & CG04 & Thalassia & 249 & & 13.4 & \\
\hline $2 / 4 / 08$ & CG05 & Thalassia & 704 & & 46.4 & \\
\hline
\end{tabular}


APPENDIX F. Continued.

\begin{tabular}{|c|c|c|c|c|c|c|}
\hline $2 / 4 / 08$ & CG06 & Thalassia & 185 & & 6.18 & \\
\hline $2 / 4 / 08$ & CG07 & Thalassia & 3036 & & 47.1 & \\
\hline $2 / 4 / 08$ & CG08 & Thalassia & 268 & & 5.44 & \\
\hline $1 / 25 / 08$ & KLH05 & Thalassia & 1314 & & 12.7 & \\
\hline $1 / 25 / 08$ & KLH06 & Thalassia & 5608 & & 39.3 & \\
\hline $1 / 25 / 08$ & KLH07 & Thalassia & 1977 & & 17.6 & \\
\hline $1 / 25 / 08$ & KLH08 & Thalassia & 693 & & 34.7 & \\
\hline $2 / 4 / 08$ & CG04 & Thalassia & 520 & & 26.3 & \\
\hline $2 / 4 / 08$ & CG04 & Thalassia & 347 & & 19.2 & \\
\hline $2 / 4 / 08$ & CG04 & Thalassia & 1061 & & 57.3 & \\
\hline $2 / 4 / 08$ & $\mathrm{CG04}$ & Thalassia & 880 & & 46.0 & \\
\hline $5 / 10 / 07$ & CG07 & Anadyomene & 258 & & 7.33 & \\
\hline $5 / 10 / 07$ & CG01 & Halodule & 21634 & 3595 & 993 & 104 \\
\hline $5 / 10 / 07$ & CG02 & Halodule & 7917 & & 247 & \\
\hline $5 / 10 / 07$ & CG04 & Halodule & 3917 & 697 & 338 & 16.0 \\
\hline $5 / 10 / 07$ & CG06 & Halodule & 11311 & & 348 & \\
\hline $5 / 10 / 07$ & CG07 & Halodule & 7694 & 273 & 219 & 6.25 \\
\hline $5 / 10 / 07$ & CG08 & Halodule & 1650 & & 117 & \\
\hline $6 / 6 / 07$ & KLH05 & Halodule & 0 & & & \\
\hline $5 / 10 / 07$ & CG04 & Halodule & 1372 & 502 & 118 & 11.5 \\
\hline $5 / 10 / 07$ & CG07 & Halodule & 942 & & 26.7 & \\
\hline $5 / 10 / 07$ & CG06 & Halodule & 2512 & 204 & 77.4 & 4.68 \\
\hline $2 / 4 / 08$ & CG02 & Halodule & 9601 & & 334 & \\
\hline $2 / 4 / 08$ & CG04 & Halodule & 6477 & & 350 & \\
\hline $2 / 4 / 08$ & CG05 & Halodule & 1298 & & 85.5 & \\
\hline $2 / 4 / 08$ & CG06 & Halodule & 5111 & & 171 & \\
\hline $2 / 4 / 08$ & CG08 & Halodule & 3460 & & 70.2 & \\
\hline
\end{tabular}


APPENDIX F. Continued.

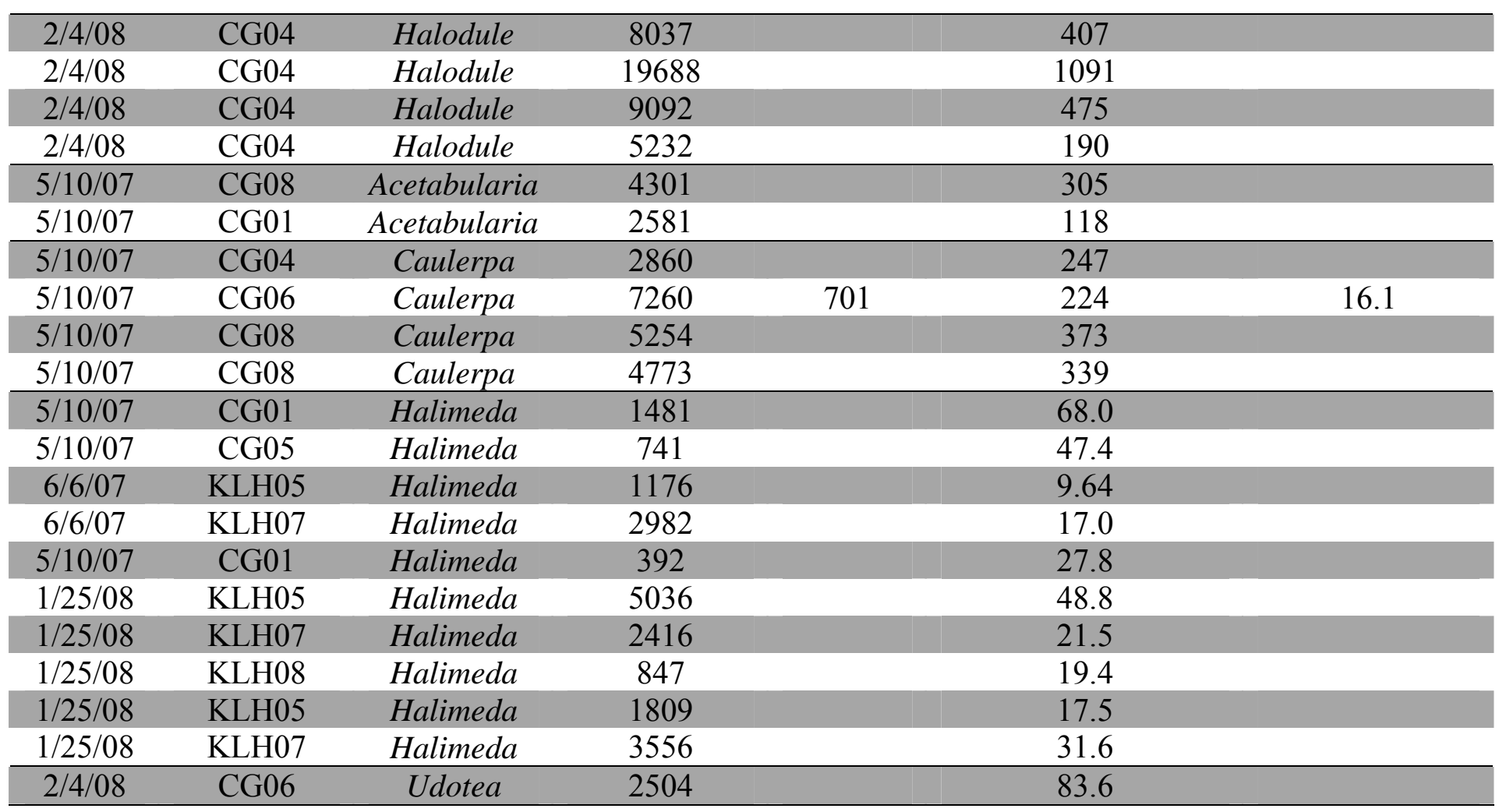

